\title{
Ligand-Controlled Regiodivergent Hydrosilylation of Conjugated Dienes Catalyzed by Mono(phosphine)palladium(0) Complexes
}

\author{
Nobuyuki Komine*, Tatsuo Mitsui, Shu Kikuchi, Masafumi Hirano \\ Department of Applied Chemistry, Graduate School of Engineering, Tokyo University of \\ Agriculture and Technology, 2-24-16 Nakacho, Koganei, Tokyo 184-8588, Japan.
}

\section{Table of Contents}




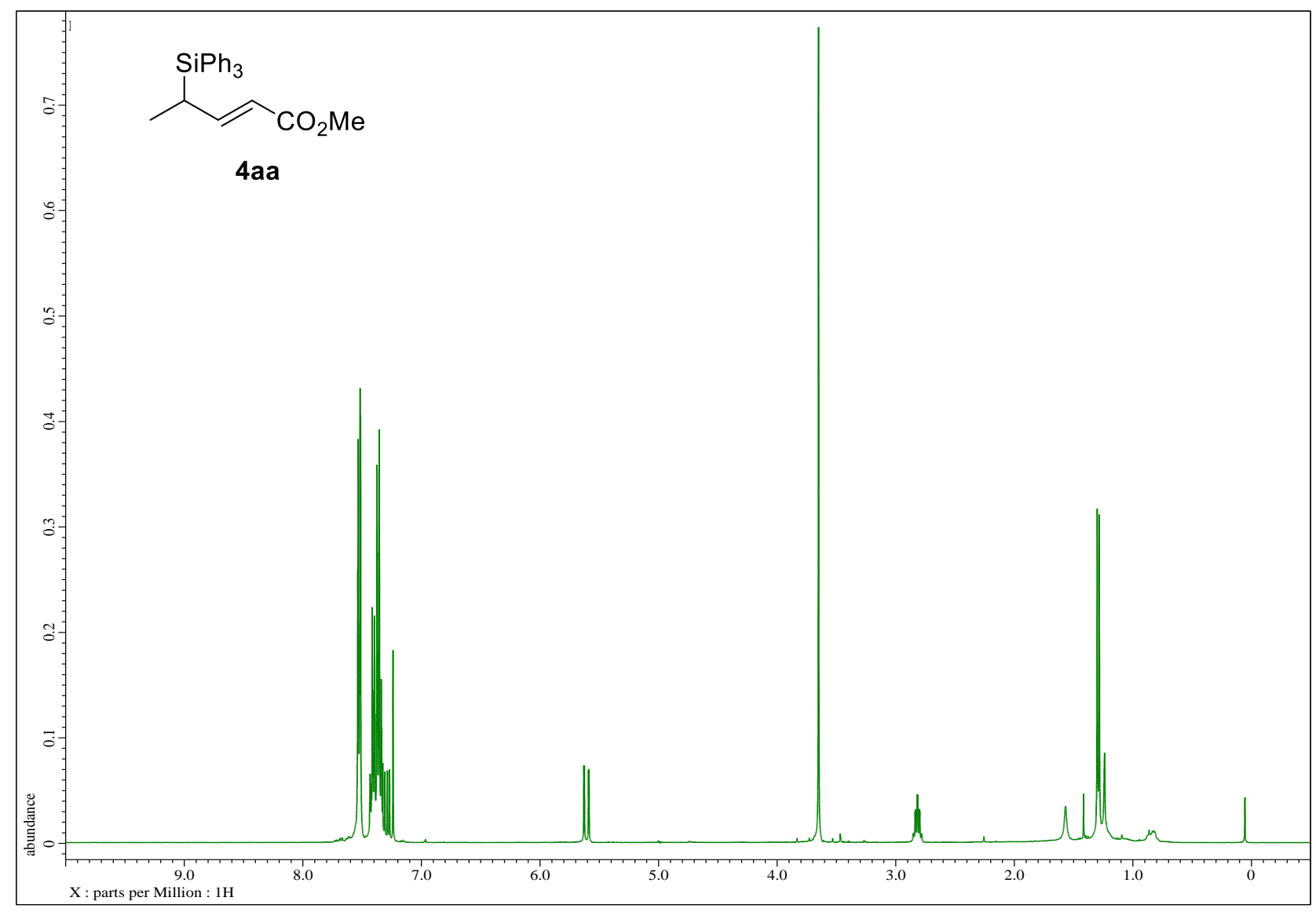

Figure S1. ${ }^{1} \mathrm{H}$ NMR spectra of methyl (E)-4-(triphenylsilyl)pent-2-enoate (4aa) in $\mathrm{CDCl}_{3}$

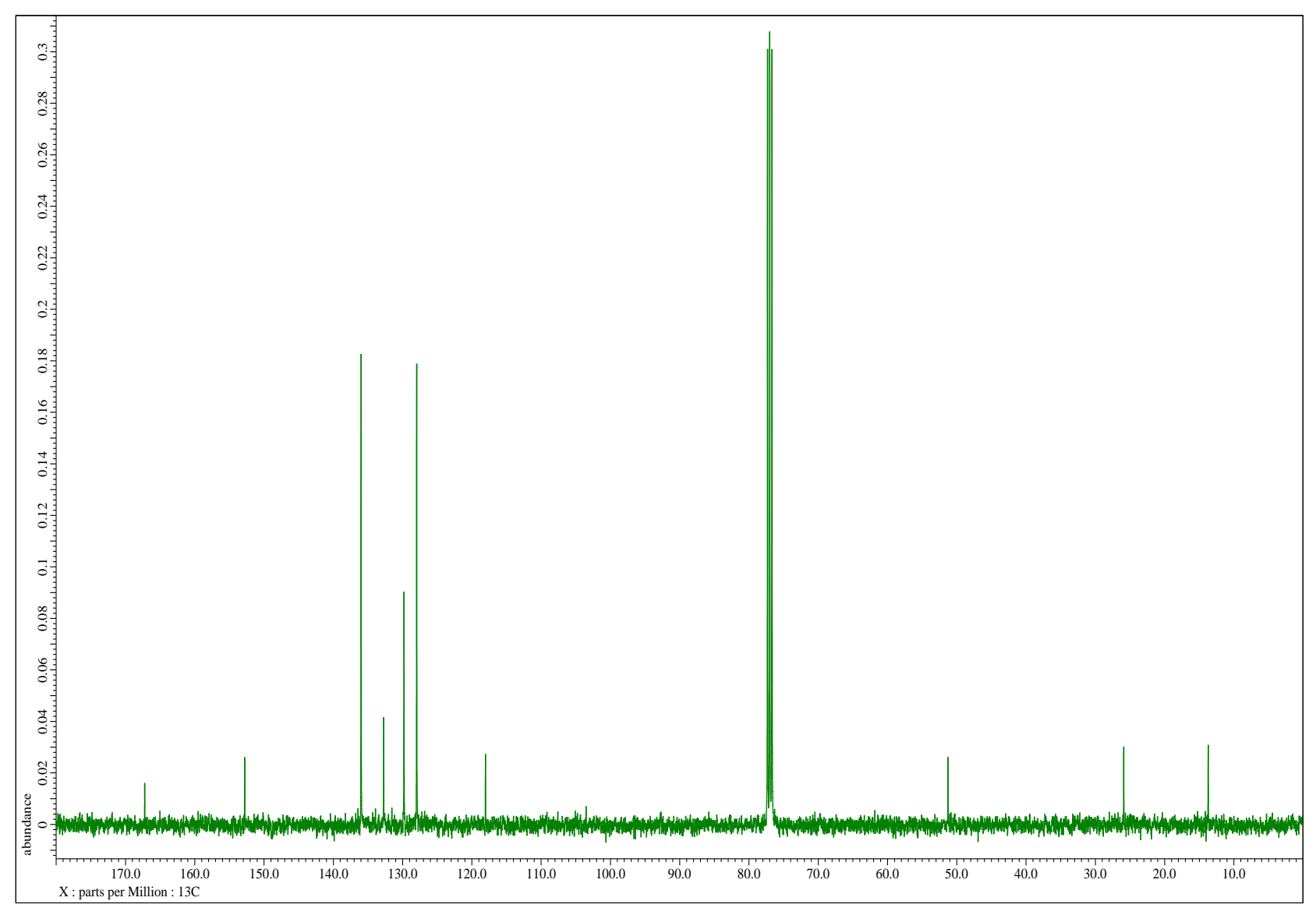

Figure S2. ${ }^{13} \mathrm{C}\left\{{ }^{1} \mathrm{H}\right\}$ NMR spectrum of methyl $(E)$-4-(triphenylsilyl)pent-2-enoate (4aa) in $\mathrm{CDCl}_{3}$ 


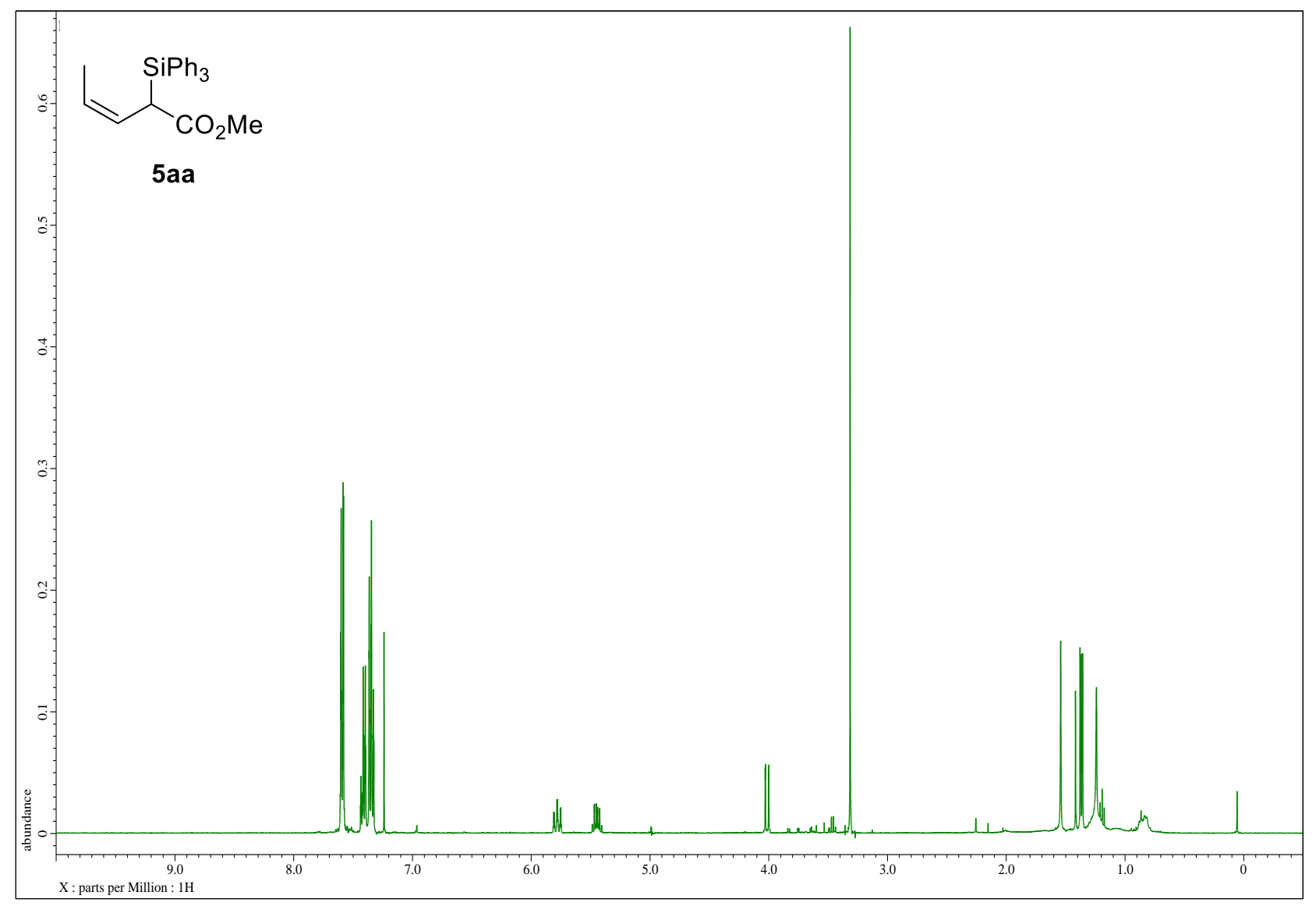

Figure S3. ${ }^{1} \mathrm{H}$ NMR spectra of methyl (Z)-2-(triphenylsilyl)pent-3-enoate (5aa) in $\mathrm{CDCl}_{3}$

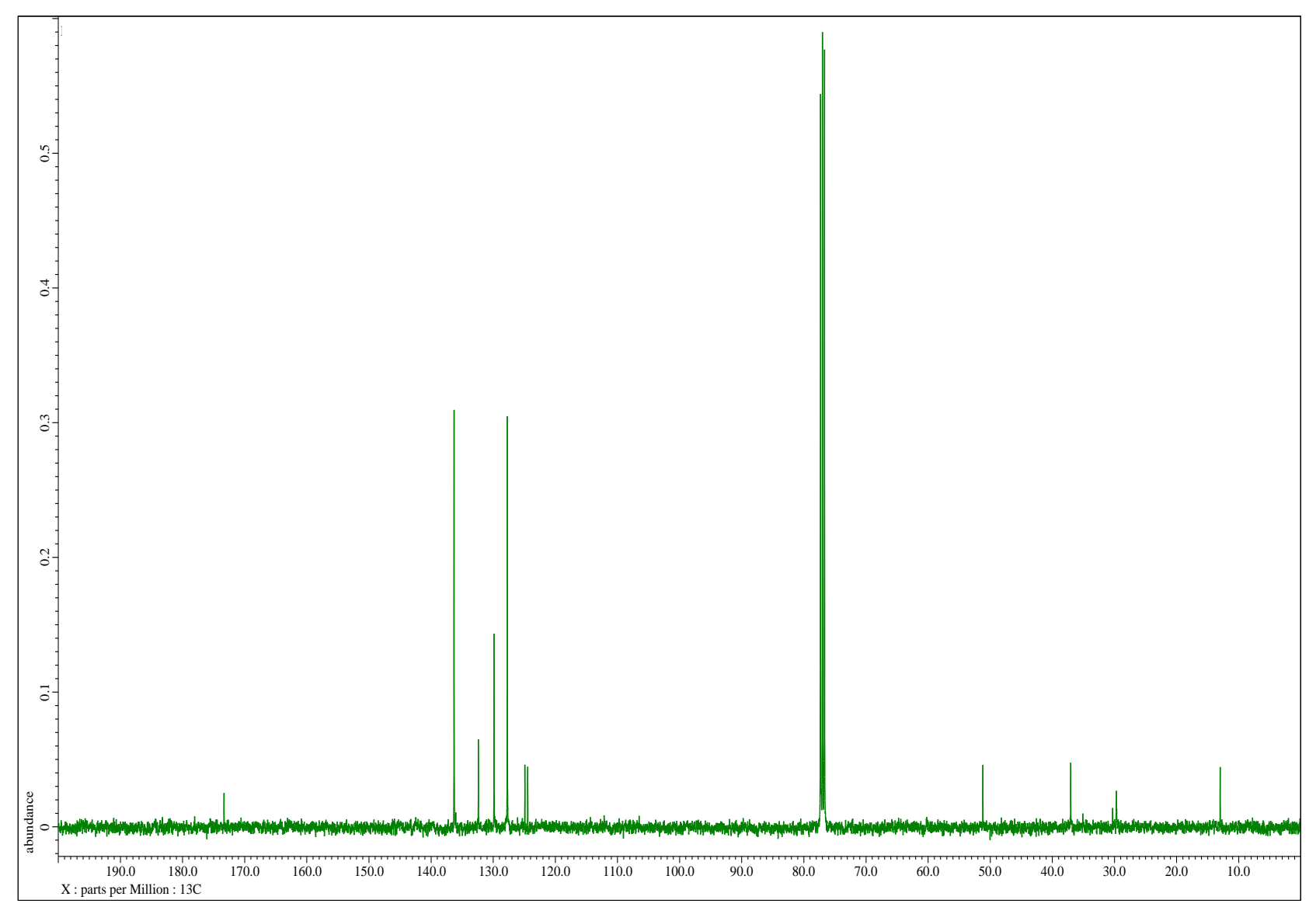

Figure S4. ${ }^{13} \mathrm{C}\left\{{ }^{1} \mathrm{H}\right\}$ NMR spectra of methyl (Z)-2-(triphenylsilyl)pent-3-enoate (5aa) in $\mathrm{CDCl}_{3}$ 


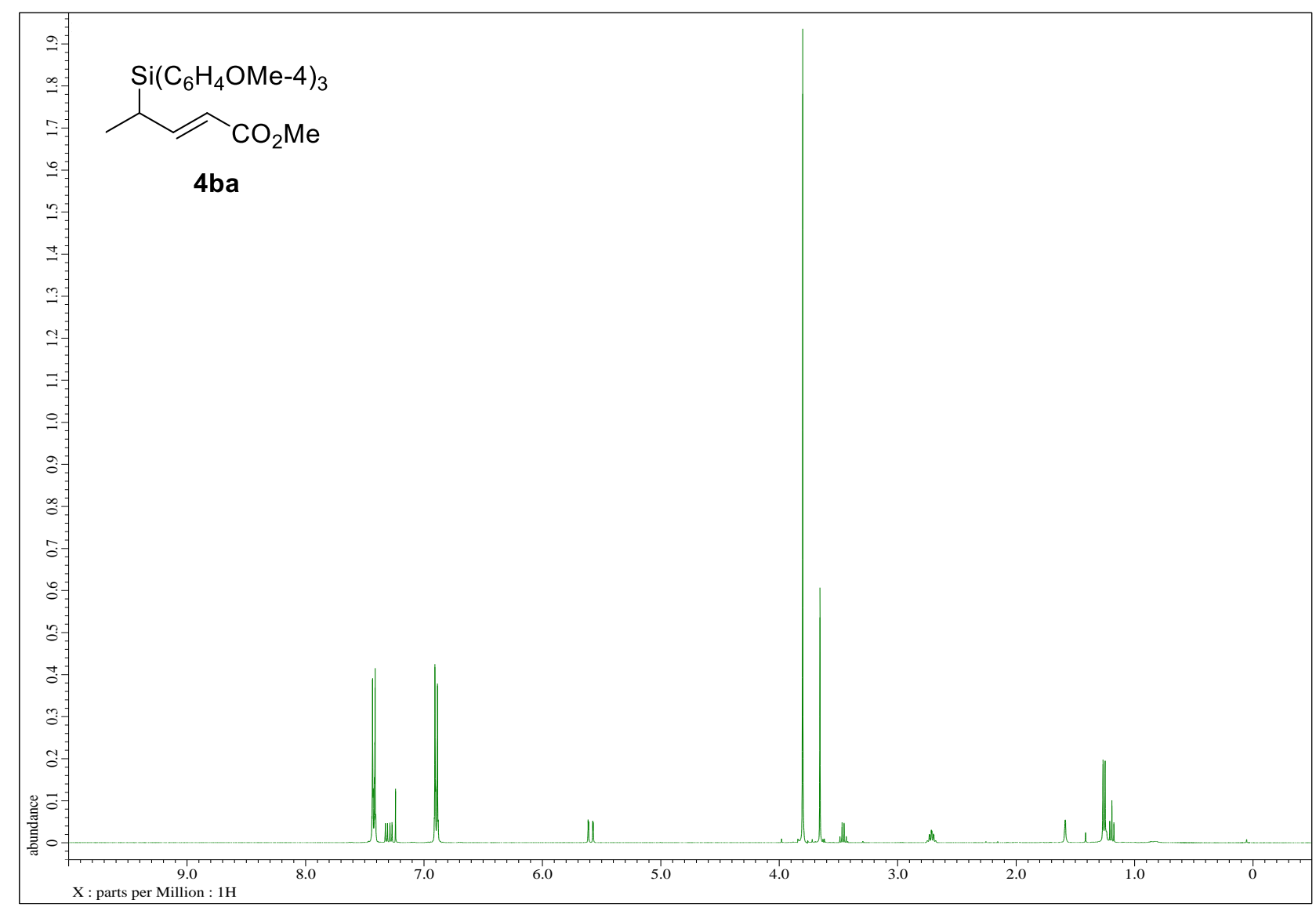

Figure S5. ${ }^{1} \mathrm{H}$ NMR spectrum of methyl (E)-4-(tris(4-methoxyphenyl)silyl)pent-2-enoate (4ba) in $\mathrm{CDCl}_{3}$

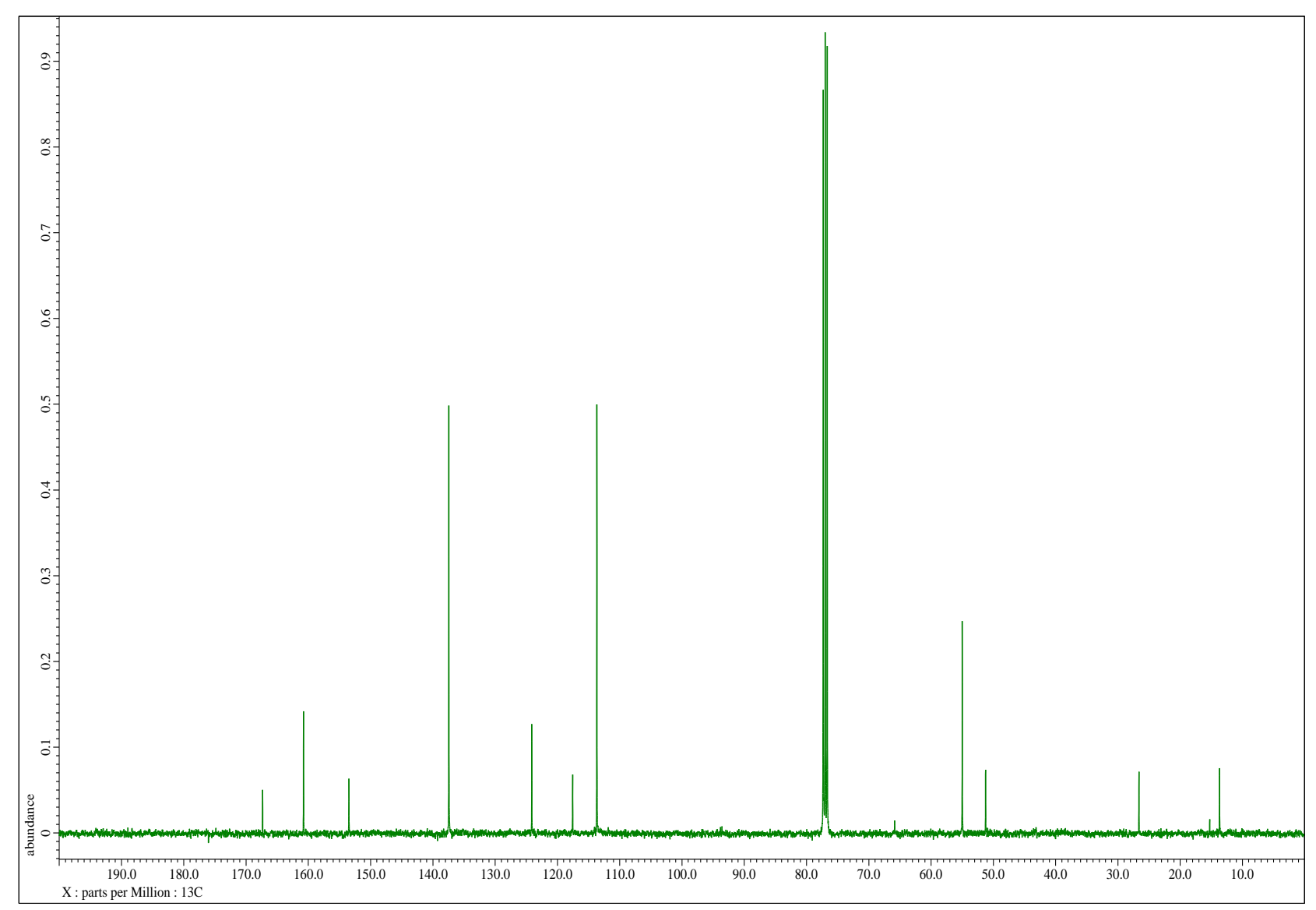

Figure S6. ${ }^{13} \mathrm{C}\left\{{ }^{1} \mathrm{H}\right\}$ NMR spectrum of methyl $(E)$-4-(tris(4-methoxyphenyl)silyl)pent-2-enoate (4ba) in $\mathrm{CDCl}_{3}$ 


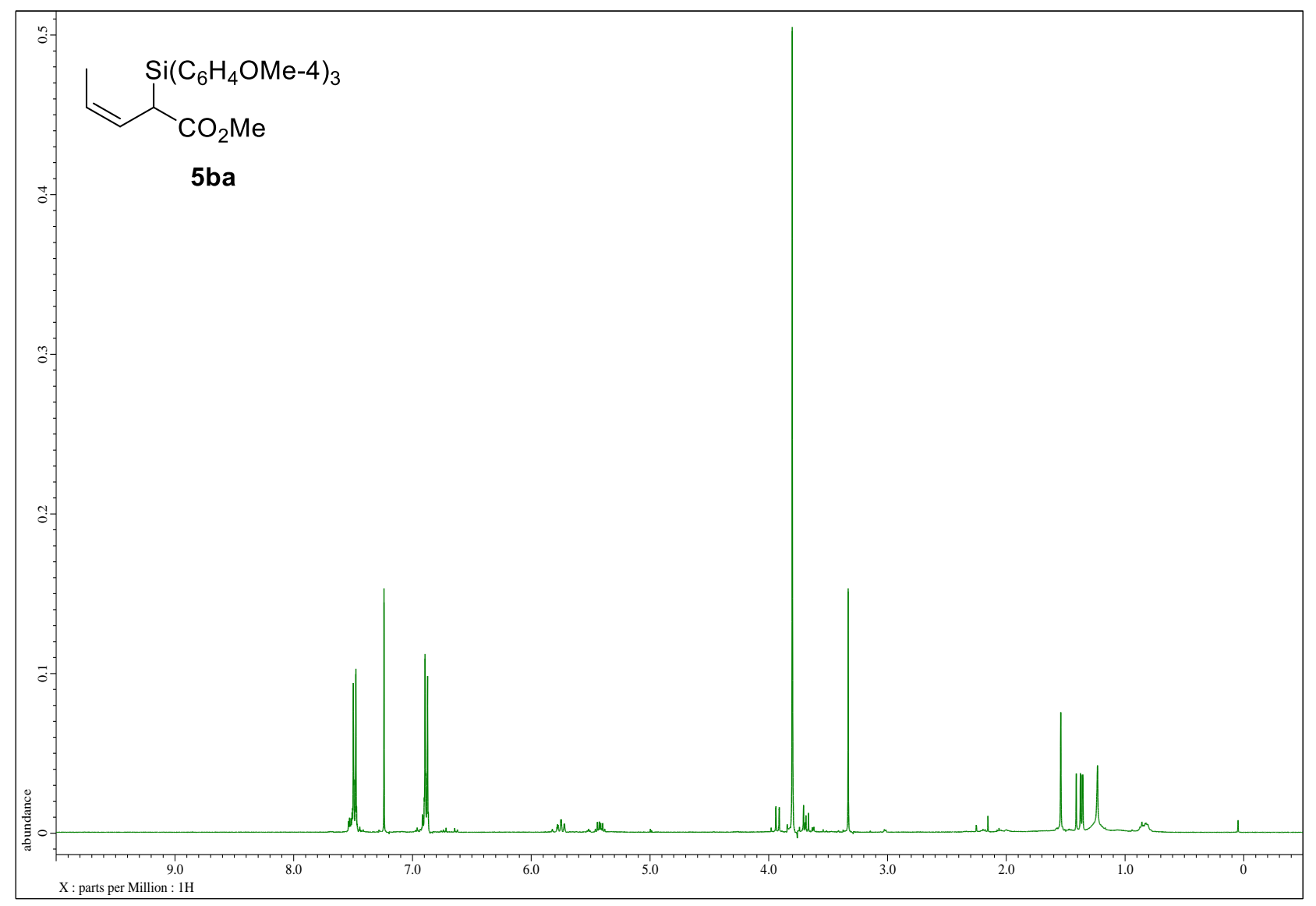

Figure S7. ${ }^{1} \mathrm{H}$ NMR spectrum of methyl (Z)-2-(tris(4-methoxyphenyl)silyl)pent-3-enoate (5ba) in $\mathrm{CDCl}_{3}$

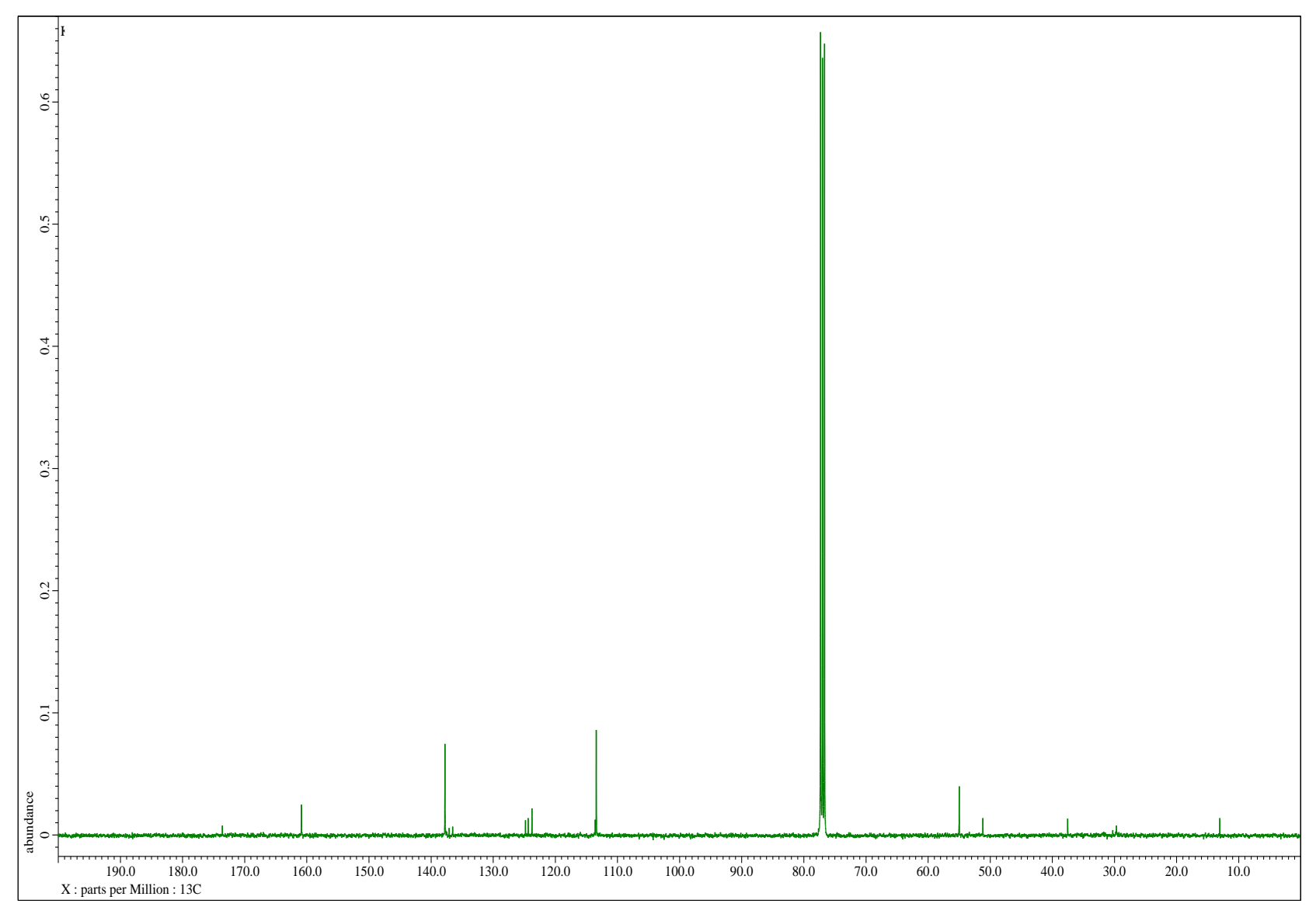

Figure S8. ${ }^{13} \mathrm{C}\left\{{ }^{1} \mathrm{H}\right\}$ NMR spectrum of methyl (Z)-2-(tris(4-methoxyphenyl)silyl)pent-3-enoate (5ba) in $\mathrm{CDCl}_{3}$ 


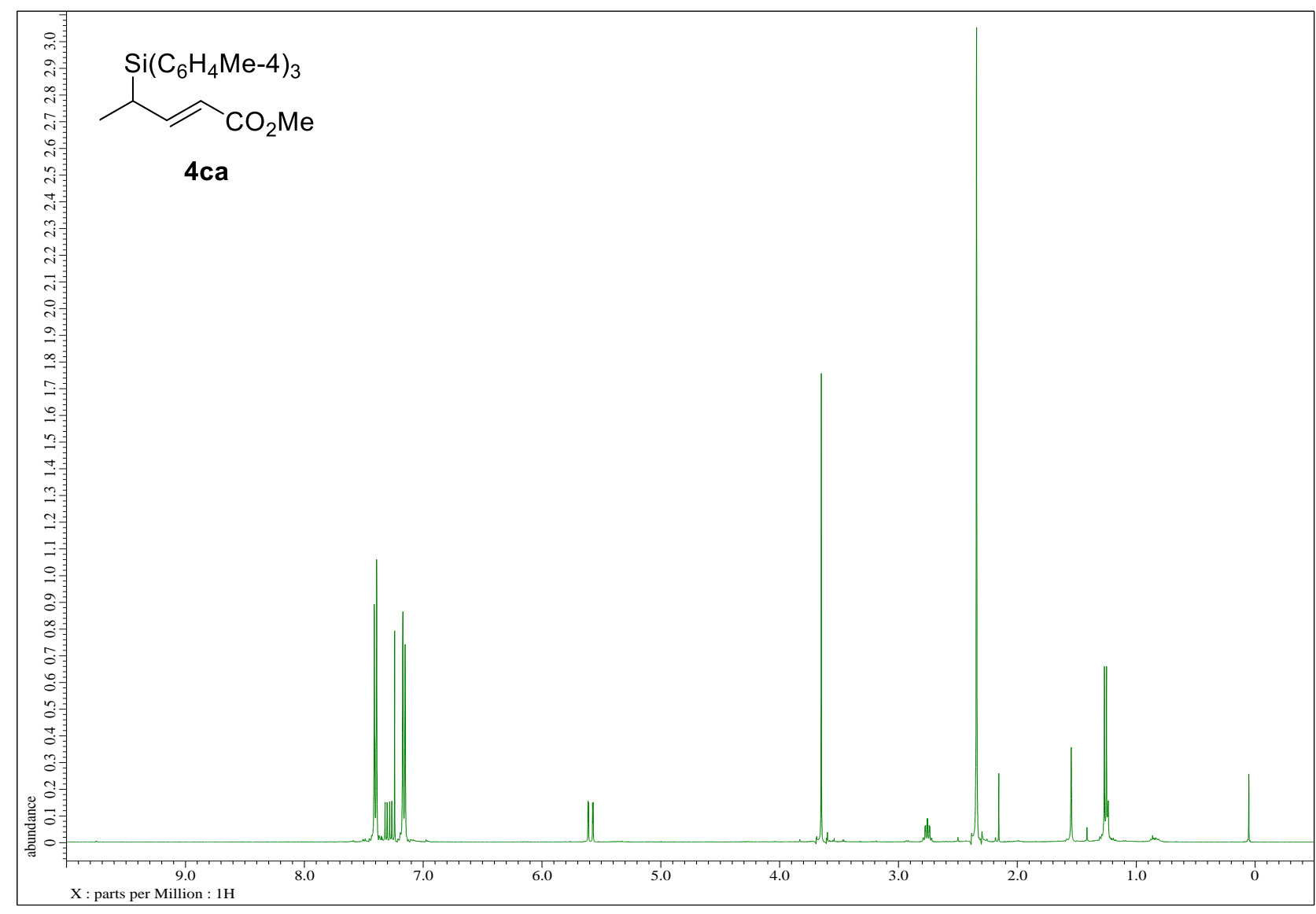

Figure S9. ${ }^{1} \mathrm{H}$ NMR spectrum of methyl (E)-4-(tri-p-tolylsilyl)pent-2-enoate (4ca) in $\mathrm{CDCl}_{3}$

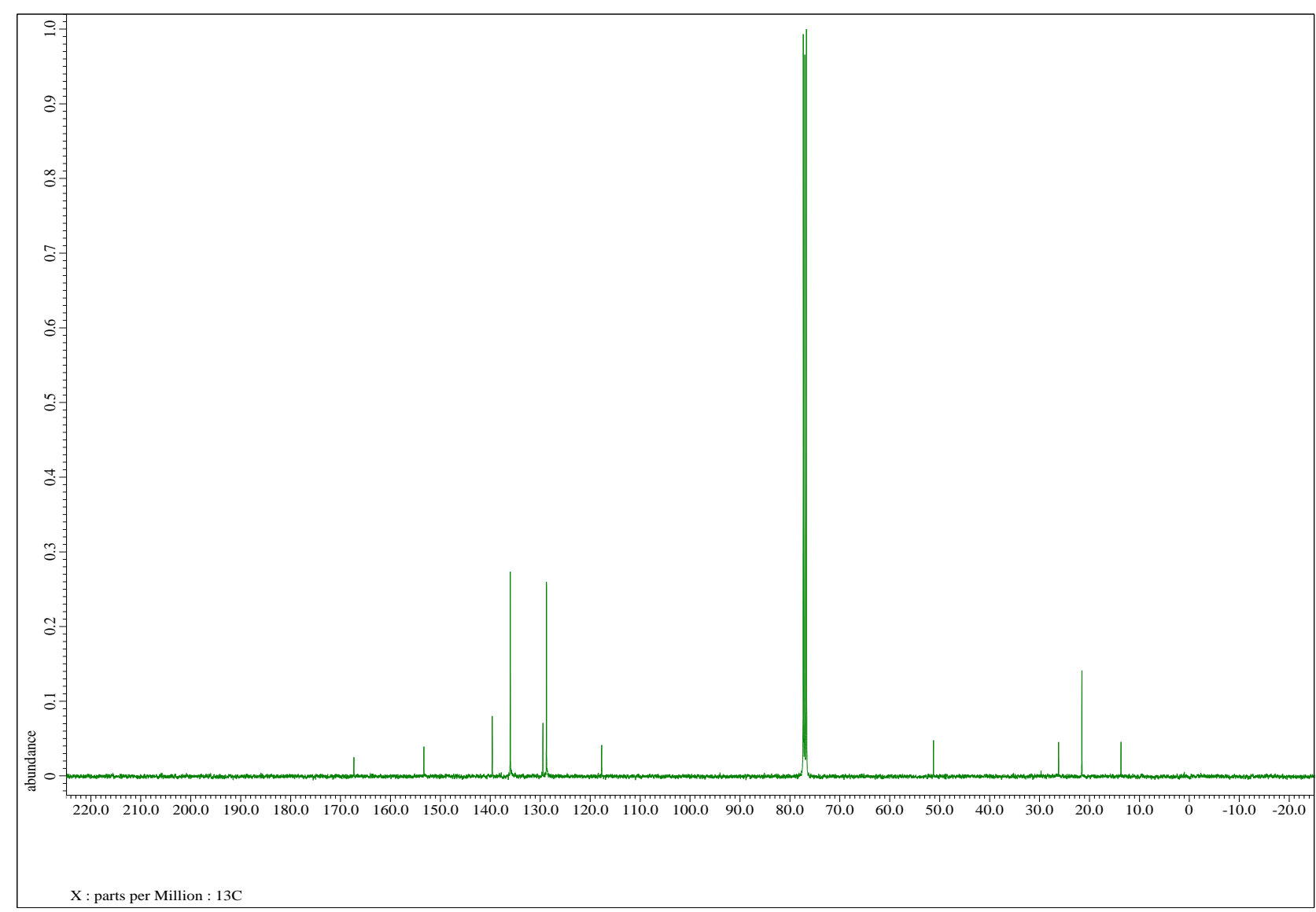

Figure S10. ${ }^{13} \mathrm{C}\left\{{ }^{1} \mathrm{H}\right\}$ NMR spectrum of methyl (E)-4-(tri-p-tolylsilyl)pent-2-enoate (4ca) in $\mathrm{CDCl}_{3}$ 


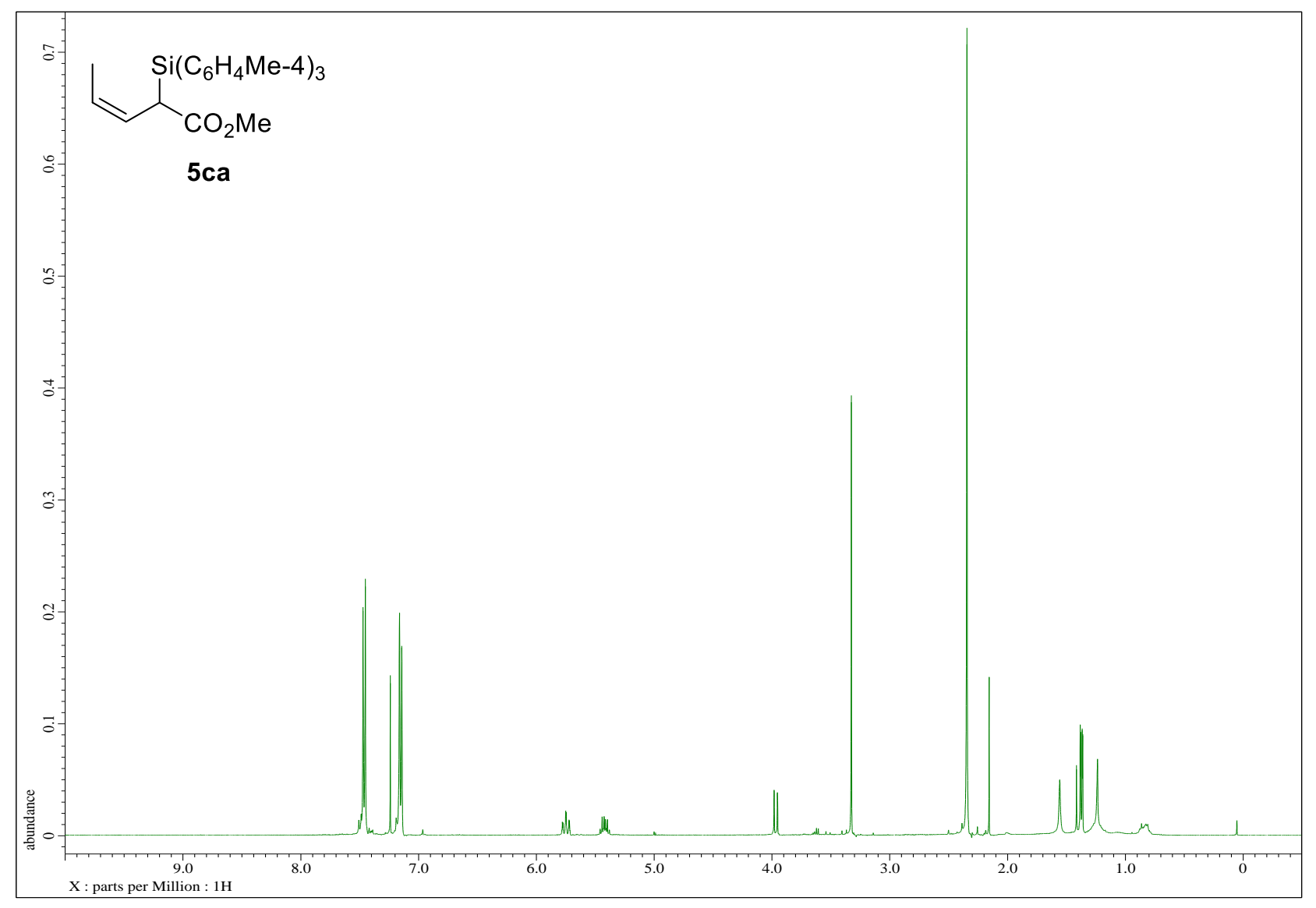

Figure S11. ${ }^{1} \mathrm{H}$ NMR spectrum of methyl (Z)-2-(tri-p-tolylsilyl)pent-3-enoate (5ca) in $\mathrm{CDCl}_{3}$

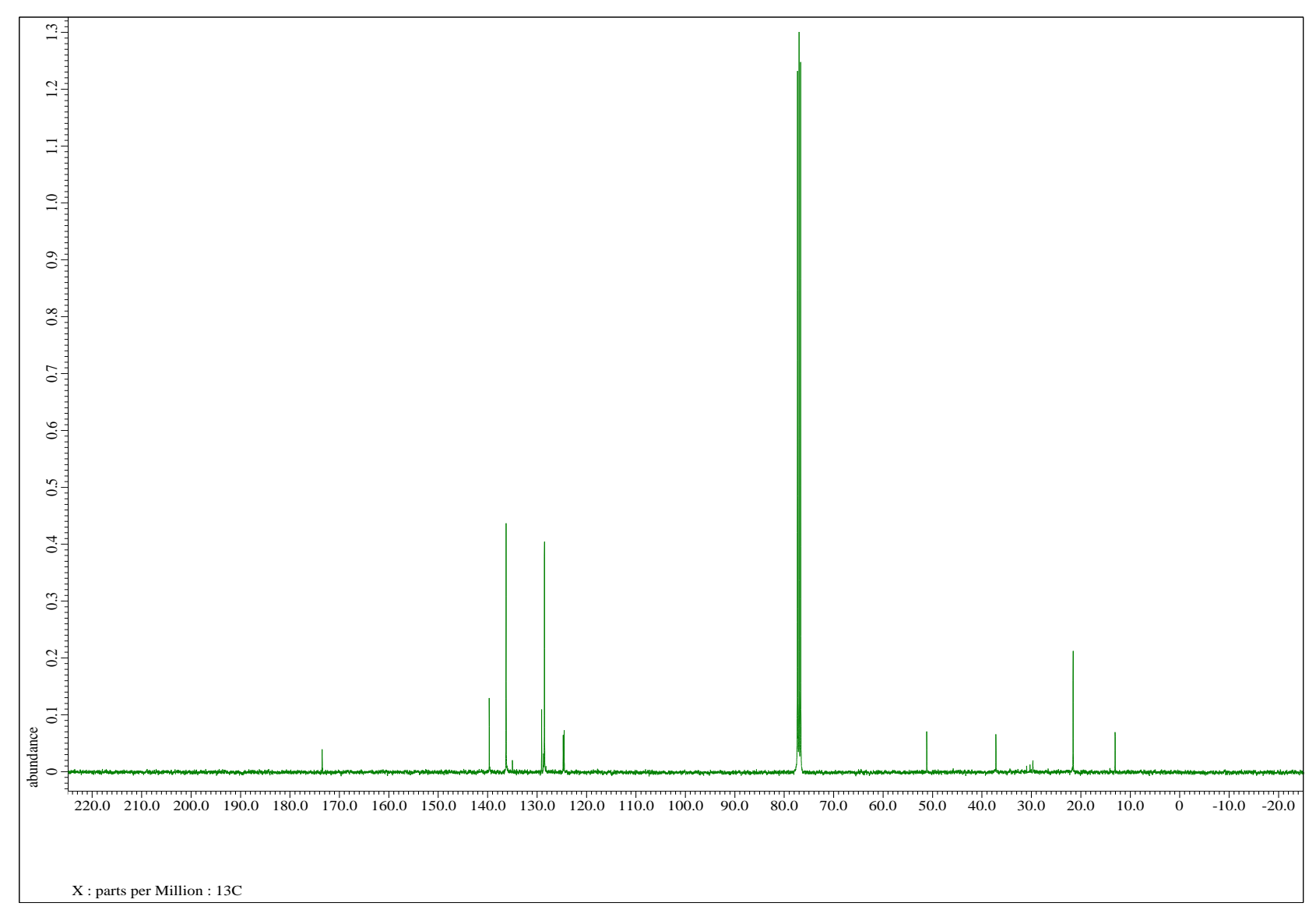

Figure S12. ${ }^{13} \mathrm{C}\left\{{ }^{1} \mathrm{H}\right\}$ NMR spectrum of methyl (Z)-2-(tri-p-tolylsilyl)pent-3-enoate (5ca) in $\mathrm{CDCl}_{3}$ 


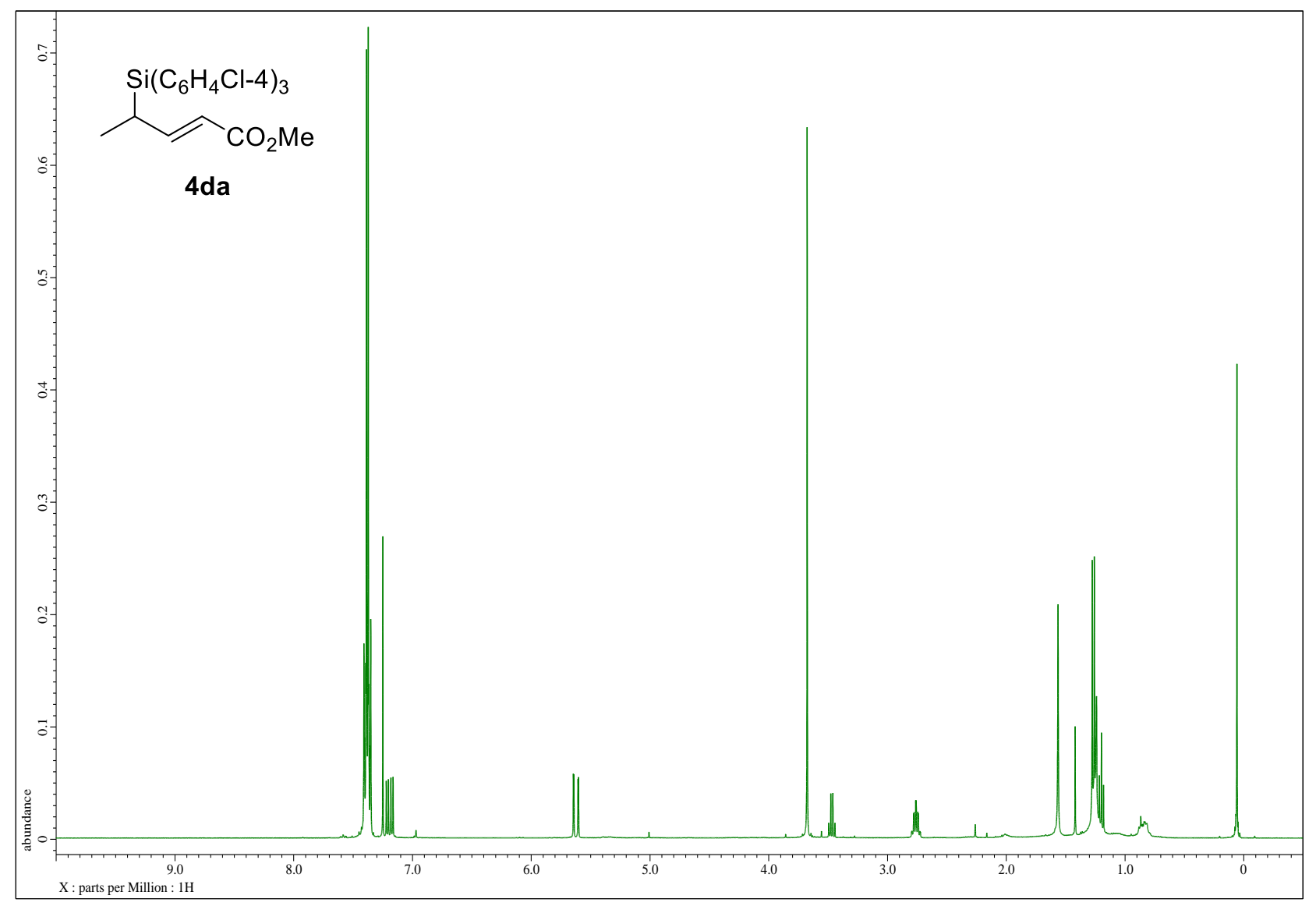

Figure S13. ${ }^{1} \mathrm{H}$ NMR spectrum of methyl (E)-4-(tris(4-chlorophenyl)silyl)pent-2-enoate (4da) in $\mathrm{CDCl}_{3}$

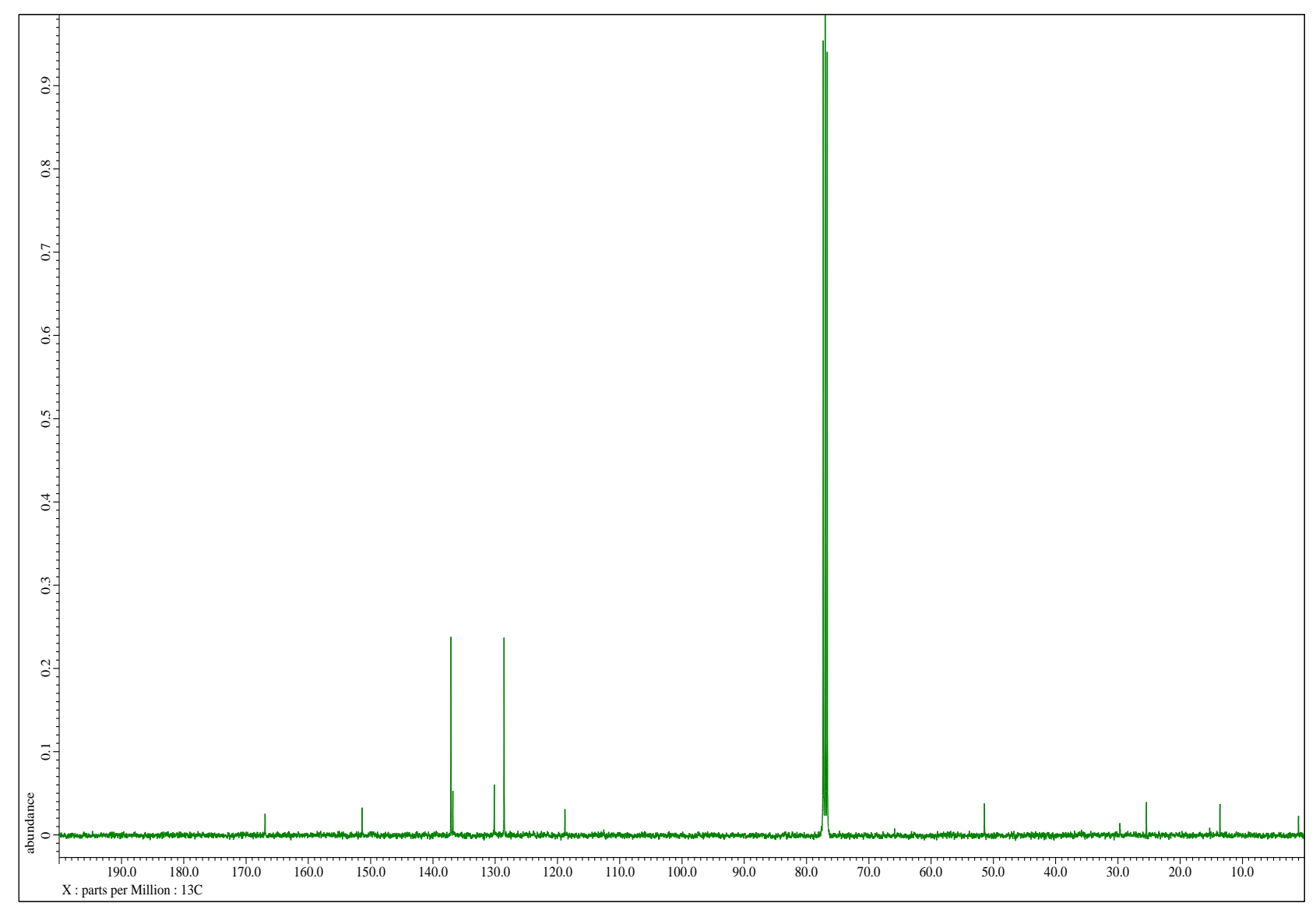

Figure S14. ${ }^{13} \mathrm{C}\left\{{ }^{1} \mathrm{H}\right\}$ NMR spectrum of methyl (E)-4-(tris(4-chlorophenyl)silyl)pent-2-enoate (4da) in $\mathrm{CDCl}_{3}$ 


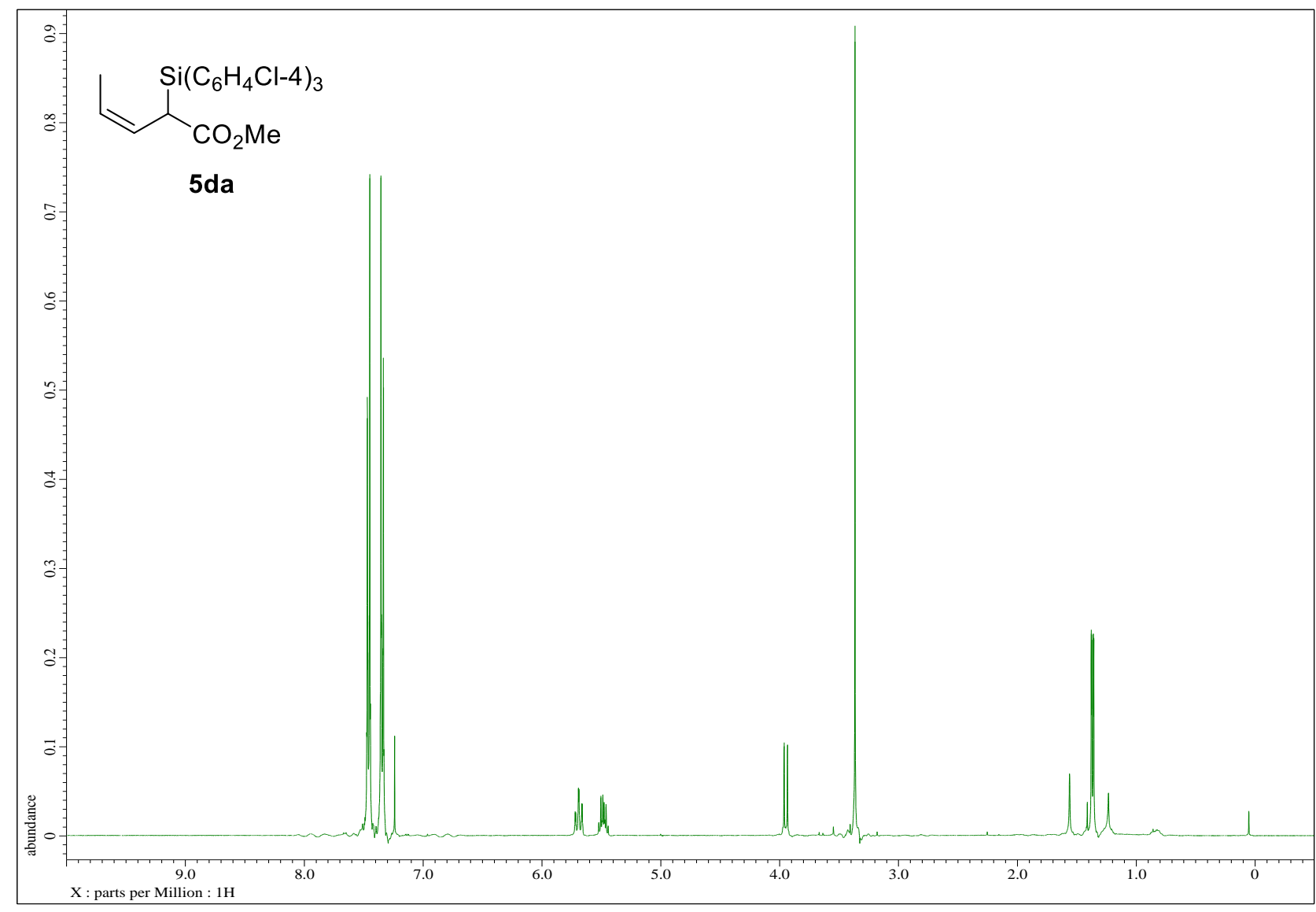

Figure S15. ${ }^{1} \mathrm{H}$ NMR spectrum of methyl (Z)-2-(tris(4-chlorophenyl)silyl)pent-3-enoate (5da) in $\mathrm{CDCl}_{3}$

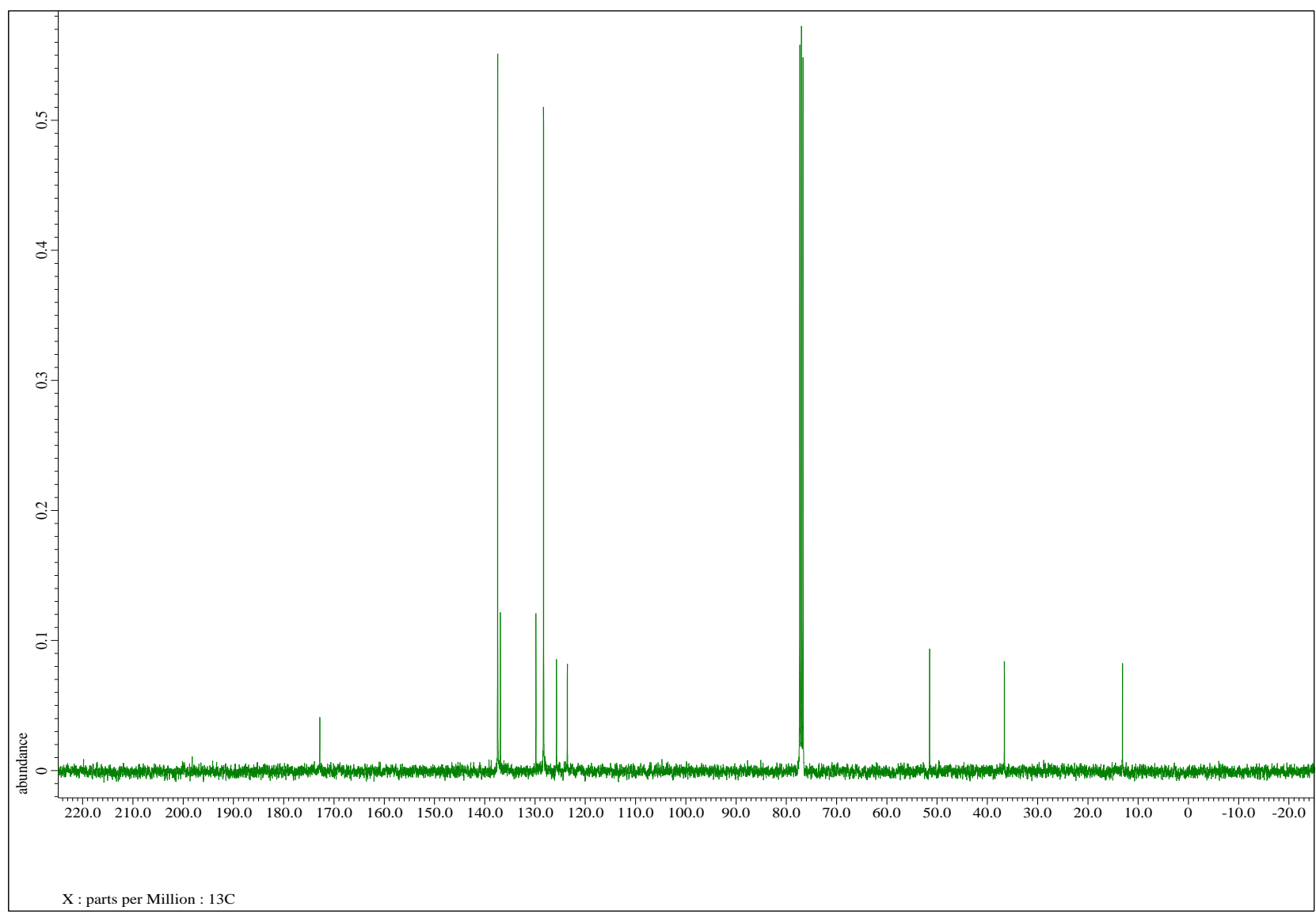

Figure S16. ${ }^{13} \mathrm{C}\left\{{ }^{1} \mathrm{H}\right\}$ NMR spectrum of methyl (Z)-2-(tris(4-chlorophenyl)silyl)pent-3-enoate (5da) in $\mathrm{CDCl}_{3}$ 


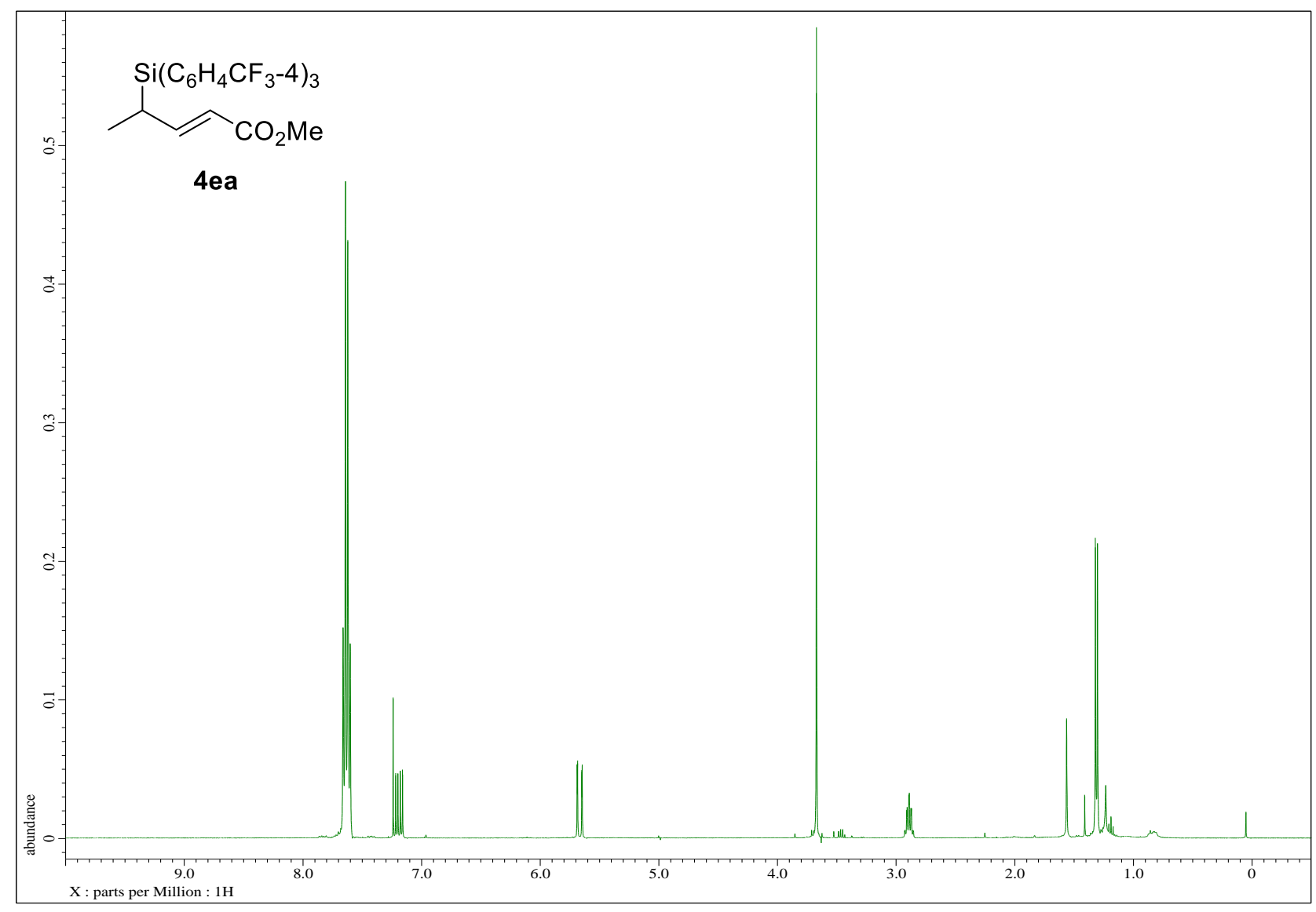

Figure S17. ${ }^{1} \mathrm{H}$ NMR spectrum of methyl (E)-4-(tris(4-(trifluoromethyl)phenyl)silyl)pent-2-enoate (4ea) in $\mathrm{CDCl}_{3}$

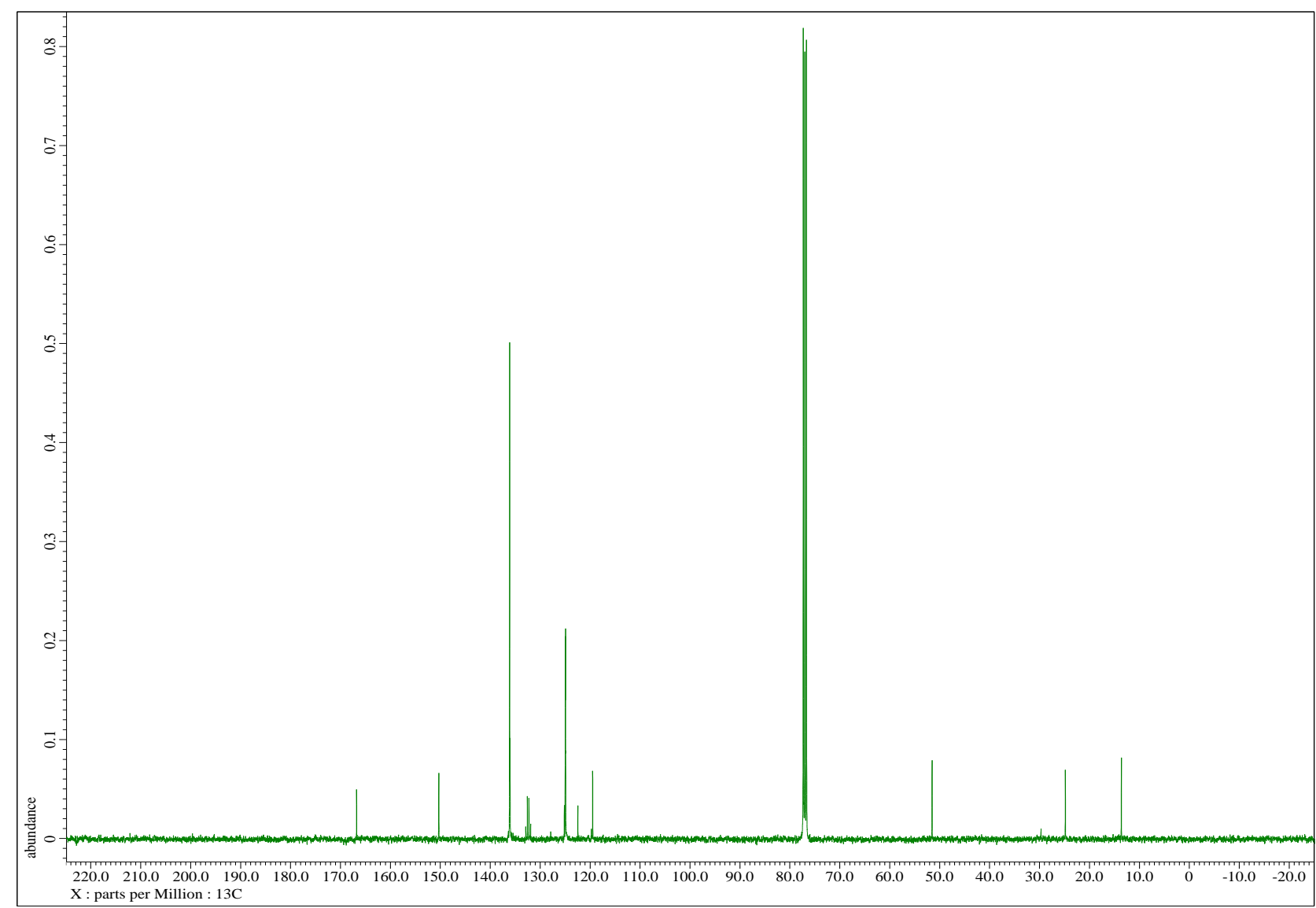

Figure S18. ${ }^{13} \mathrm{C}\left\{{ }^{1} \mathrm{H}\right\}$ NMR spectrum of methyl $(E)$-4-(tris(4-(trifluoromethyl)phenyl)silyl)pent-2-enoate (4ea) in $\mathrm{CDCl}_{3}$ 


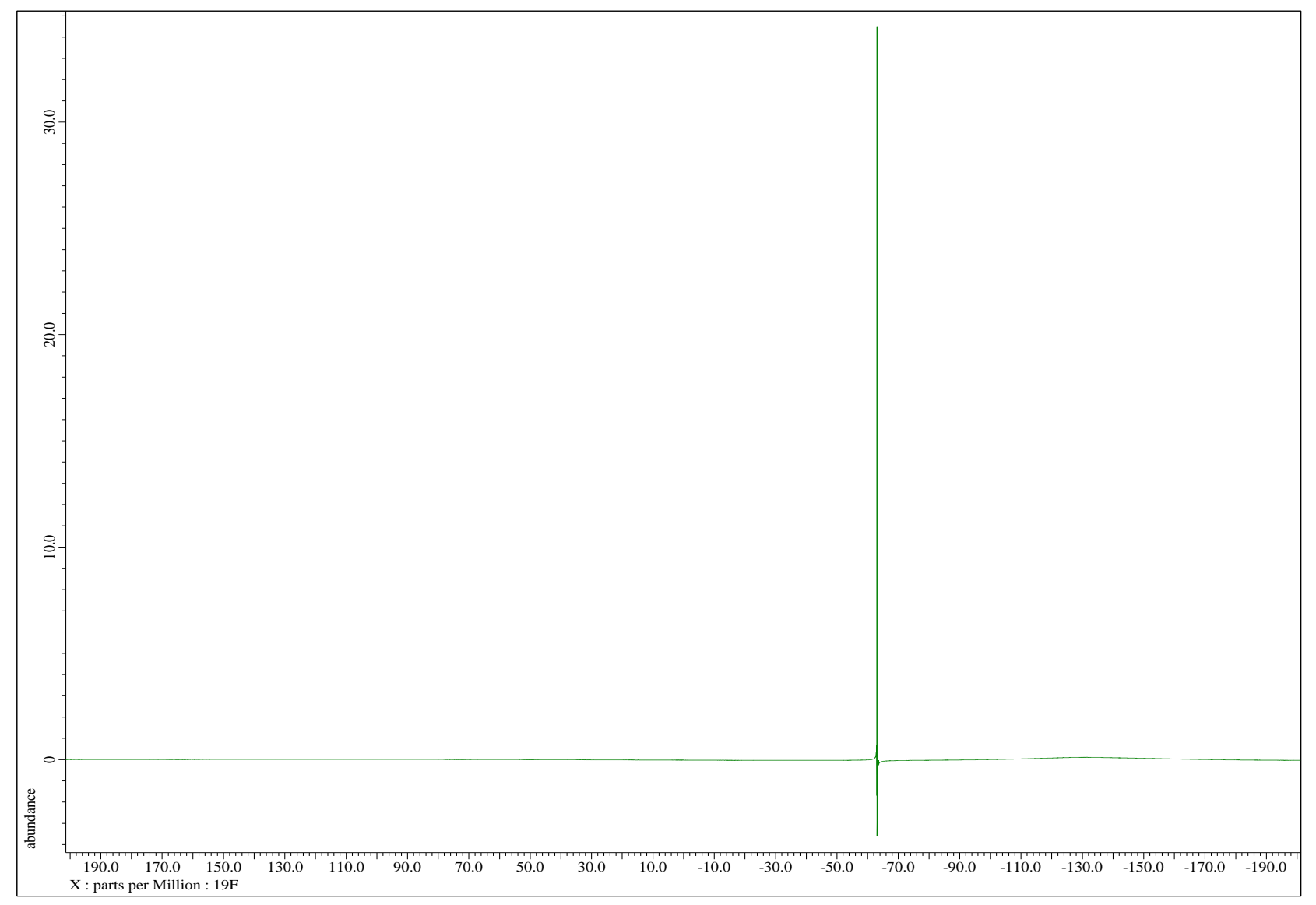

Figure S19. ${ }^{19} \mathrm{~F}\left\{{ }^{1} \mathrm{H}\right\}$ NMR spectrum of methyl $(E)$-4-(tris(4-(trifluoromethyl)phenyl)silyl)pent-2-enoate (4ea) in $\mathrm{CDCl}_{3}$

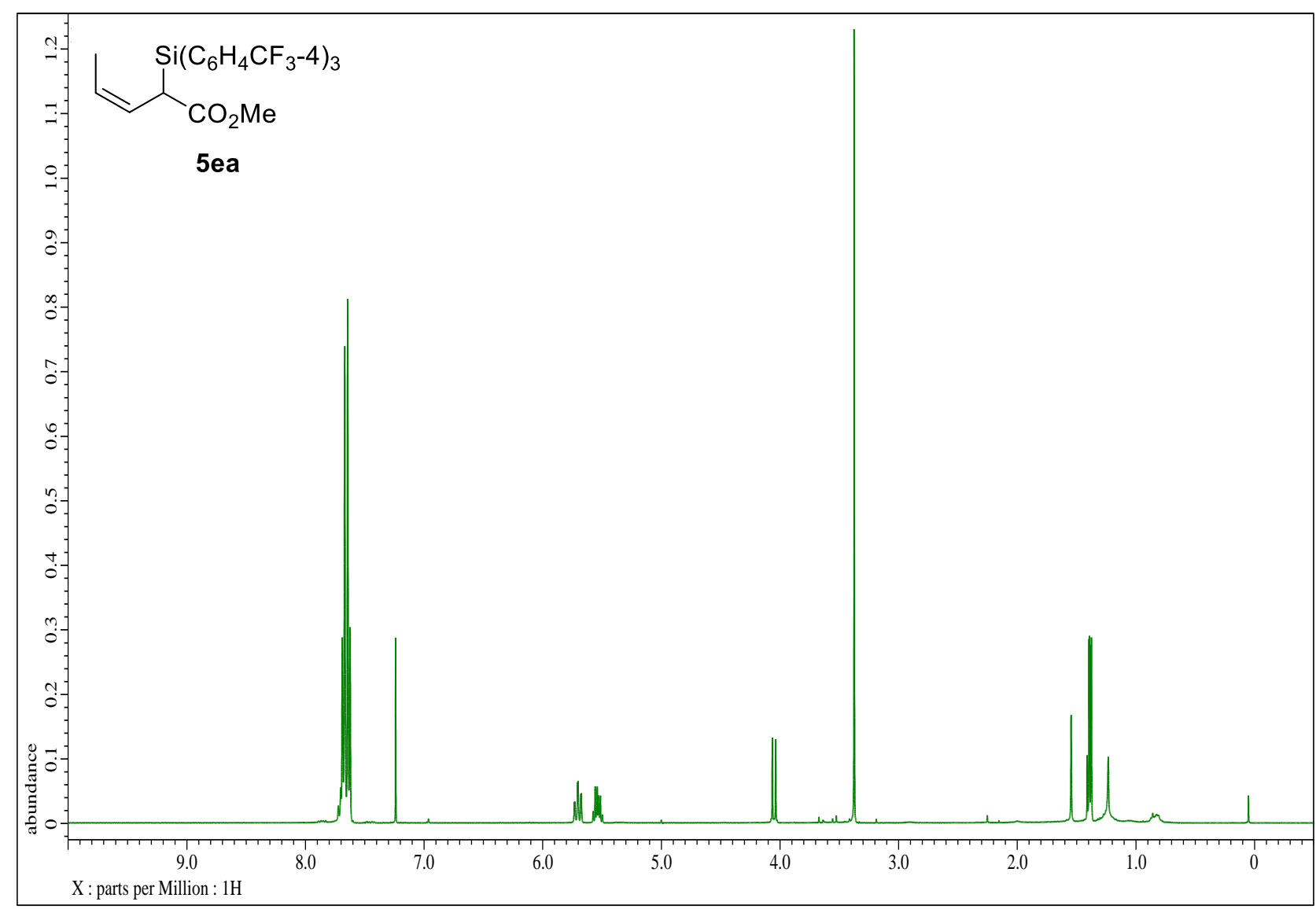

Figure S20. ${ }^{1} \mathrm{H}$ NMR spectrum of methyl (Z)-2-(tris(4-(trifluoromethyl)phenyl)silyl)pent-3-enoate (5ea) in $\mathrm{CDCl}_{3}$ 


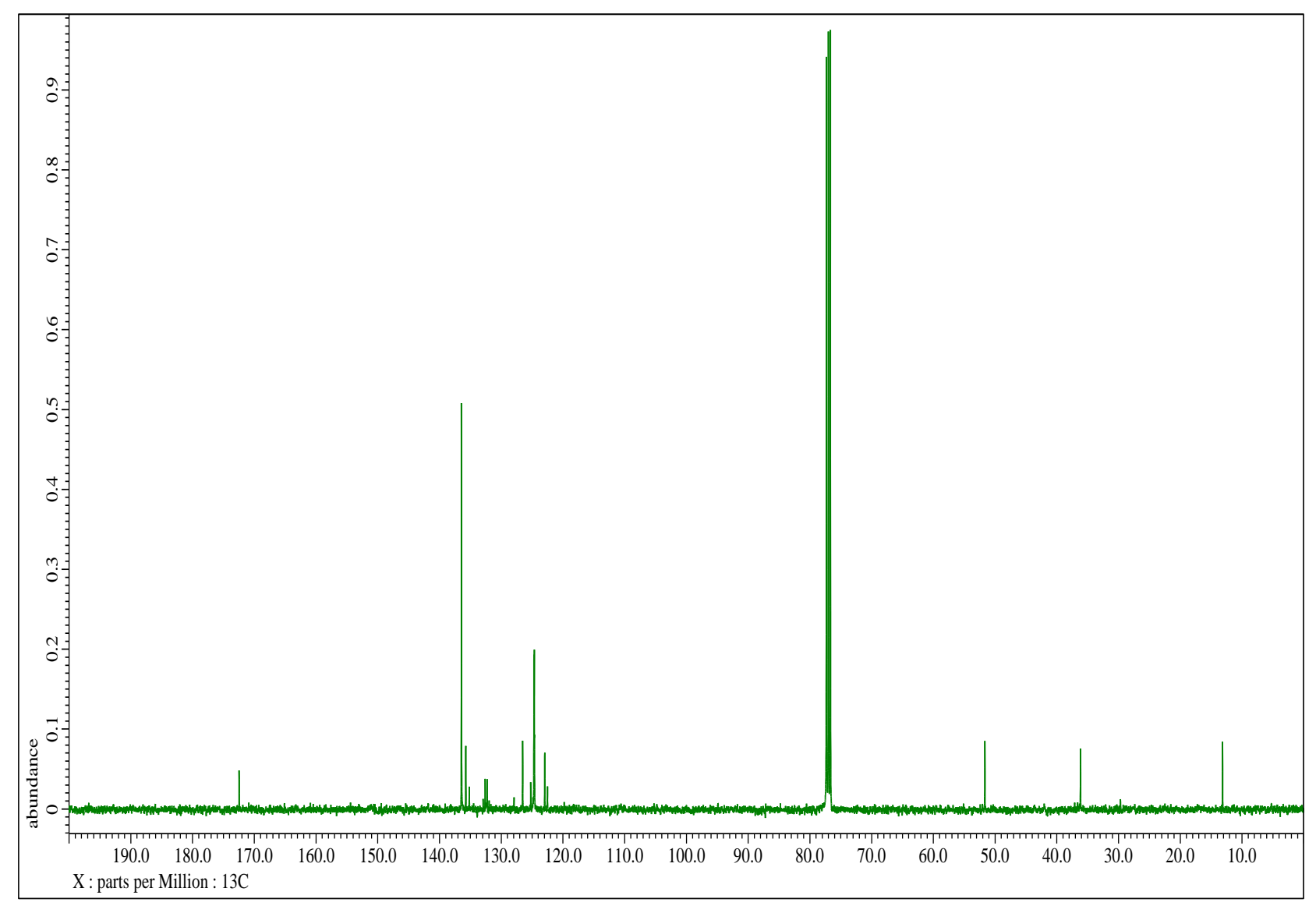

Figure S21. ${ }^{1} \mathrm{H}$ NMR spectrum of methyl (Z)-2-(tris(4-(trifluoromethyl)phenyl)silyl)pent-3-enoate (5ea) in $\mathrm{CDCl}_{3}$

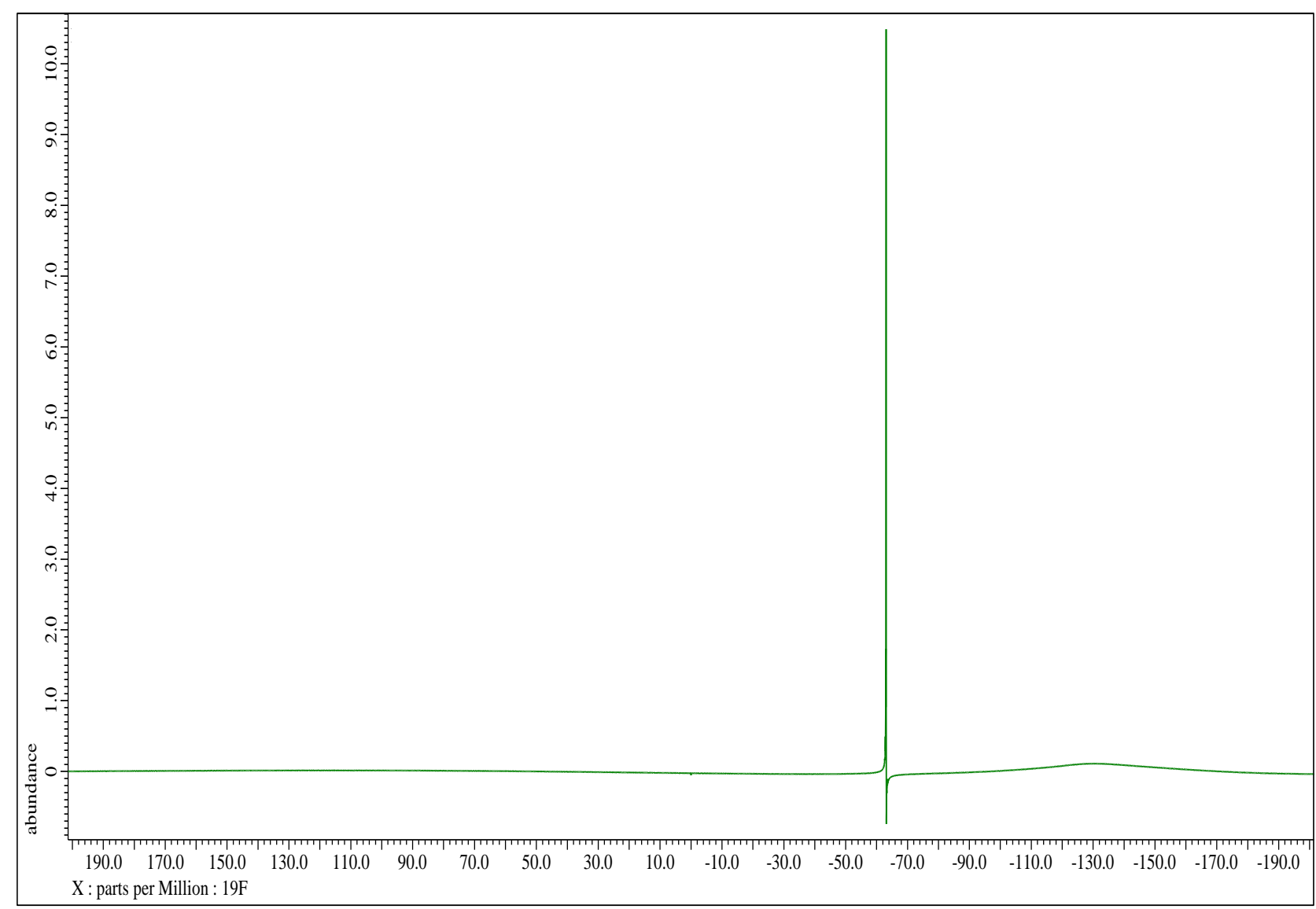

Figure S22. ${ }^{13} \mathrm{C}\left\{{ }^{1} \mathrm{H}\right\}$ NMR spectrum of methyl (Z)-2-(tris(4-(trifluoromethyl)phenyl)silyl)pent-3-enoate (5ea) in $\mathrm{CDCl}_{3}$ 


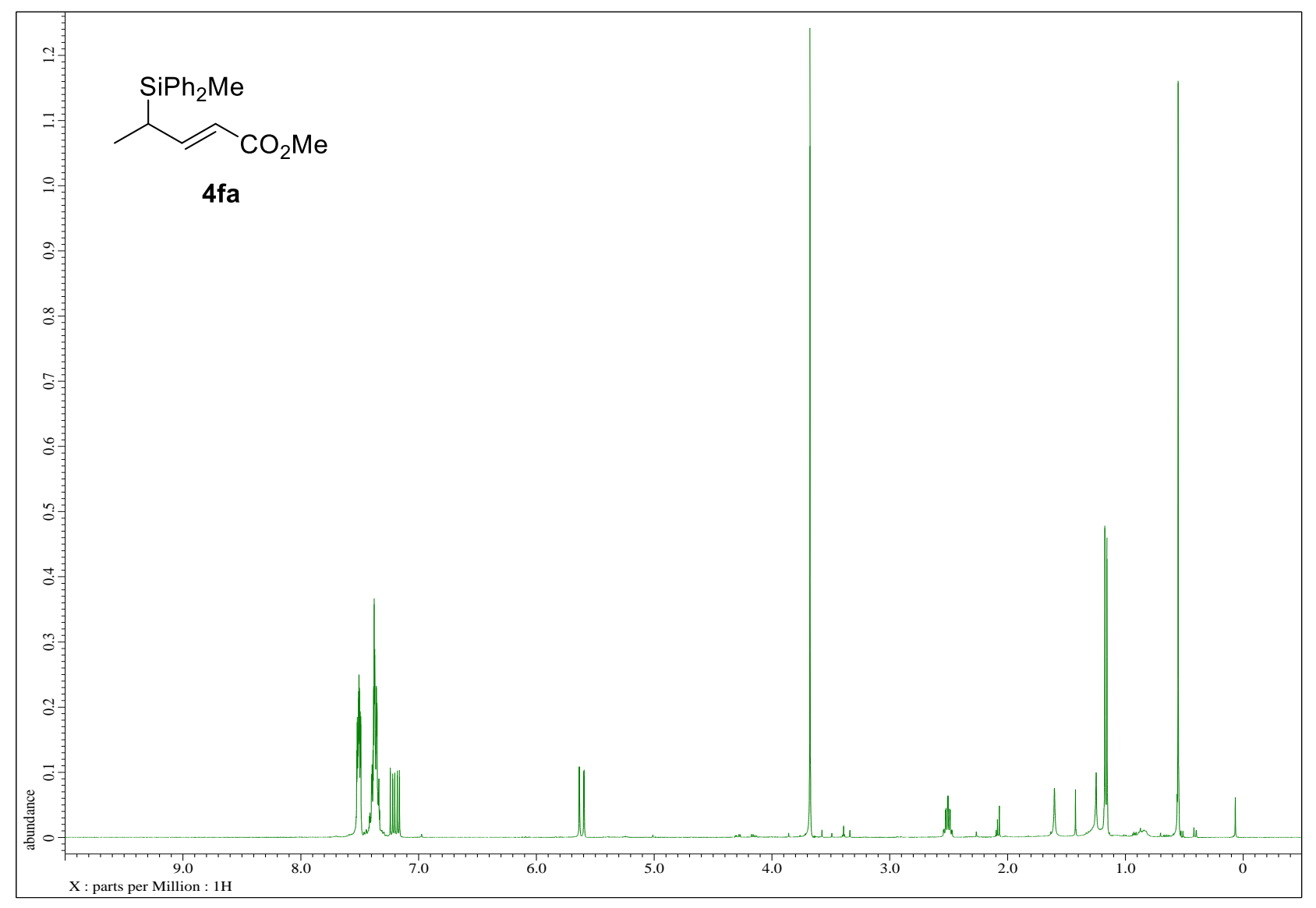

Figure S23. ${ }^{1} \mathrm{H}$ NMR spectra of methyl (E)-4-(methyldiphenylsilyl)pent-2-enoate (4fa) in $\mathrm{CDCl}_{3}$

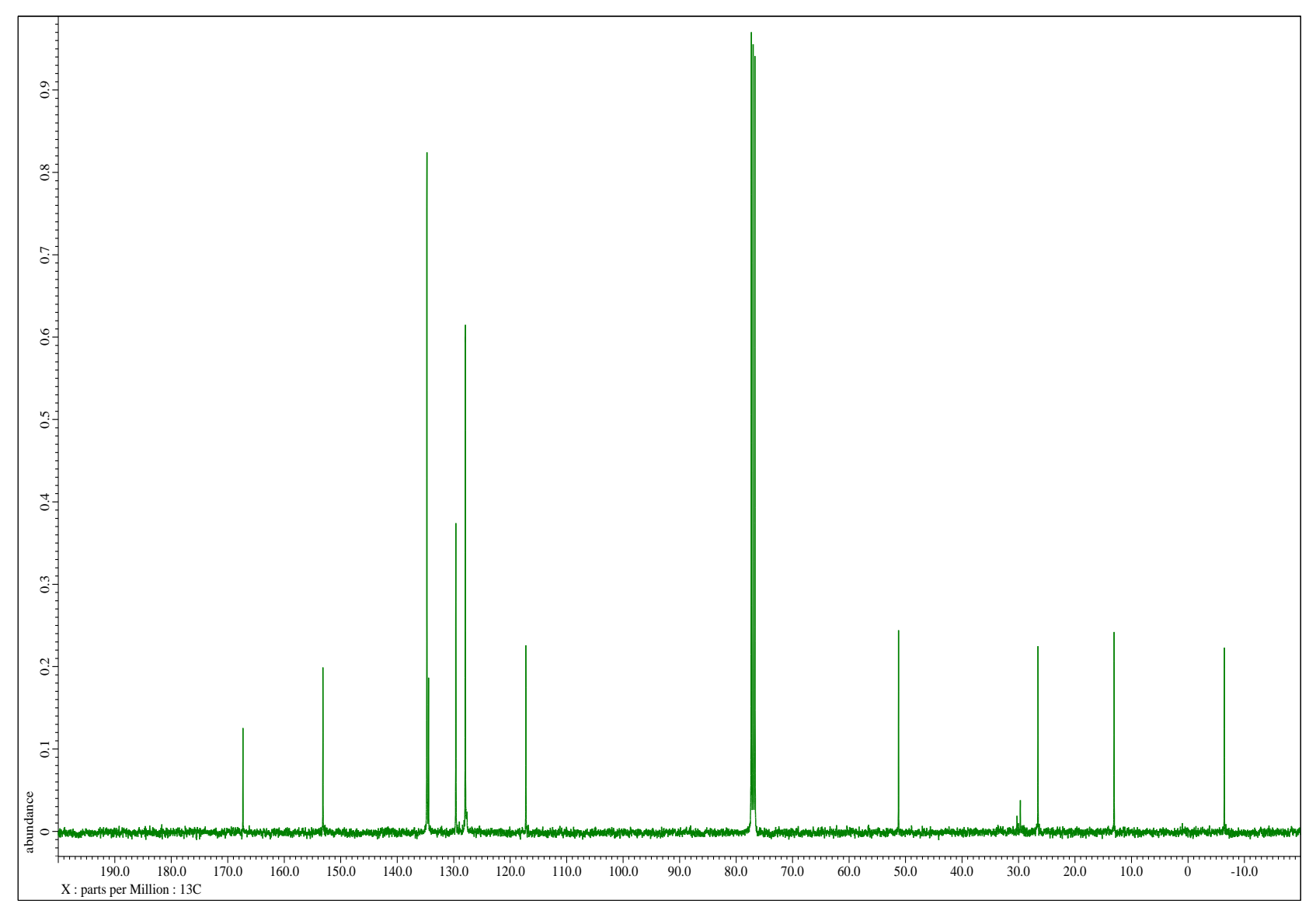

Figure S24. ${ }^{13} \mathrm{C}\left\{{ }^{1} \mathrm{H}\right\}$ NMR spectra of methyl $(E)$-4-(methyldiphenylsilyl)pent-2-enoate (4fa) in $\mathrm{CDCl}_{3}$ 


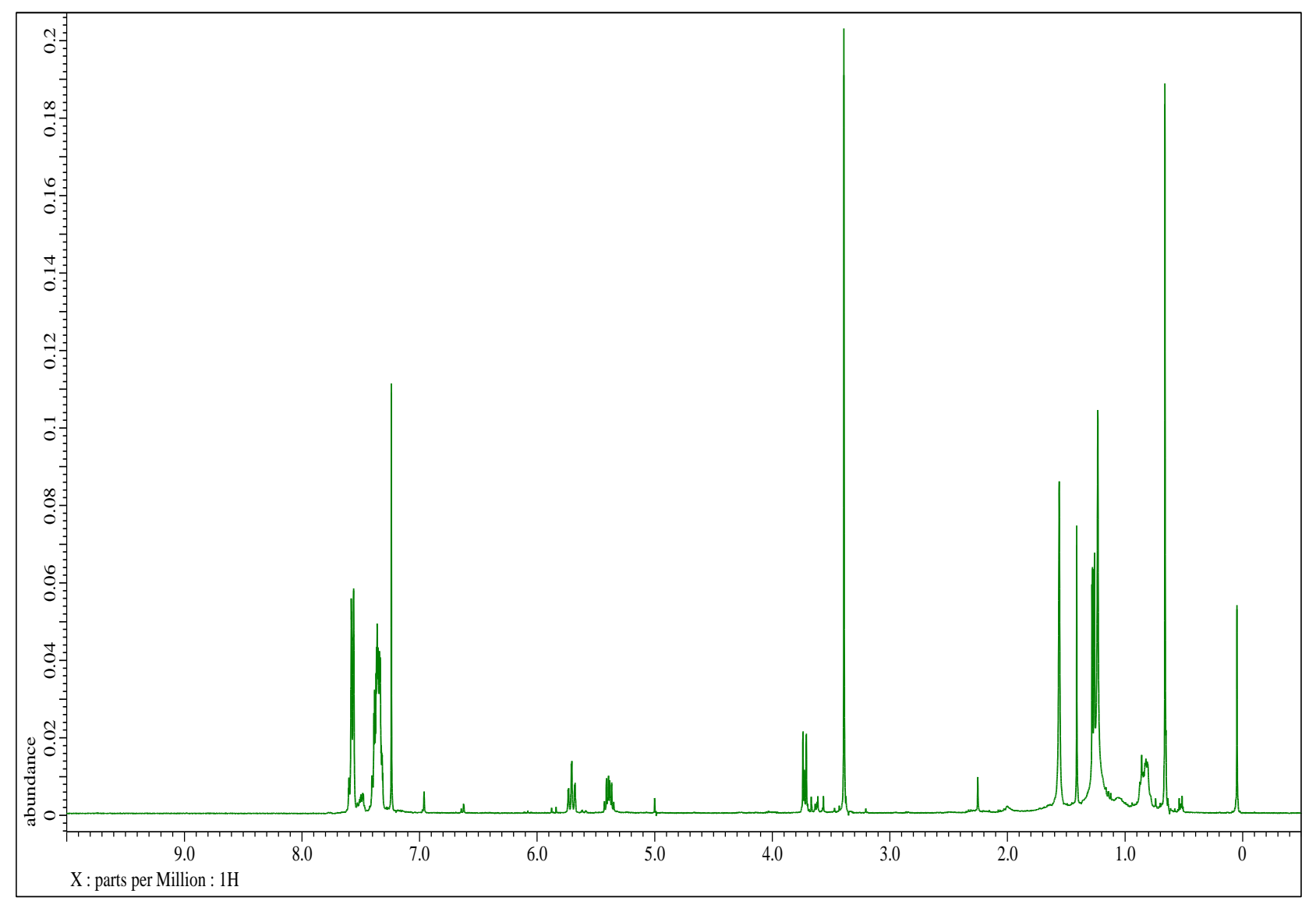

Figure S25. ${ }^{1} \mathrm{H}$ NMR spectra of methyl (Z)-2-(methyldiphenylsilyl)pent-3-enoate (5fa) in $\mathrm{CDCl}_{3}$

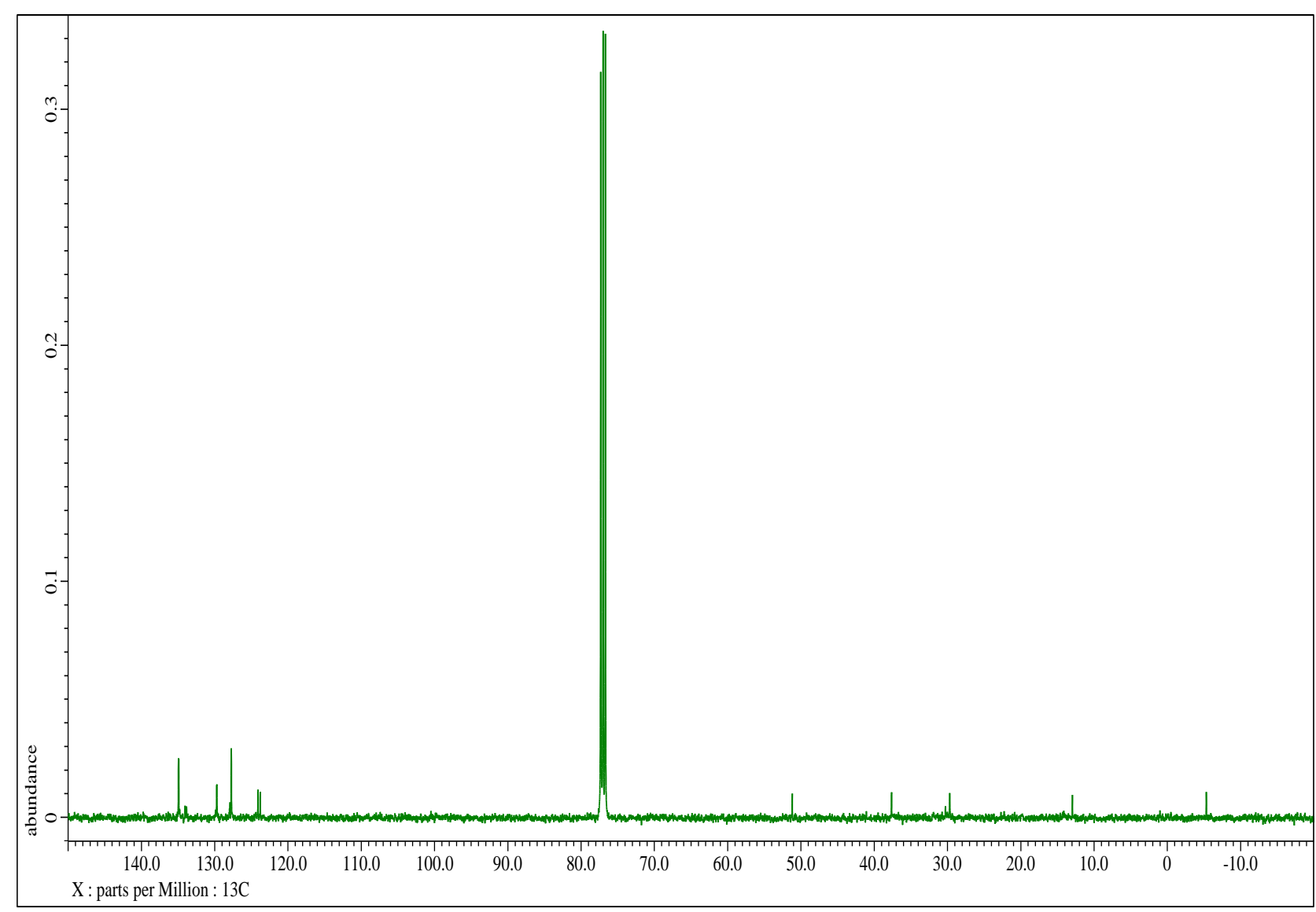

Figure S26. ${ }^{13} \mathrm{C}\left\{{ }^{1} \mathrm{H}\right\}$ NMR spectra of methyl (Z)-2-(methyldiphenylsilyl)pent-3-enoate (5fa) in $\mathrm{CDCl}_{3}$ 


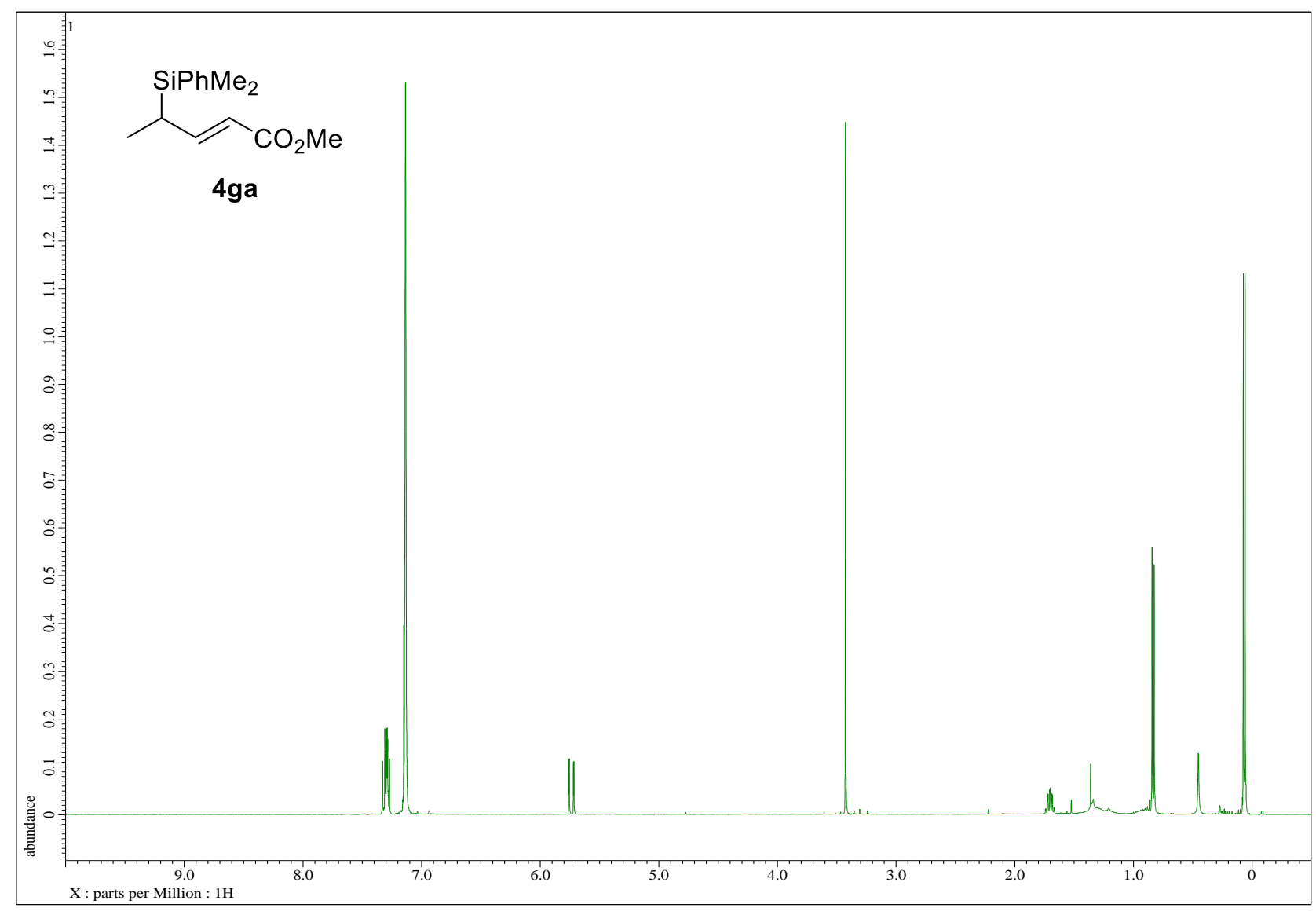

Figure S27. ${ }^{1} \mathrm{H}$ NMR spectrum of methyl (E)-4-(dimethyl(phenyl)silyl)pent-2-enoate (4ga) in $\mathrm{C}_{6} \mathrm{D}_{6}$

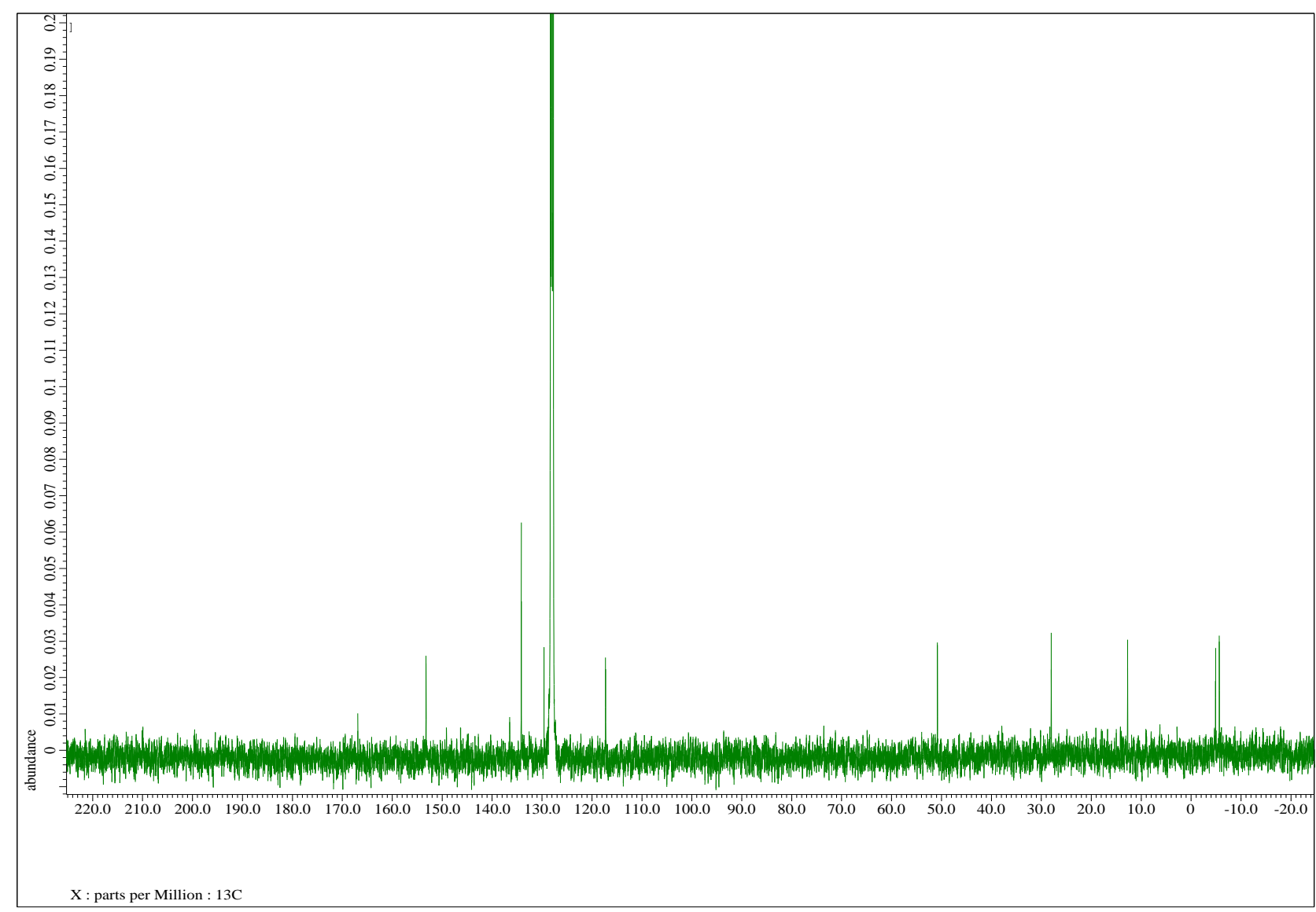

Figure S28. ${ }^{13} \mathrm{C}$ NMR spectrum of methyl (E)-4-(dimethyl(phenyl)silyl)pent-2-enoate (4ga) in $\mathrm{C}_{6} \mathrm{D}_{6}$ 


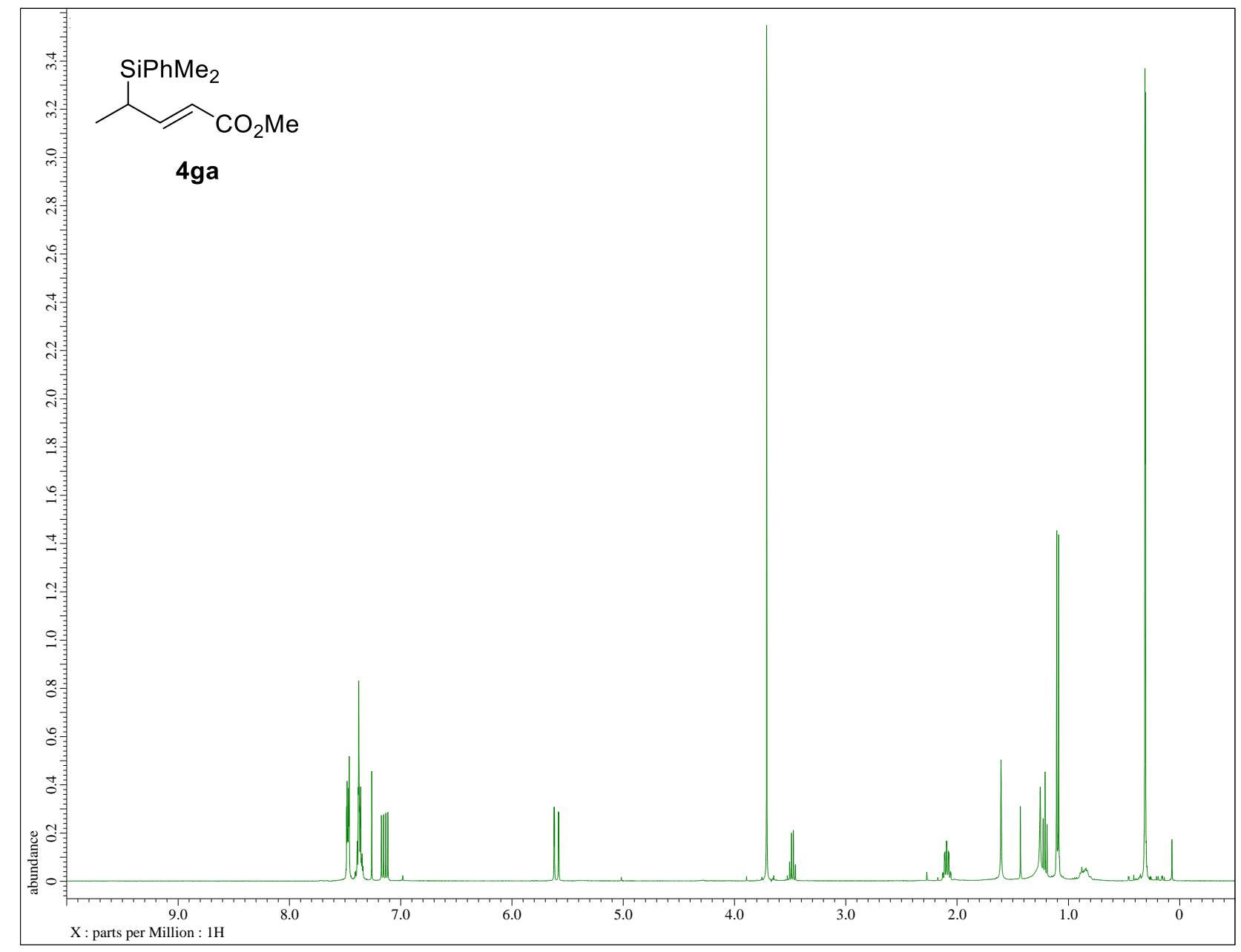

Figure S29. ${ }^{1} \mathrm{H}$ NMR spectrum of methyl (E)-4-(dimethyl(phenyl)silyl)pent-2-enoate (4ga) in $\mathrm{CDCl}_{3}$

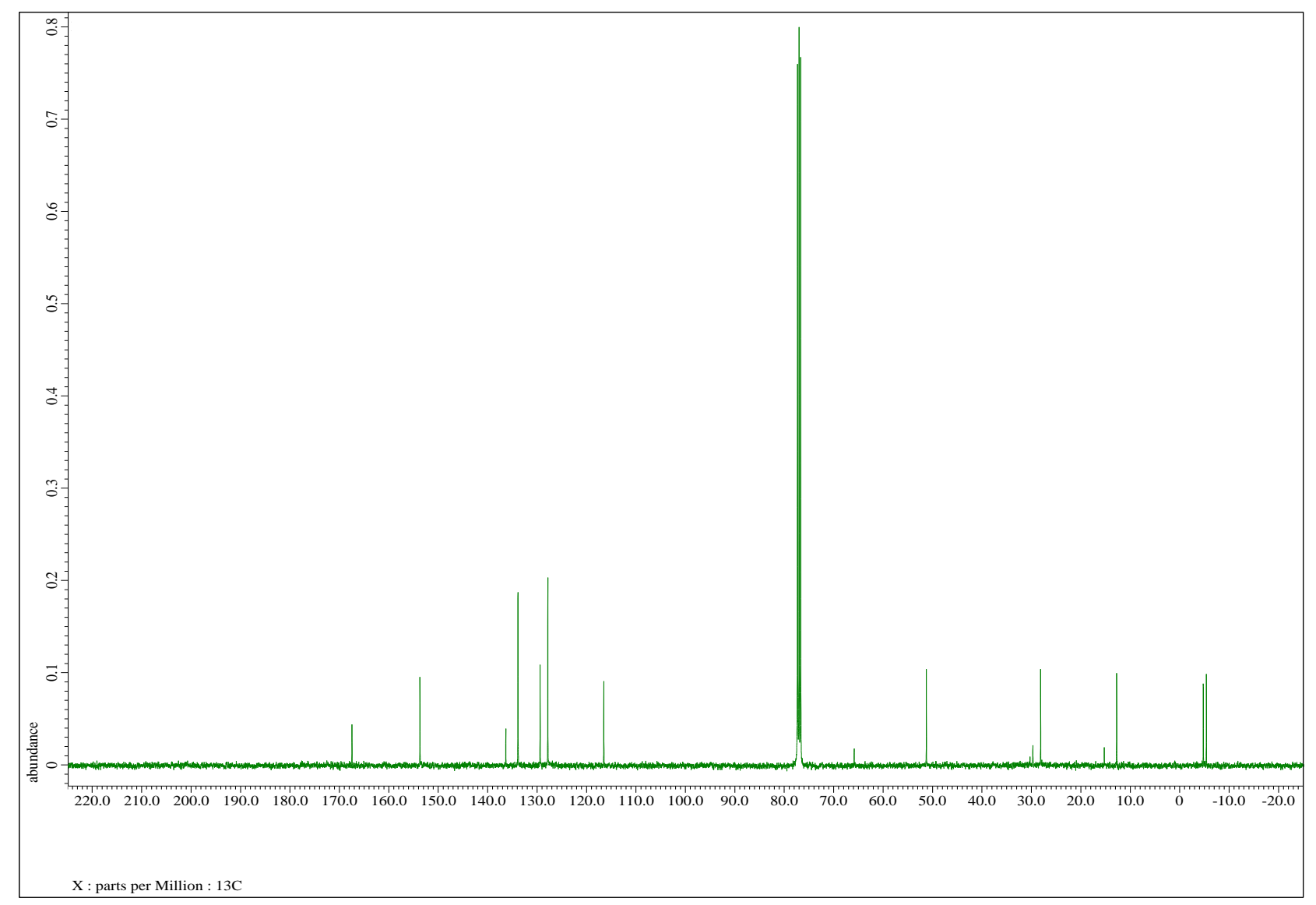

Figure S30. ${ }^{13} \mathrm{C}\left\{{ }^{1} \mathrm{H}\right\}$ NMR spectrum of methyl (E)-4-(dimethyl(phenyl)silyl)pent-2-enoate (4ga) $\left(\mathrm{CDCl}_{3}\right)$. 


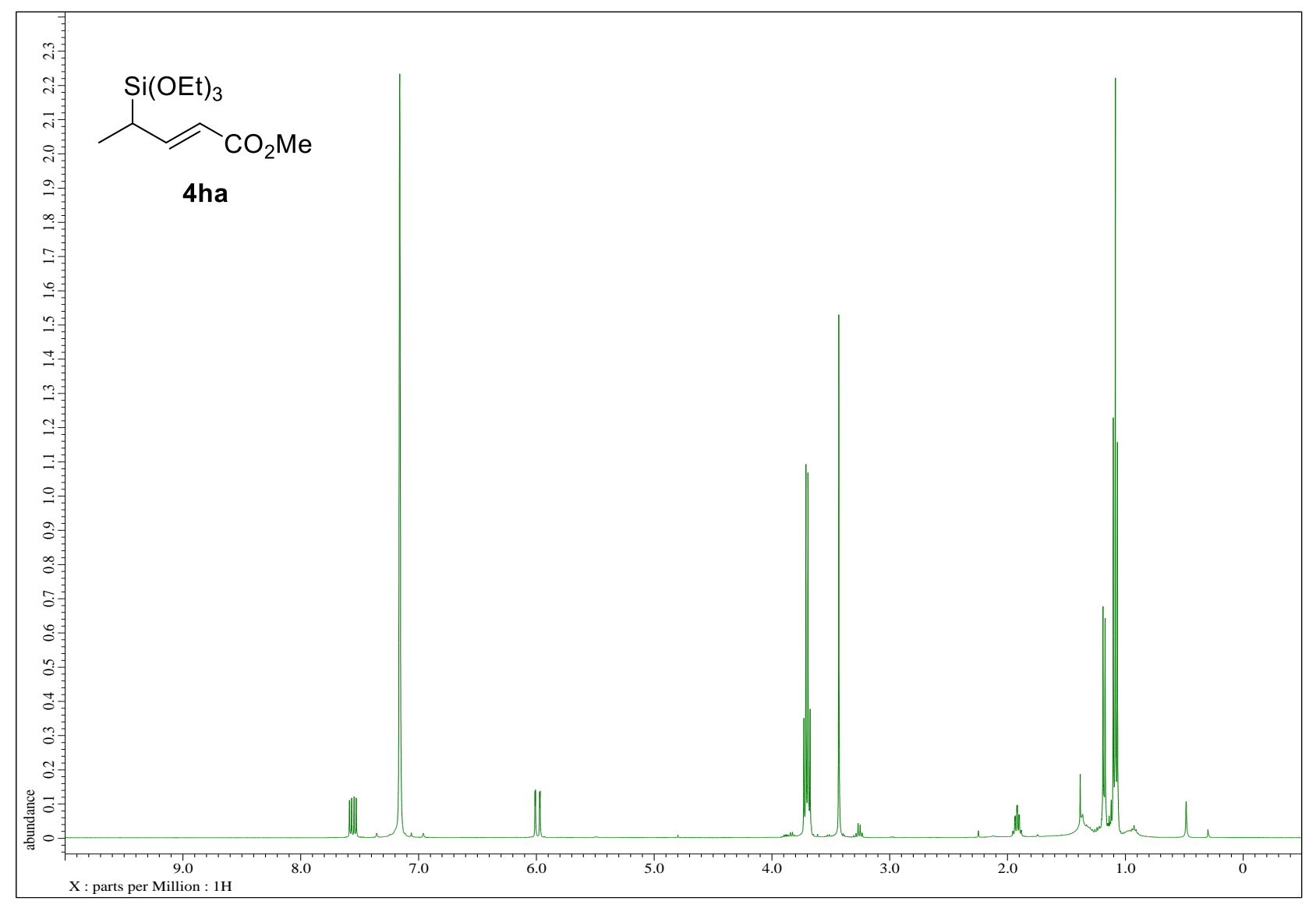

Figure S31. ${ }^{1} \mathrm{H}$ NMR spectra of methyl (E)-4-(triethoxysilyl)pent-2-enoate (4ha) in $\mathrm{C}_{6} \mathrm{D}_{6}$

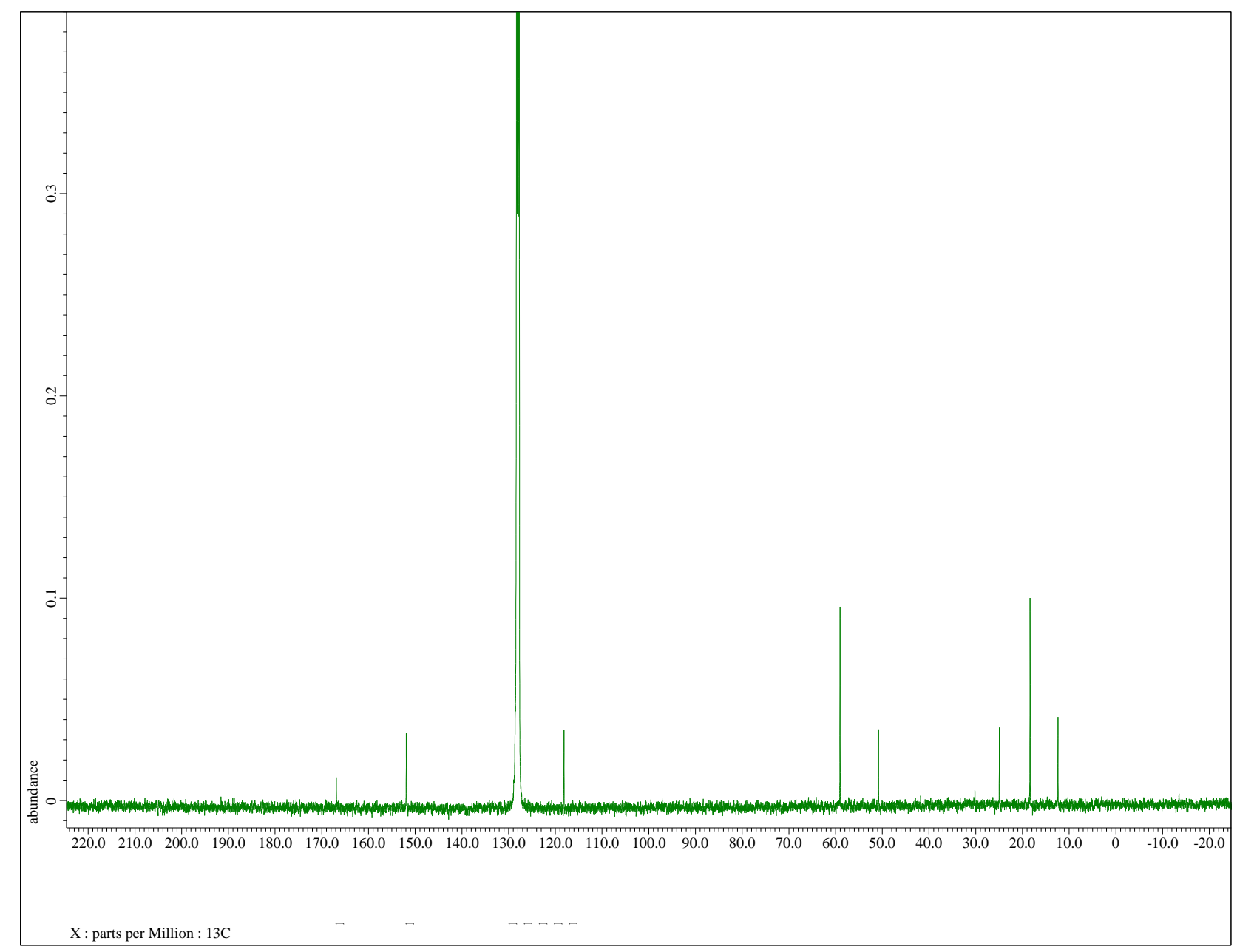

Figure S32. ${ }^{13} \mathrm{C}\left\{{ }^{1} \mathrm{H}\right\}$ NMR spectra of methyl $(E)$-4-(triethoxysilyl)pent-2-enoate (4ha) in $\mathrm{C}_{6} \mathrm{D}_{6}$ 


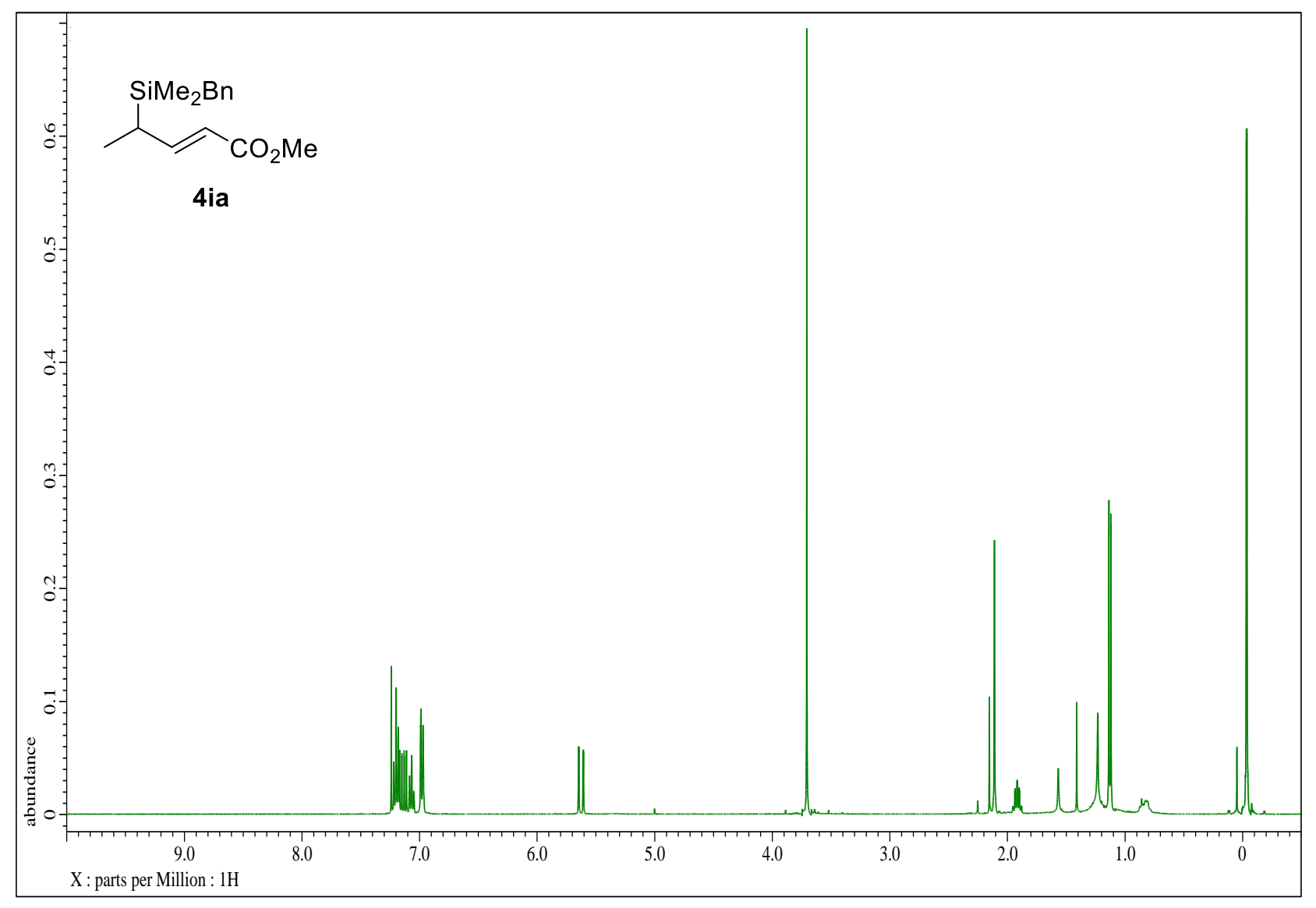

Figure S33. ${ }^{1} \mathrm{H}$ NMR spectra of methyl (E)-4-(benzyldimethylsilyl)pent-2-enoate (4ia) in $\mathrm{CDCl}_{3}$

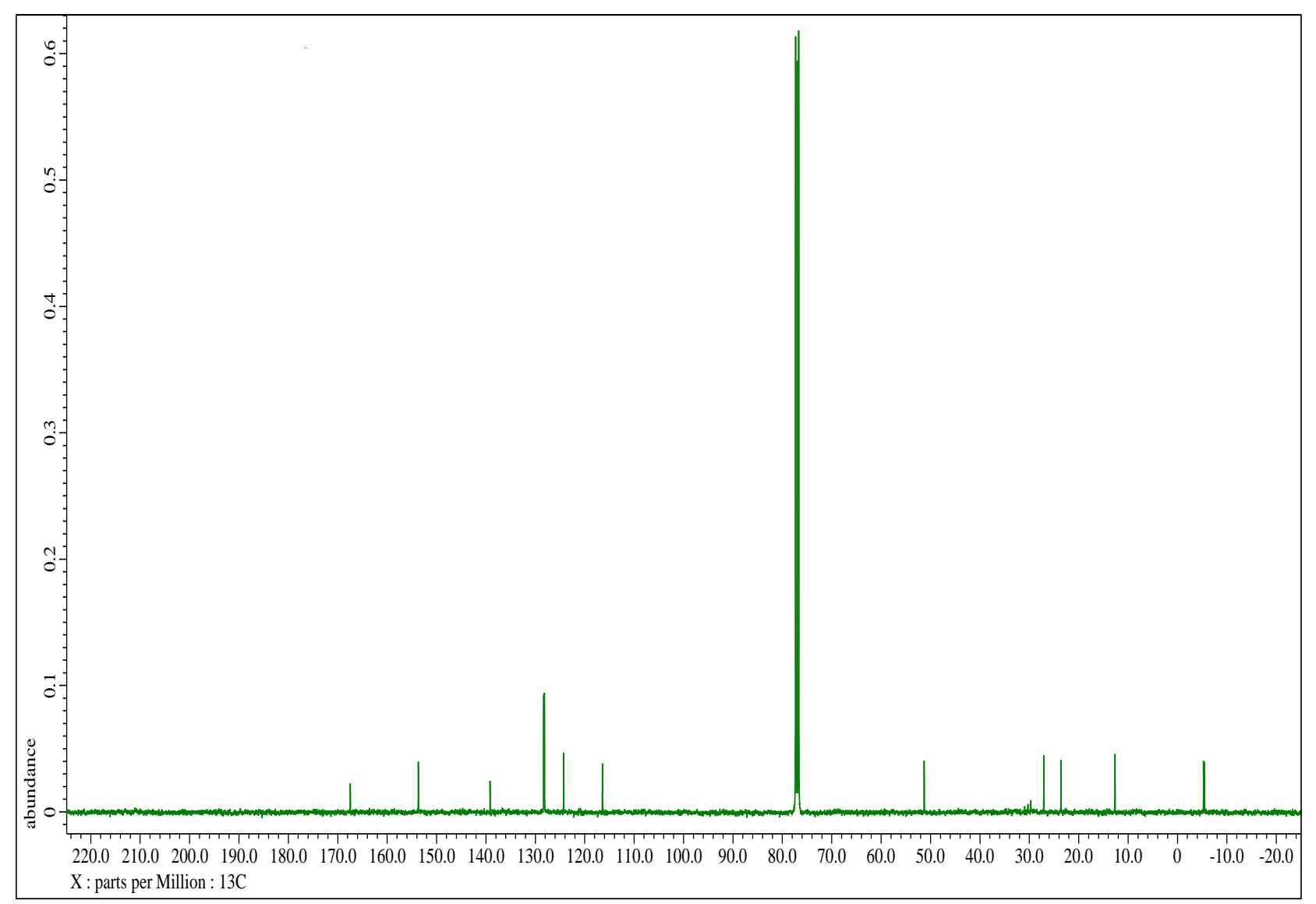

Figure S34. ${ }^{13} \mathrm{C}\left\{{ }^{1} \mathrm{H}\right\}$ NMR spectra of methyl (E)-4-(benzyldimethylsilyl)pent-2-enoate (4ia) in $\mathrm{CDCl}_{3}$ 


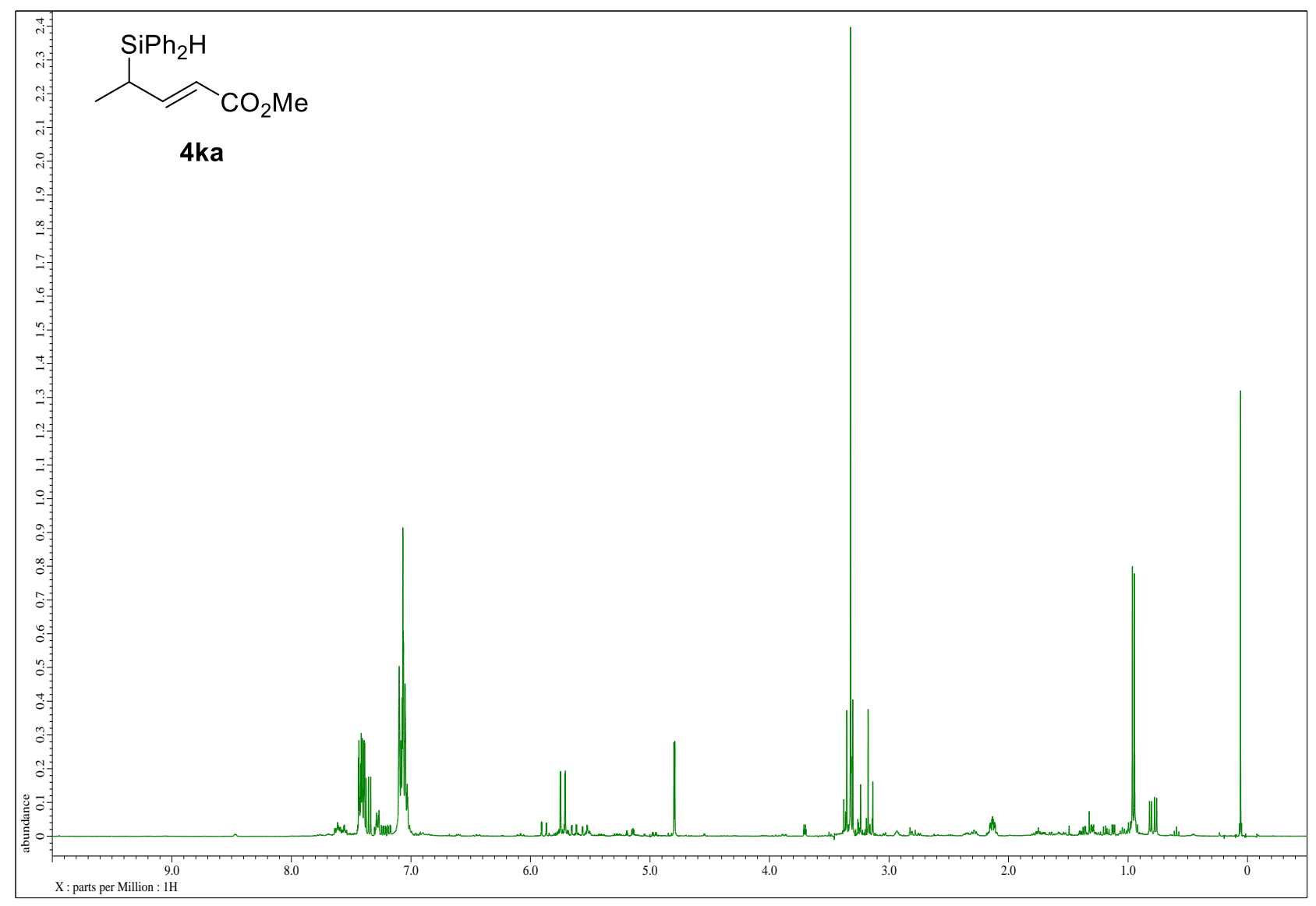

Figure S35. ${ }^{1} \mathrm{H}$ NMR spectra of methyl (E)-4-(diphenylsilyl)pent-2-enoate (4ka) in $\mathrm{C}_{6} \mathrm{D}_{6}$

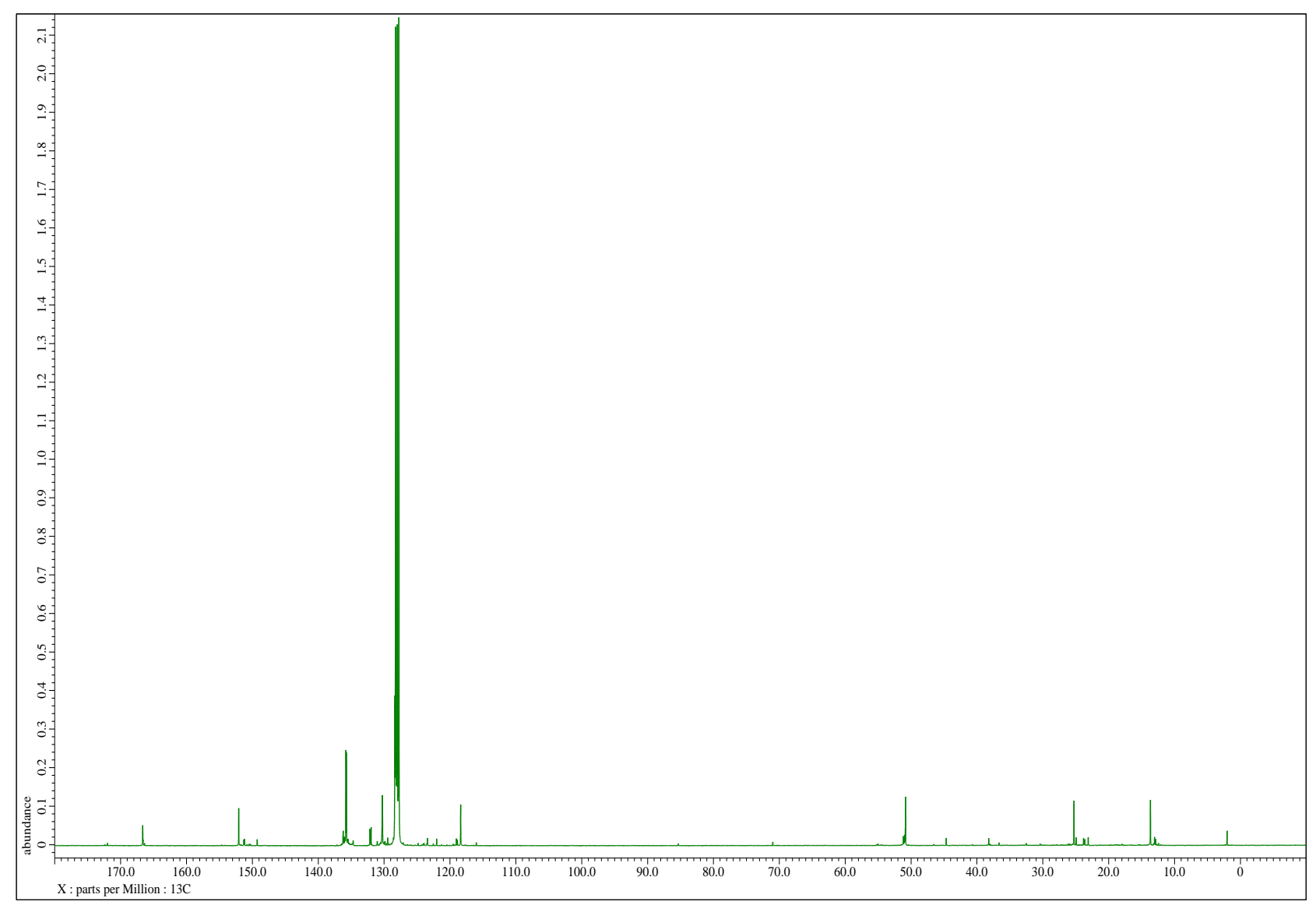

Figure S36. ${ }^{13} \mathrm{C}\left\{{ }^{1} \mathrm{H}\right\}$ NMR spectra of methyl (E)-4-(diphenylsilyl)pent-2-enoate (4ka) in $\mathrm{C}_{6} \mathrm{D}_{6}$ 


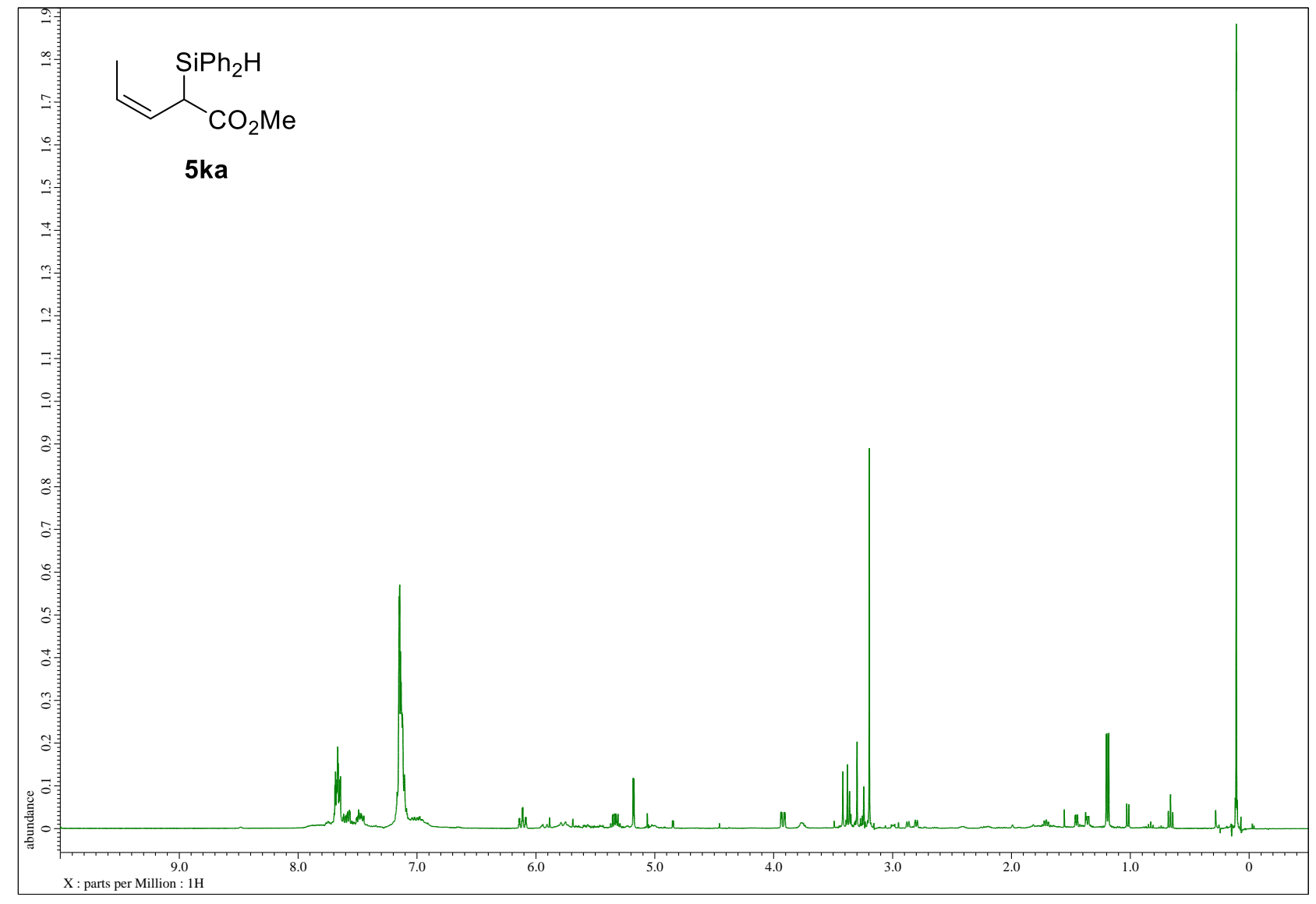

Figure S37. ${ }^{1} \mathrm{H}$ NMR spectra of methyl (Z)-2-(diphenylsilyl)pent-3-enoate (5ka) in $\mathrm{C}_{6} \mathrm{D}_{6}$

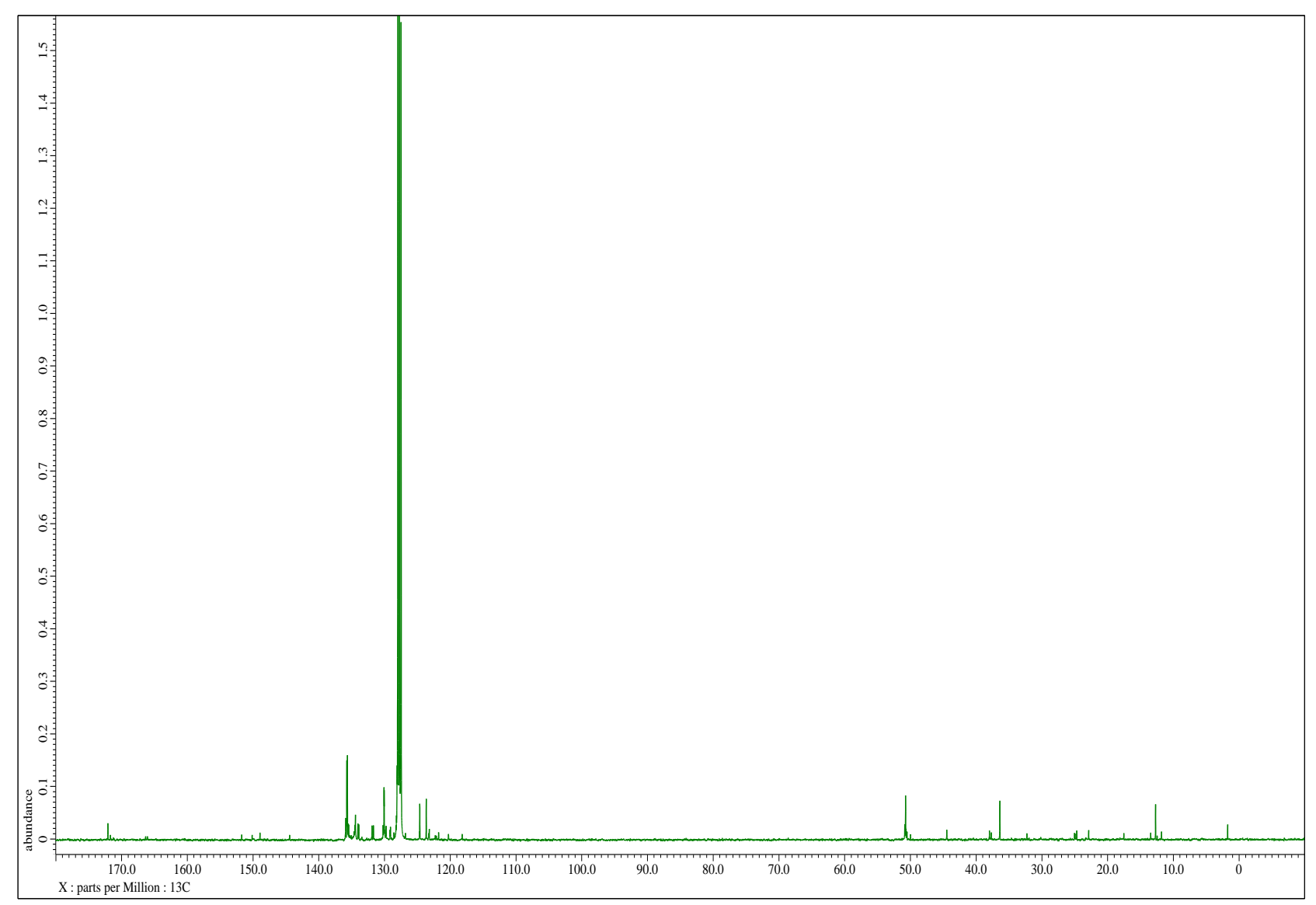

Figure S38. ${ }^{13} \mathrm{C}\left\{{ }^{1} \mathrm{H}\right\}$ NMR of methyl (Z)-2-(diphenylsilyl)pent-3-enoate (5ka) in $\mathrm{C}_{6} \mathrm{D}_{6}$ 


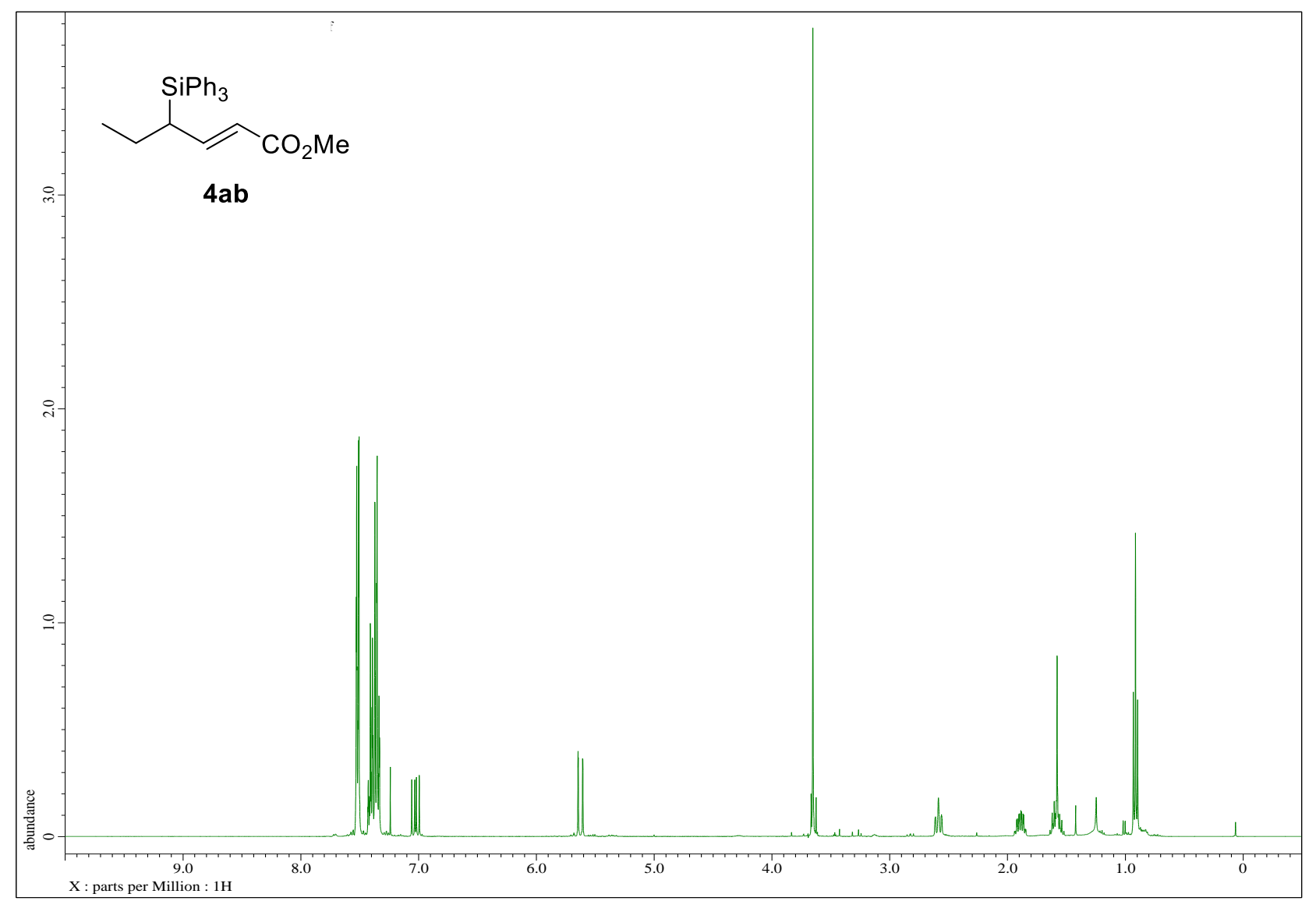

Figure S39. ${ }^{1} \mathrm{H}$ NMR spectra of methyl (E)-4-(triphenylsilyl)hex-2-enoate (4ab) in $\mathrm{CDCl}_{3}$

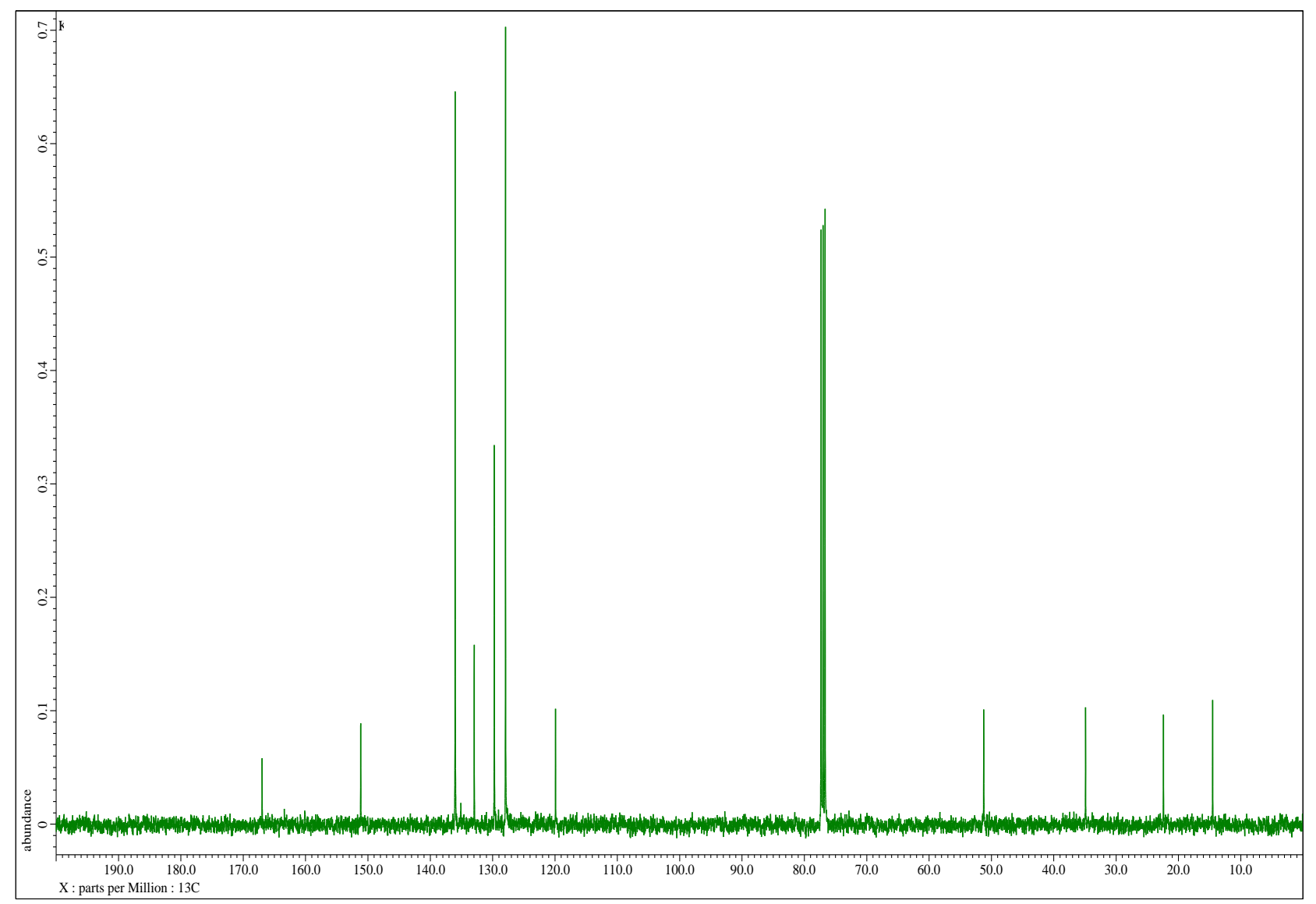

Figure S40. ${ }^{13} \mathrm{C}\left\{{ }^{1} \mathrm{H}\right\}$ NMR spectra of methyl $(E)$-4-(triphenylsilyl)hex-2-enoate (4ab) in $\mathrm{CDCl}_{3}$ 


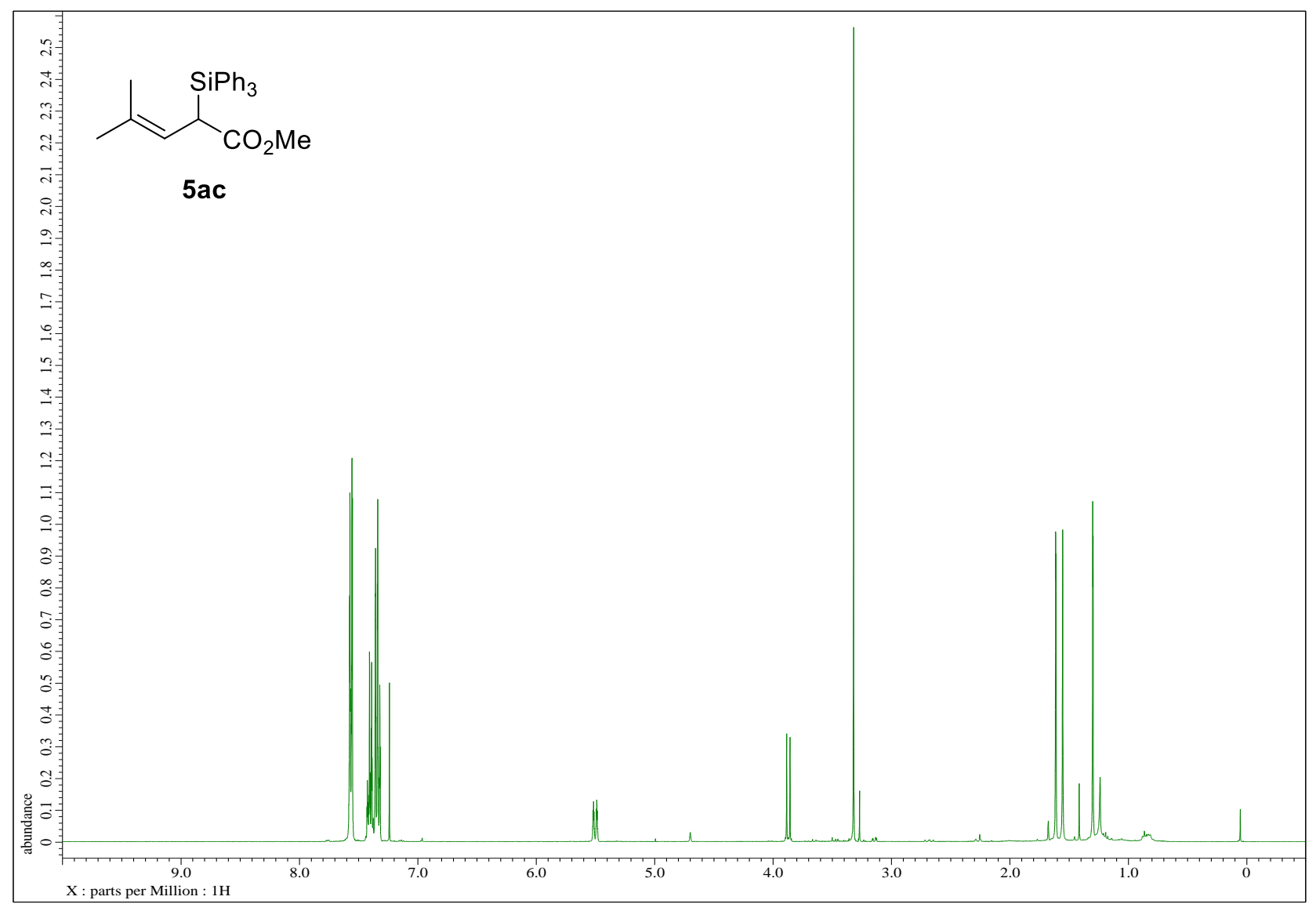

Figure S41. ${ }^{1} \mathrm{H}$ NMR spectra of spectra of methyl 4-methyl-2-(triphenylsilyl)pent-3-enoate (5ac) in $\mathrm{CDCl}_{3}$

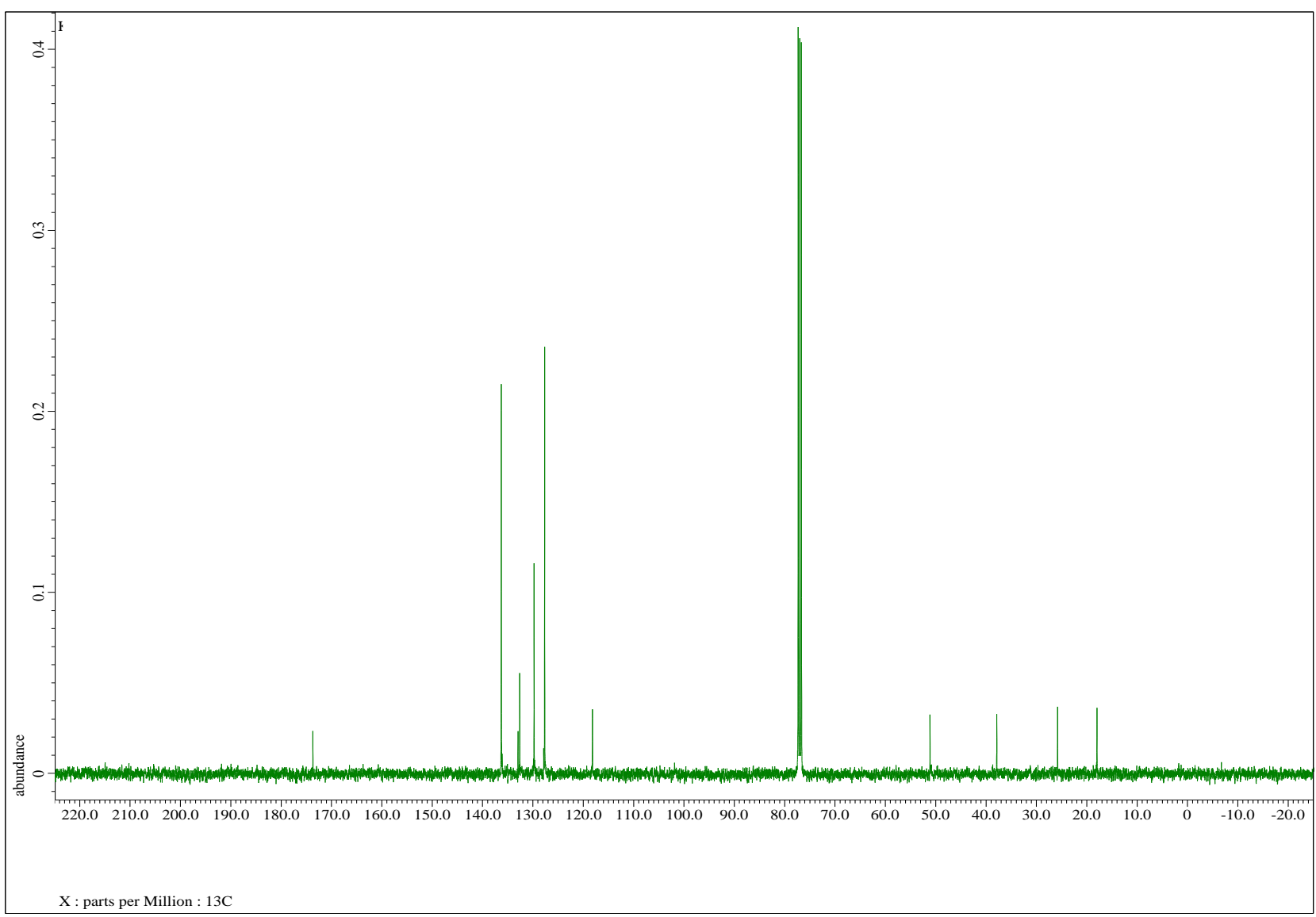

Figure $\mathbf{S 4 2 .}{ }^{13} \mathrm{C}\left\{{ }^{1} \mathrm{H}\right\}$ NMR spectra of methyl 4-methyl-2-(triphenylsilyl)pent-3-enoate (5ac) in $\mathrm{CDCl}_{3}$ 


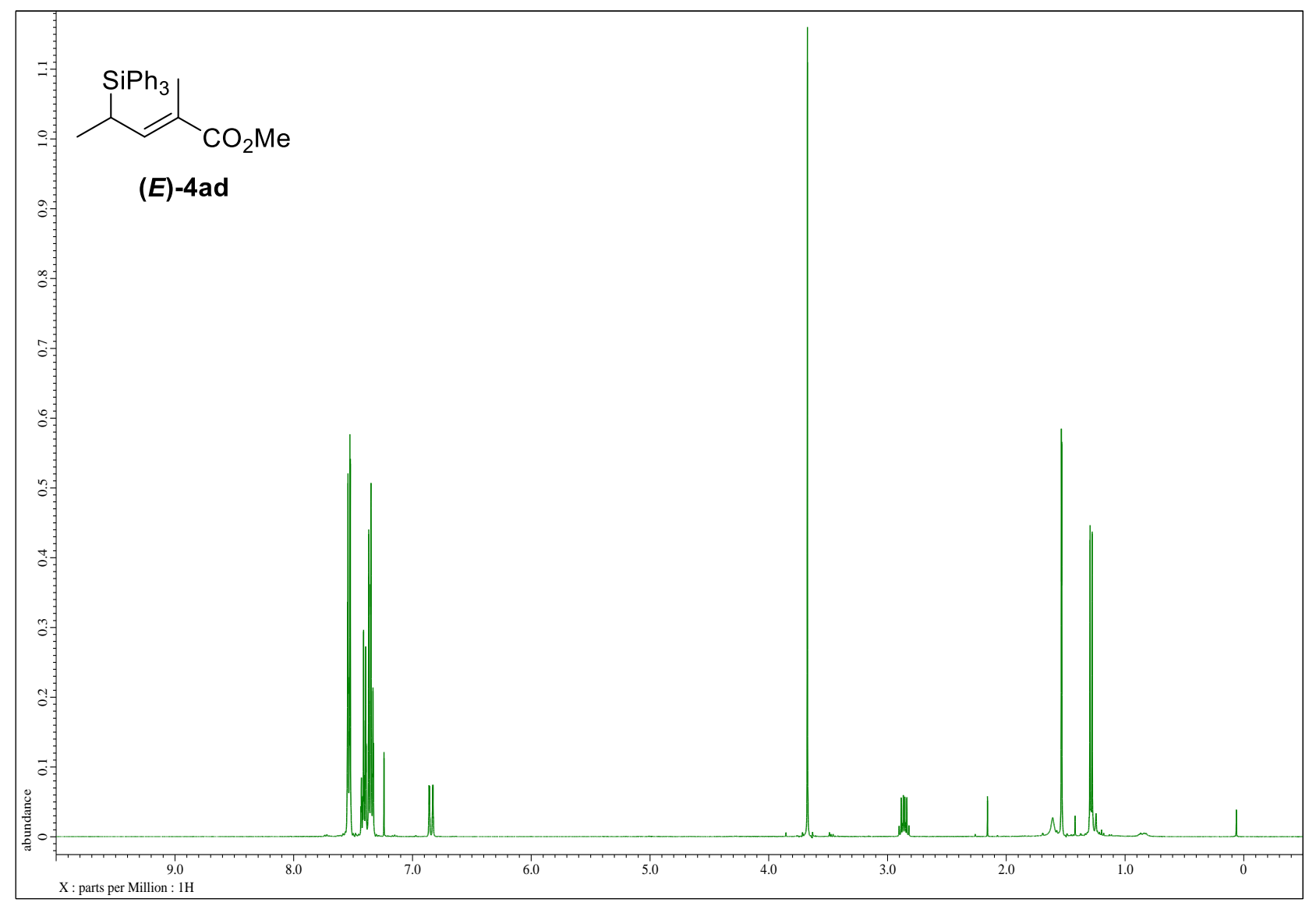

Figure S43. ${ }^{1} \mathrm{H}$ NMR spectra of methyl $(E)$-2-methyl-4-(triphenylsilyl)pent-2-enoate $((E)-4$ ad $)$ in $\mathrm{CDCl}_{3}$

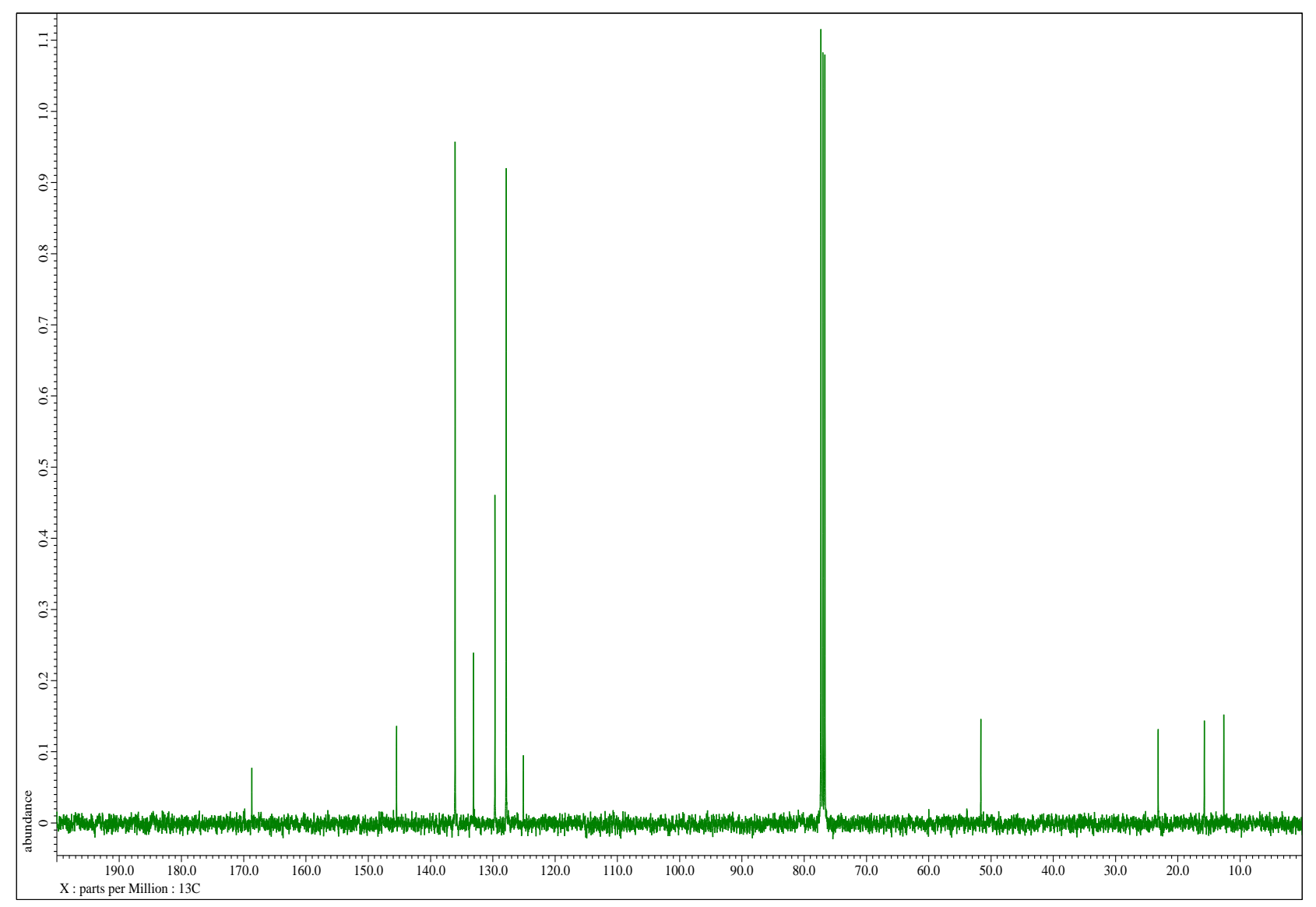

Figure S44. ${ }^{13} \mathrm{C}\left\{{ }^{1} \mathrm{H}\right\}$ NMR spectra of methyl $(E)$-2-methyl-4-(triphenylsilyl)pent-2-enoate ((E)-4ad) in $\mathrm{CDCl}_{3}$ 


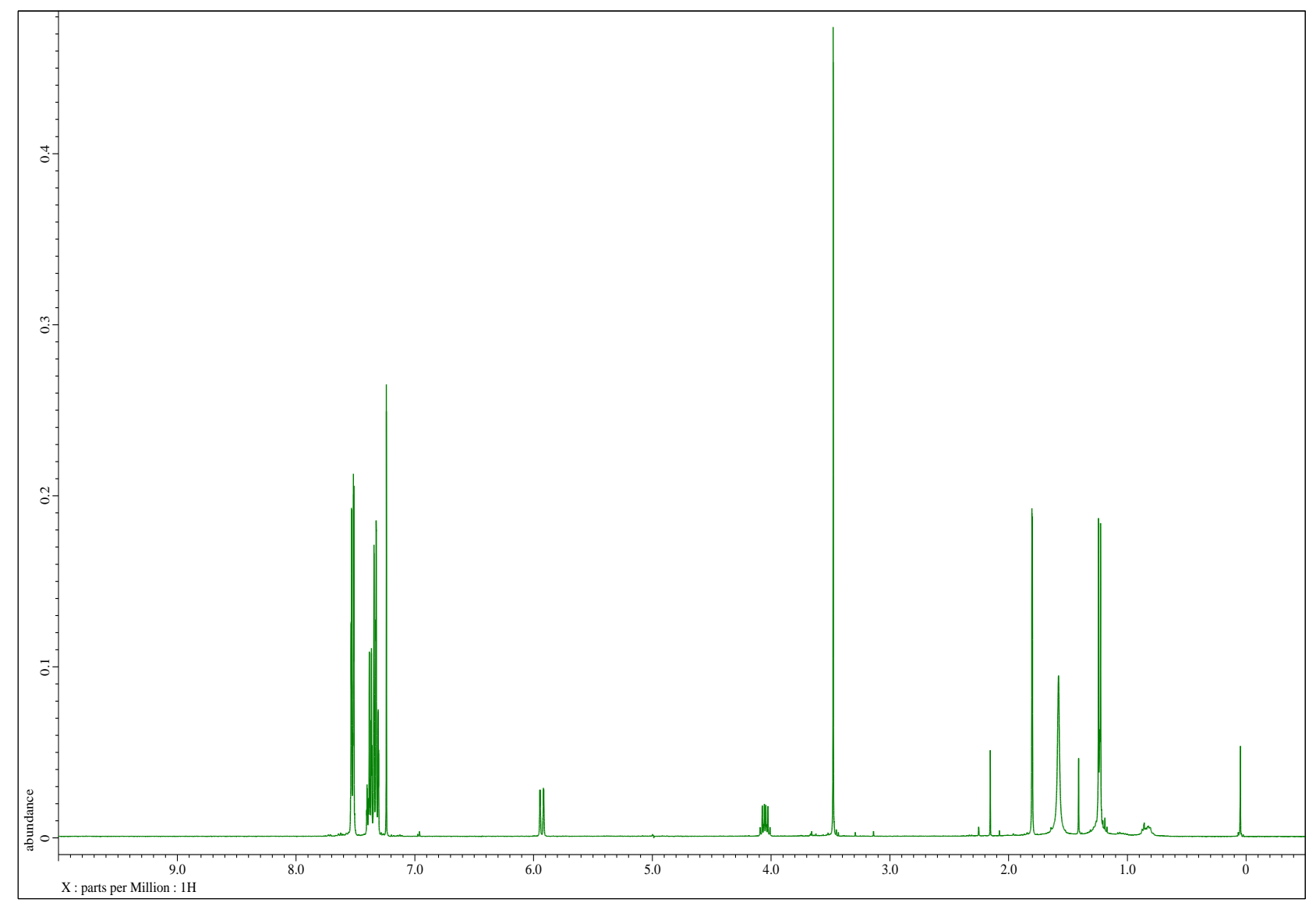

Figure S45. ${ }^{1} \mathrm{H}$ NMR spectra of methyl (Z)-2-methyl-4-(triphenylsilyl)pent-2-enoate ((Z)-4ad) in $\mathrm{CDCl}_{3}$

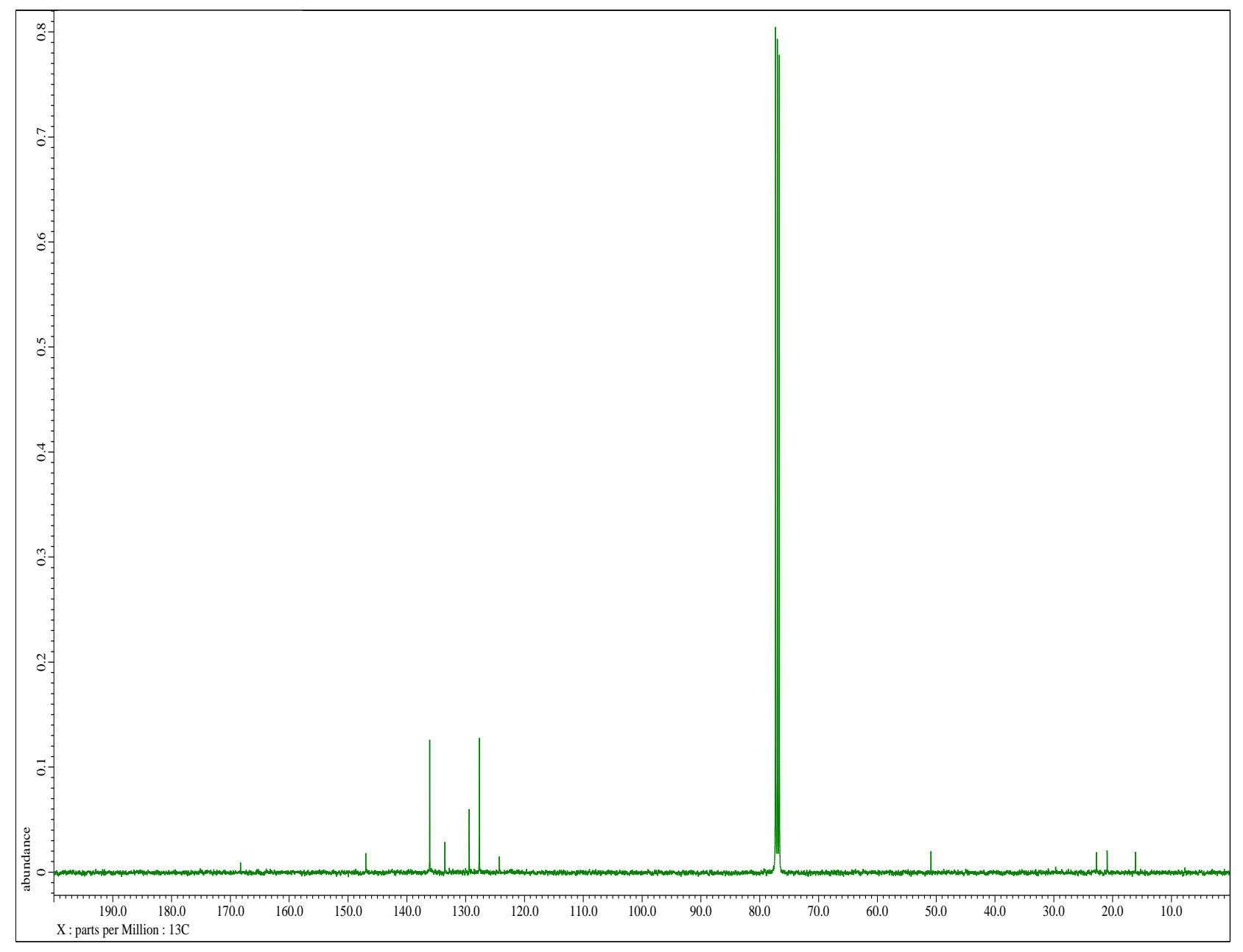

Figure S46. ${ }^{13} \mathrm{C}\left\{{ }^{1} \mathrm{H}\right\}$ NMR spectra of methyl $(Z)$-2-methyl-4-(triphenylsilyl)pent-2-enoate ((Z)-4ad) in $\mathrm{CDCl}_{3}$ 


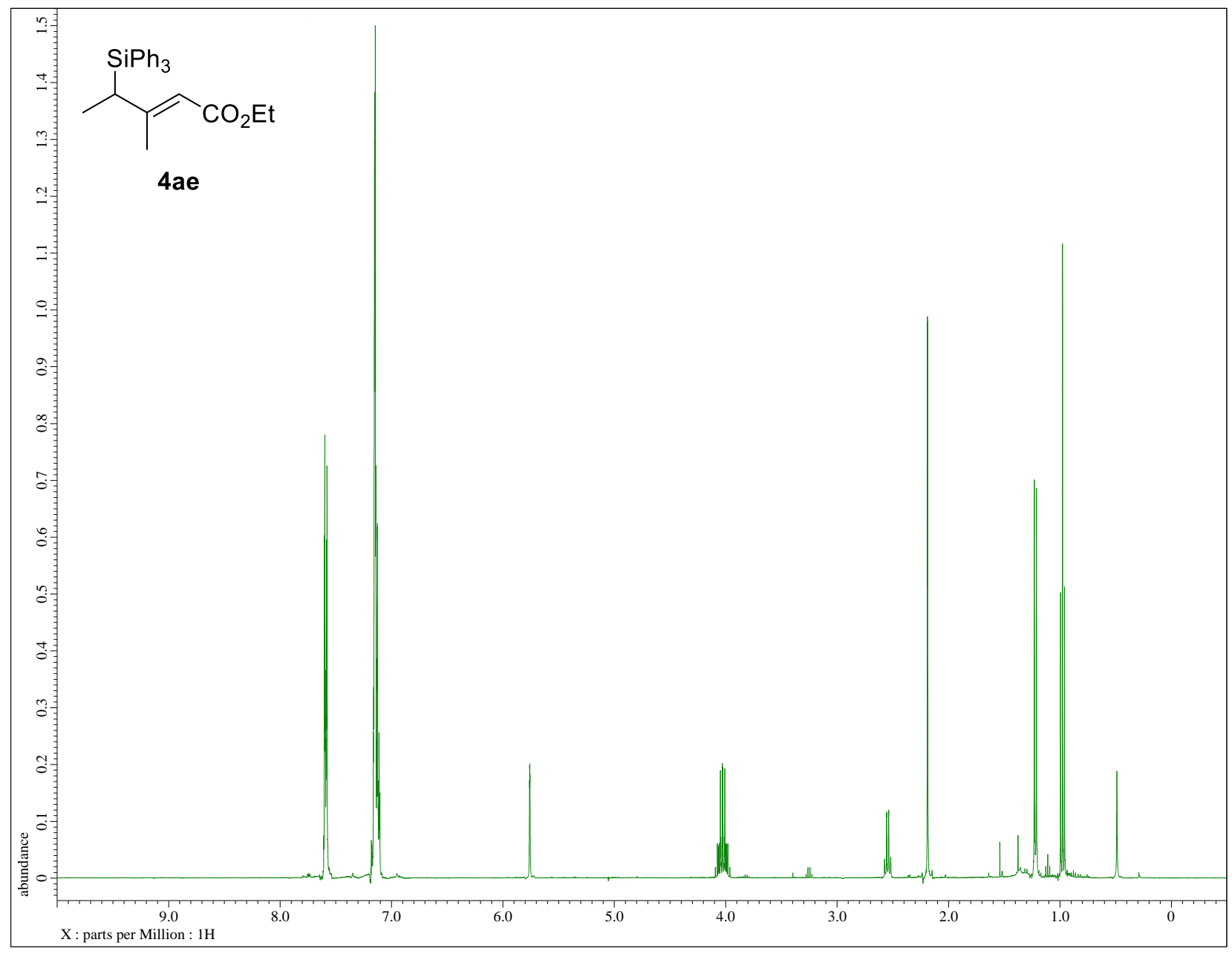

Figure S47. ${ }^{1} \mathrm{H}$ NMR spectra of ethyl (E)-3-methyl-4-(triphenylsilyl)pent-2-enoate (4ae) in $\mathrm{C}_{6} \mathrm{D}_{6}$

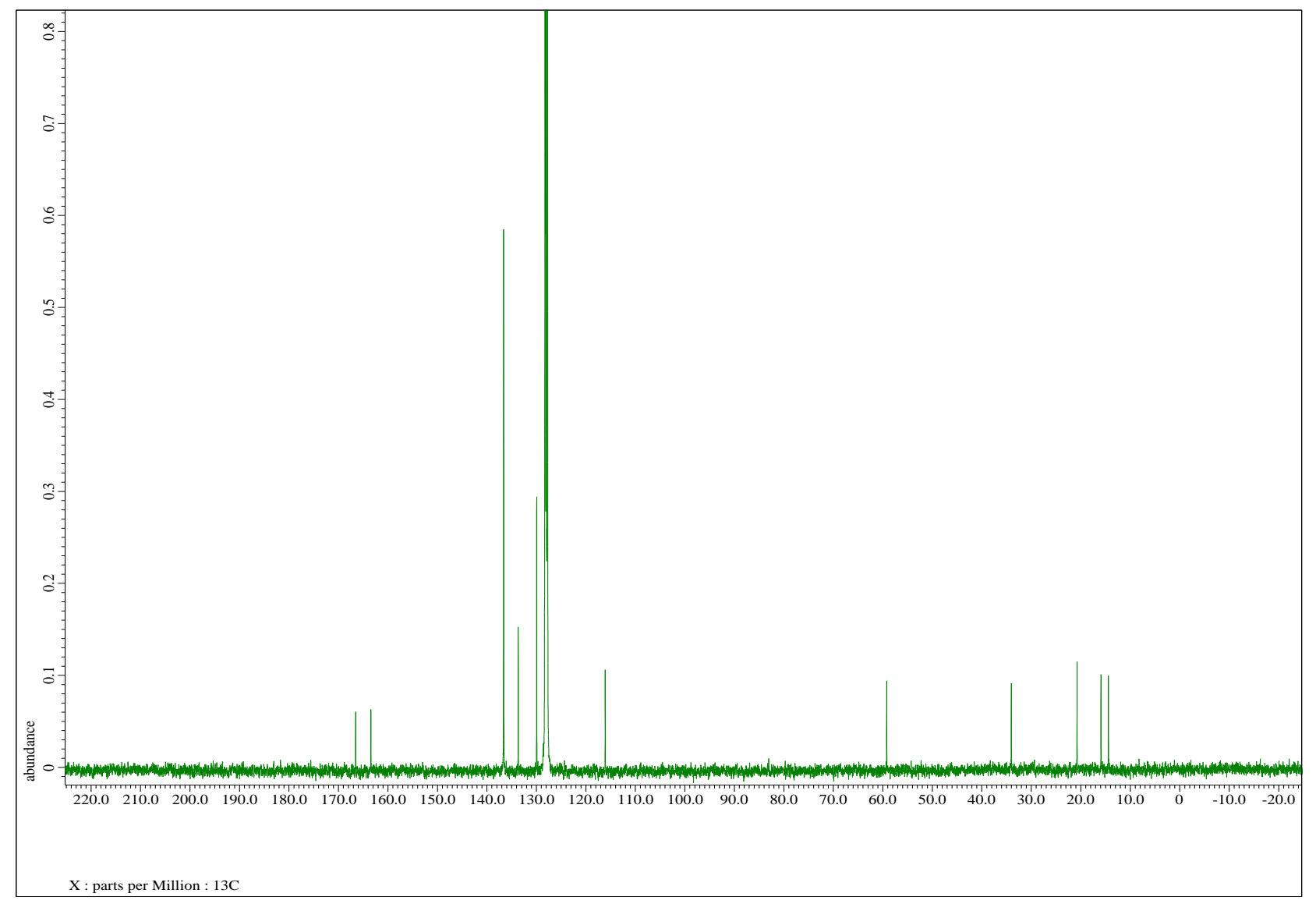

Figure S48. ${ }^{13} \mathrm{C}\left\{{ }^{1} \mathrm{H}\right\}$ NMR spectra of ethyl (E)-3-methyl-4-(triphenylsilyl)pent-2-enoate (4ae) in $\mathrm{C}_{6} \mathrm{D}_{6}$ 


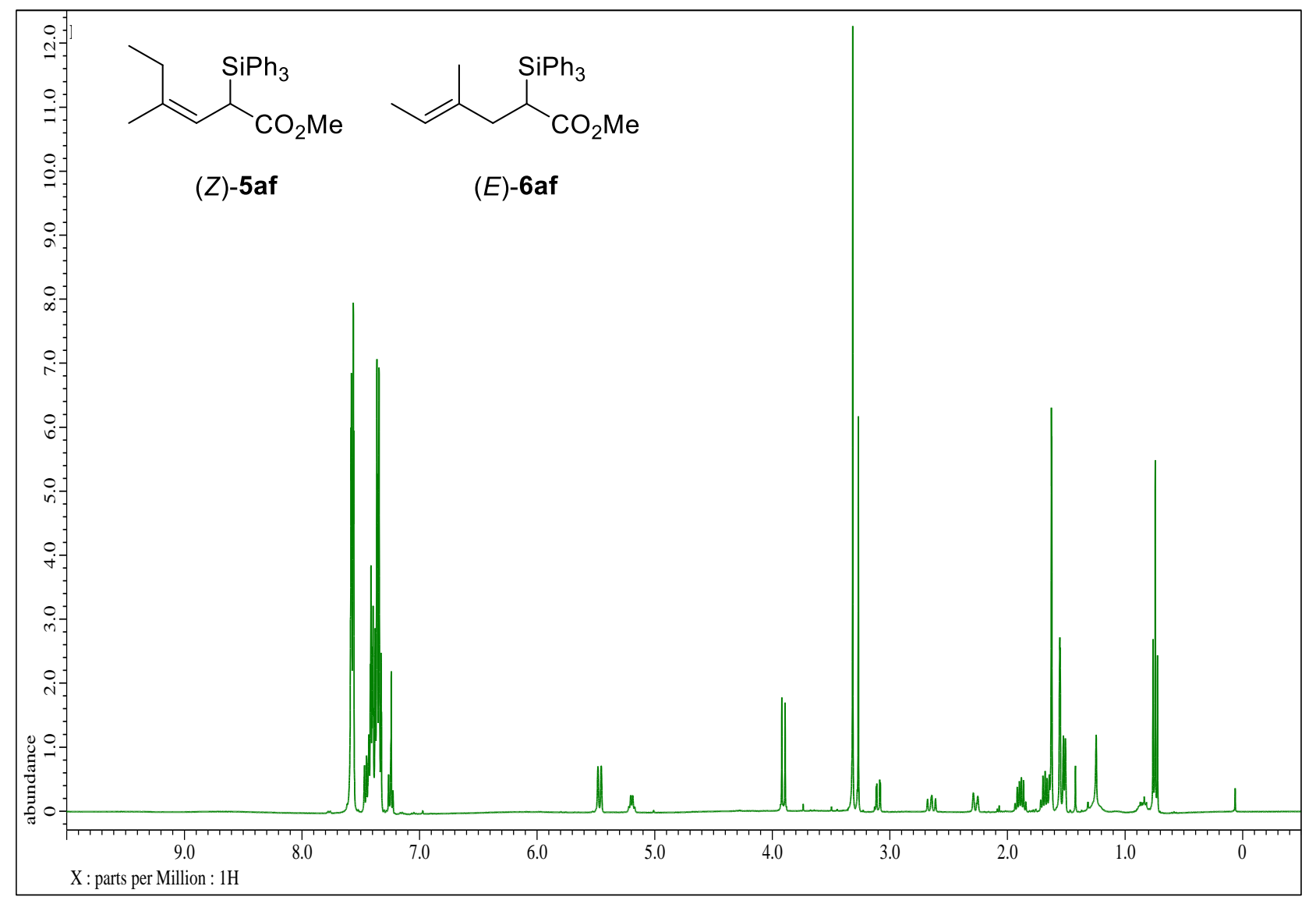

Figure S49. ${ }^{1} \mathrm{H}$ NMR spectra of methyl (Z)-4-methyl-2-(triphenylsilyl)hex-3-enoate (5af) and methyl (E)-4methyl-2-(triphenylsilyl)hex-4-enoate (6af)

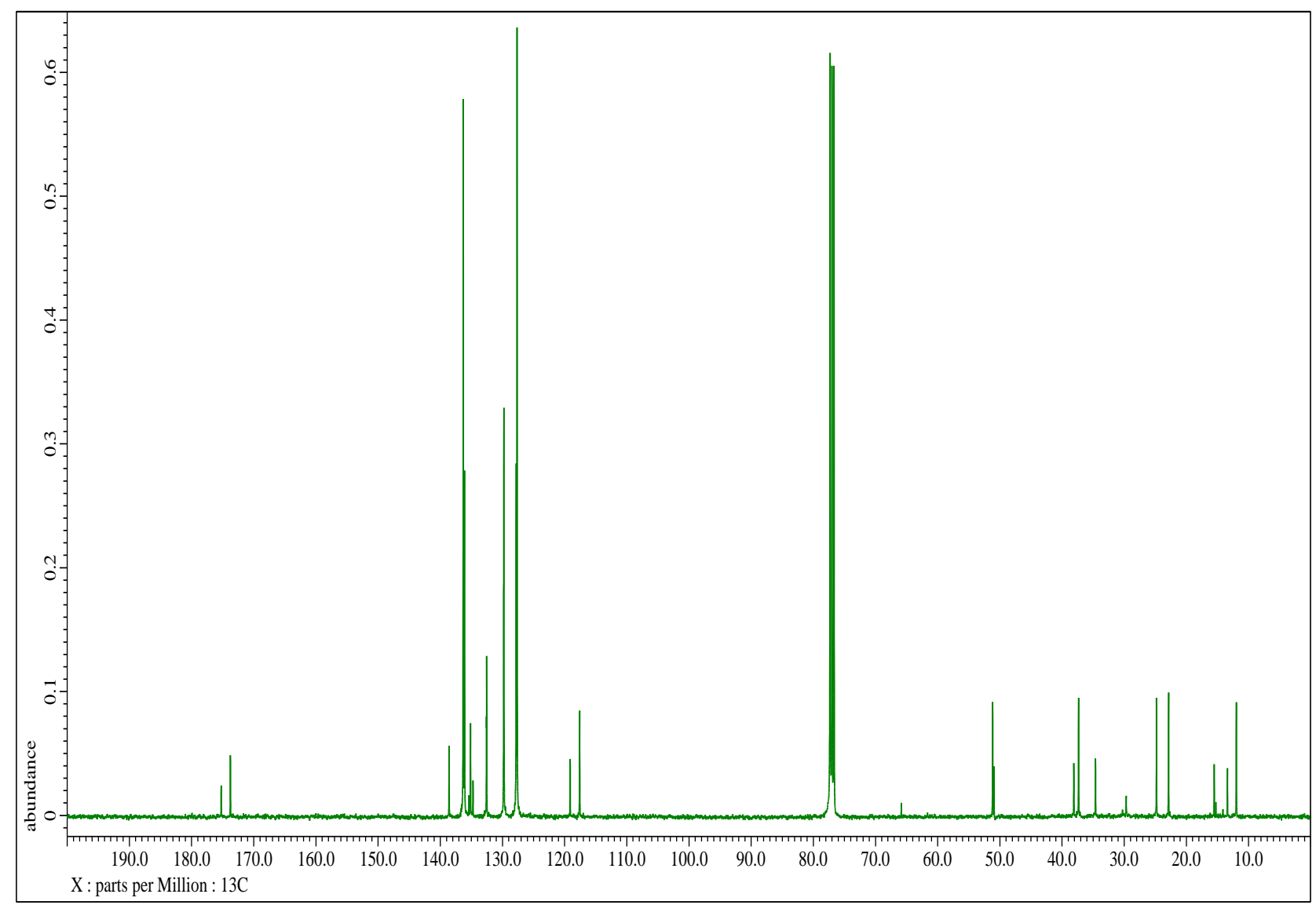

Figure S50. ${ }^{13} \mathrm{C}\left\{{ }^{1} \mathrm{H}\right\}$ NMR spectra of methyl (Z)-4-methyl-2-(triphenylsilyl)hex-3-enoate (5af) and methyl (E)-4-methyl-2-(triphenylsilyl)hex-4-enoate (6af) 


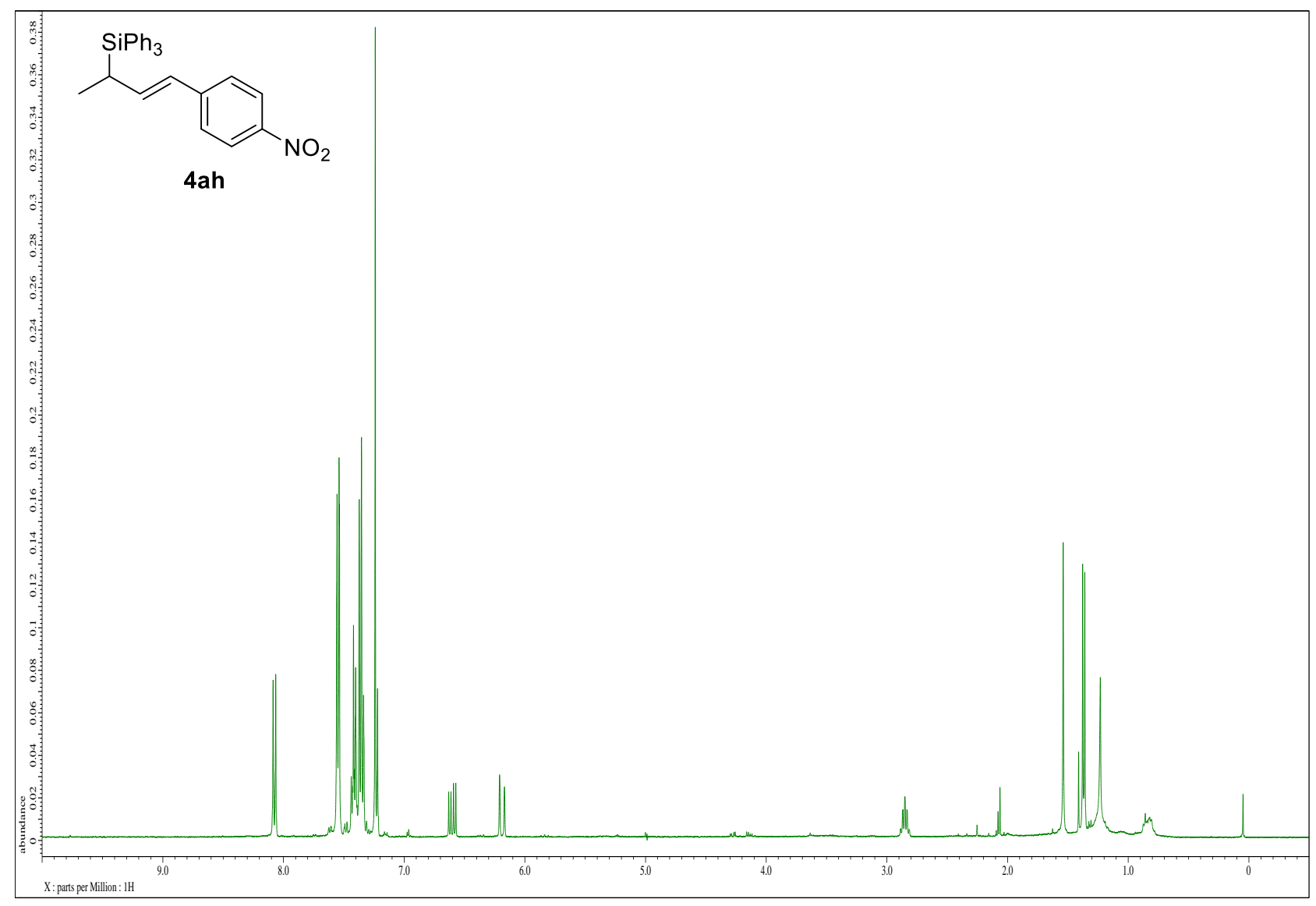

Figure S51. ${ }^{1} \mathrm{H}$ NMR spectra of (E)-(4-(4-nitrophenyl)but-3-en-2-yl)triphenylsilane (4ah) in $\mathrm{CDCl}_{3}$

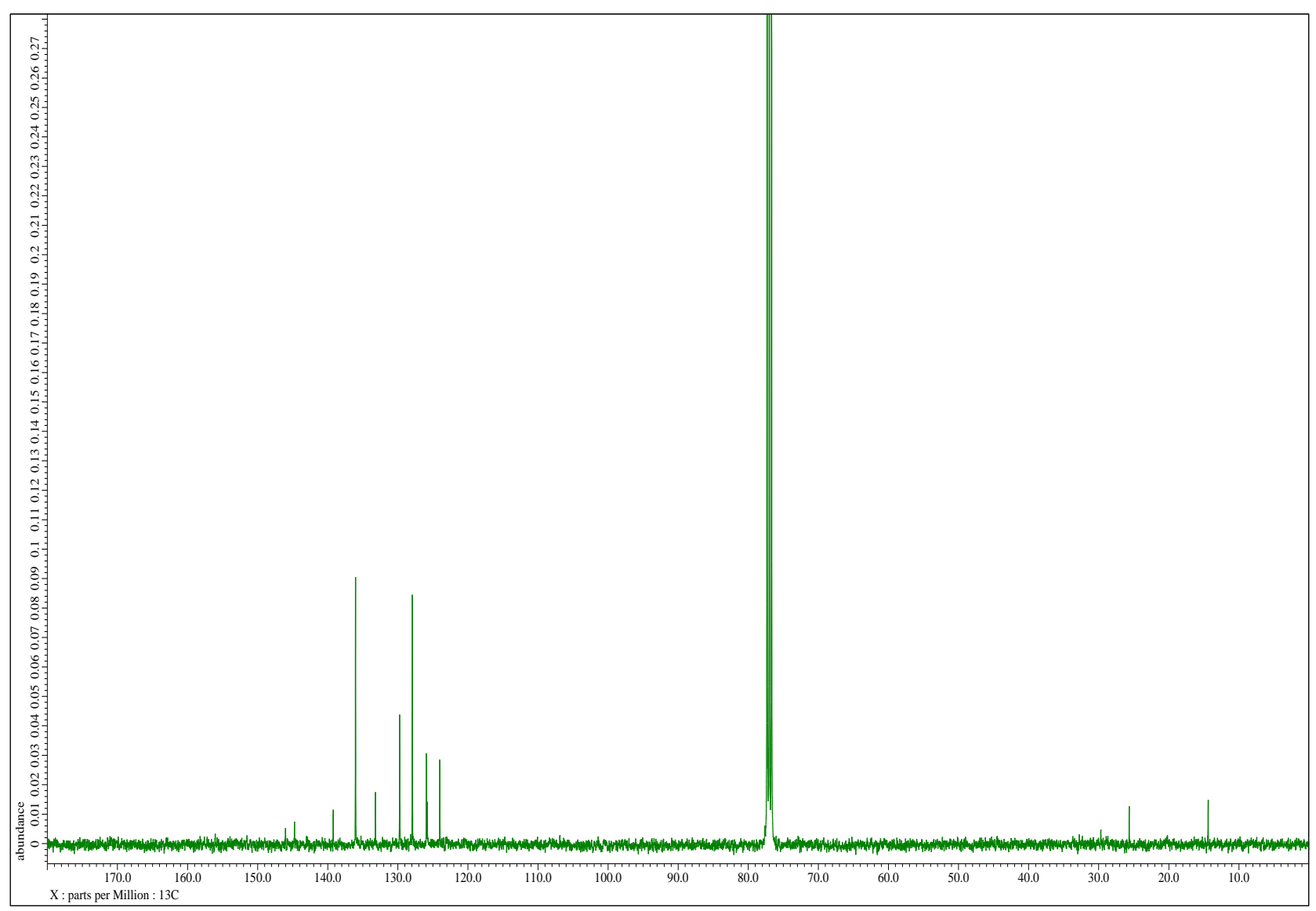

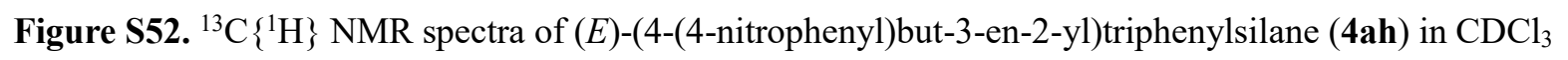




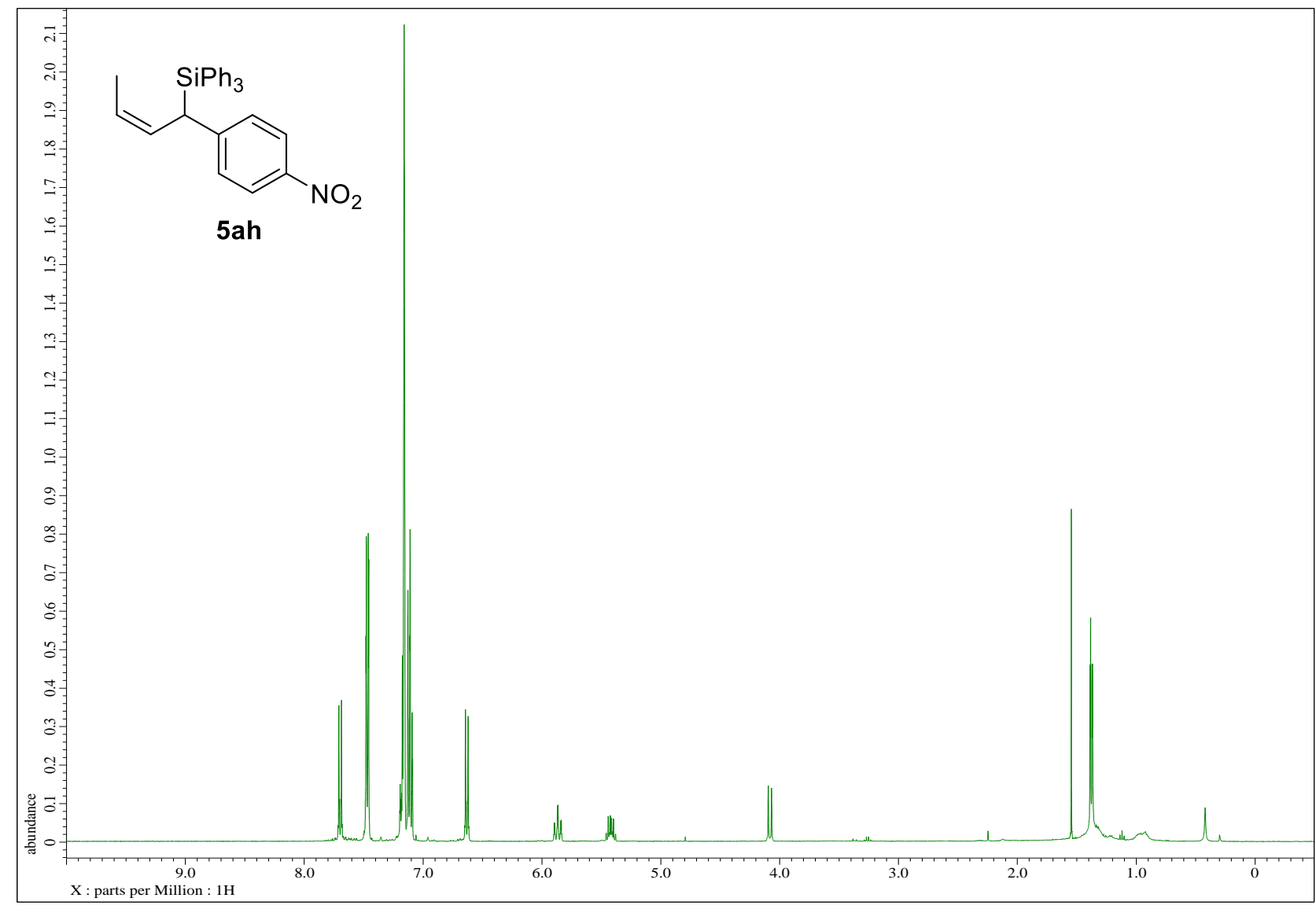

Figure S53. ${ }^{1} \mathrm{H}$ NMR spectra of (Z)-(1-(4-nitrophenyl)but-2-en-1-yl)triphenylsilane (5ah) in $\mathrm{C}_{6} \mathrm{D}_{6}$

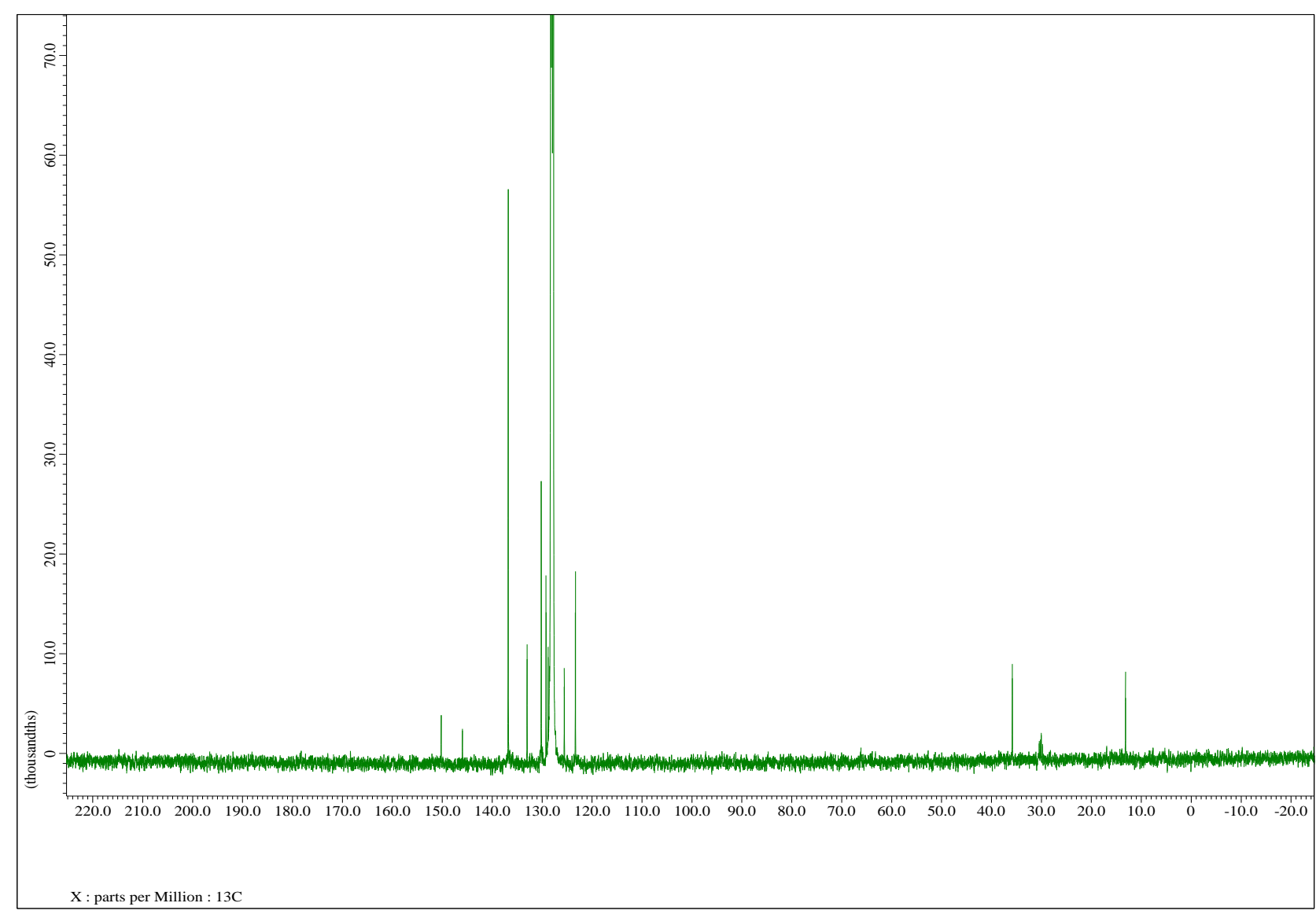

Figure S54. ${ }^{13} \mathrm{C}\left\{{ }^{1} \mathrm{H}\right\}$ NMR spectra of (Z)-(1-(4-nitrophenyl)but-2-en-1-yl)triphenylsilane (5ah) in $\mathrm{C}_{6} \mathrm{D}_{6}$ 


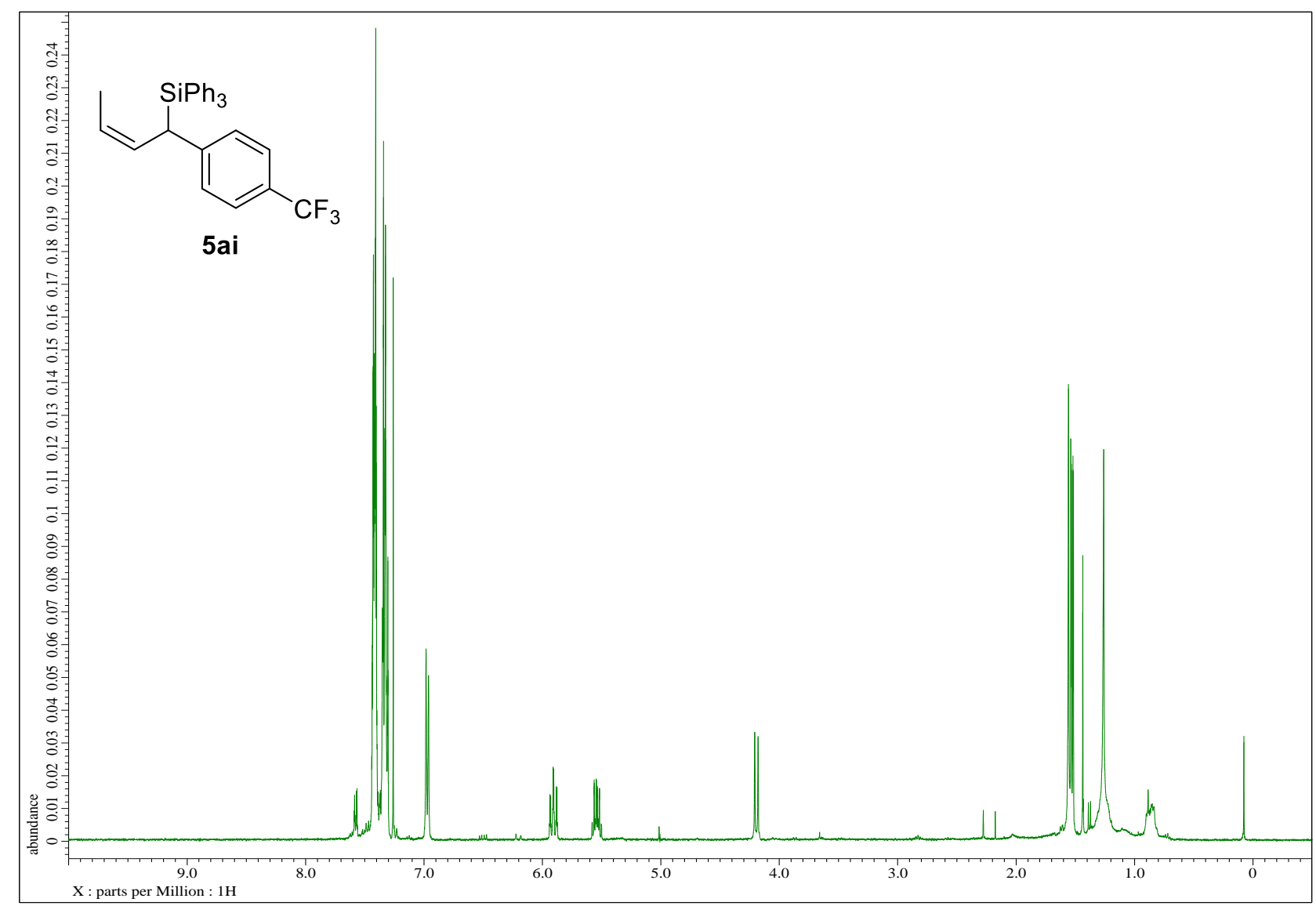

Figure S55. ${ }^{1} \mathrm{H}$ NMR spectra of (Z)-triphenyl(1-(4-(trifluoromethyl)phenyl)but-2-en-1-yl)silane (5ai) in $\mathrm{CDCl}_{3}$

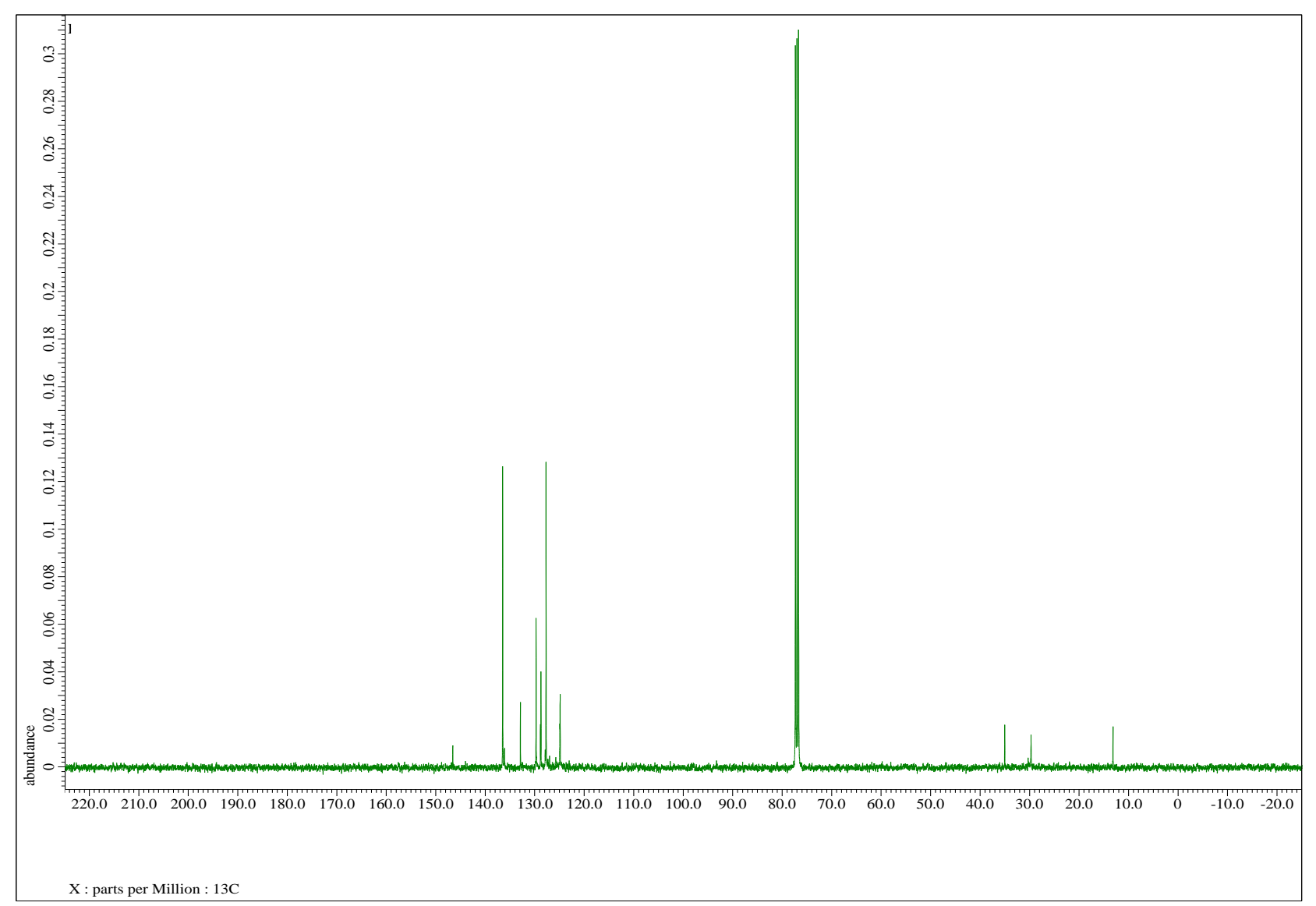

Figure S56. ${ }^{13} \mathrm{C}\left\{{ }^{1} \mathrm{H}\right\}$ spectra of (Z)-triphenyl(1-(4-(trifluoromethyl)phenyl)but-2-en-1-yl)silane (5ai) in $\mathrm{CDCl}_{3}$ 


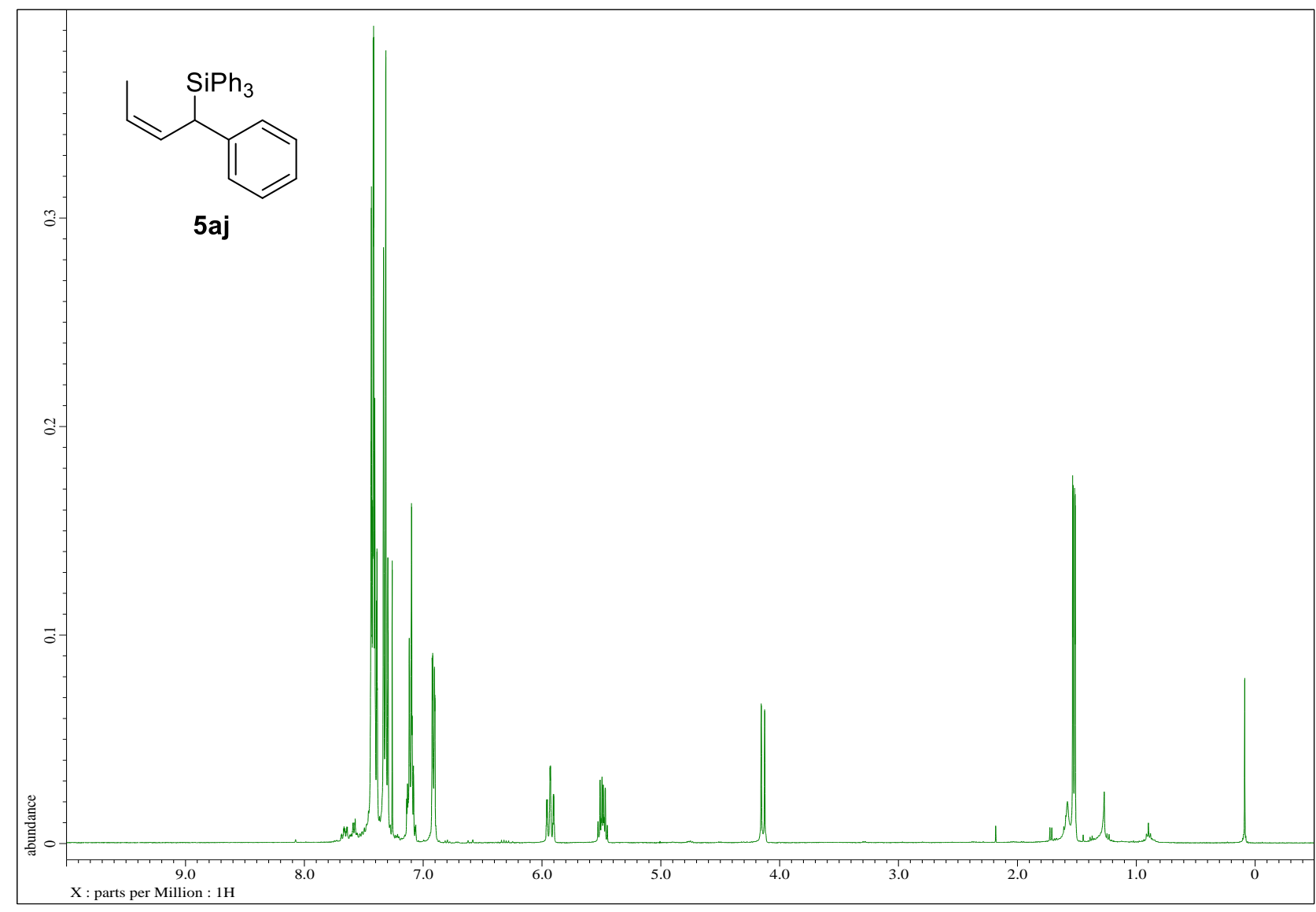

Figure S57. ${ }^{1} \mathrm{H}$ NMR spectra of (Z)-triphenyl(1-phenylbut-2-en-1-yl)silane (5aj) in $\mathrm{CDCl}_{3}$

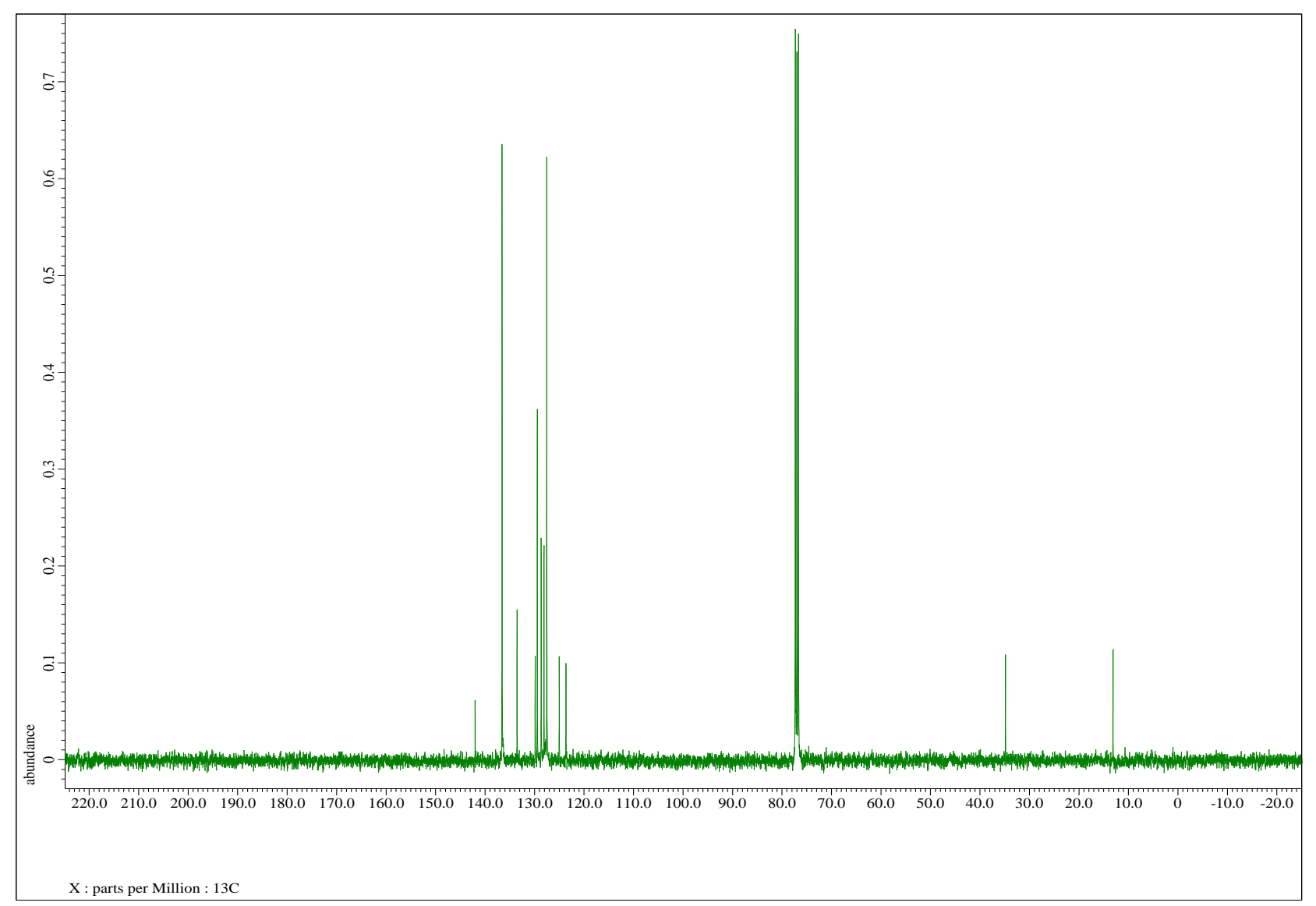

Figure S58. ${ }^{13} \mathrm{C}\left\{{ }^{1} \mathrm{H}\right\}$ NMR spectra of (Z)-triphenyl(1-phenylbut-2-en-1-yl)silane (5aj) in $\mathrm{CDCl}_{3}$ 


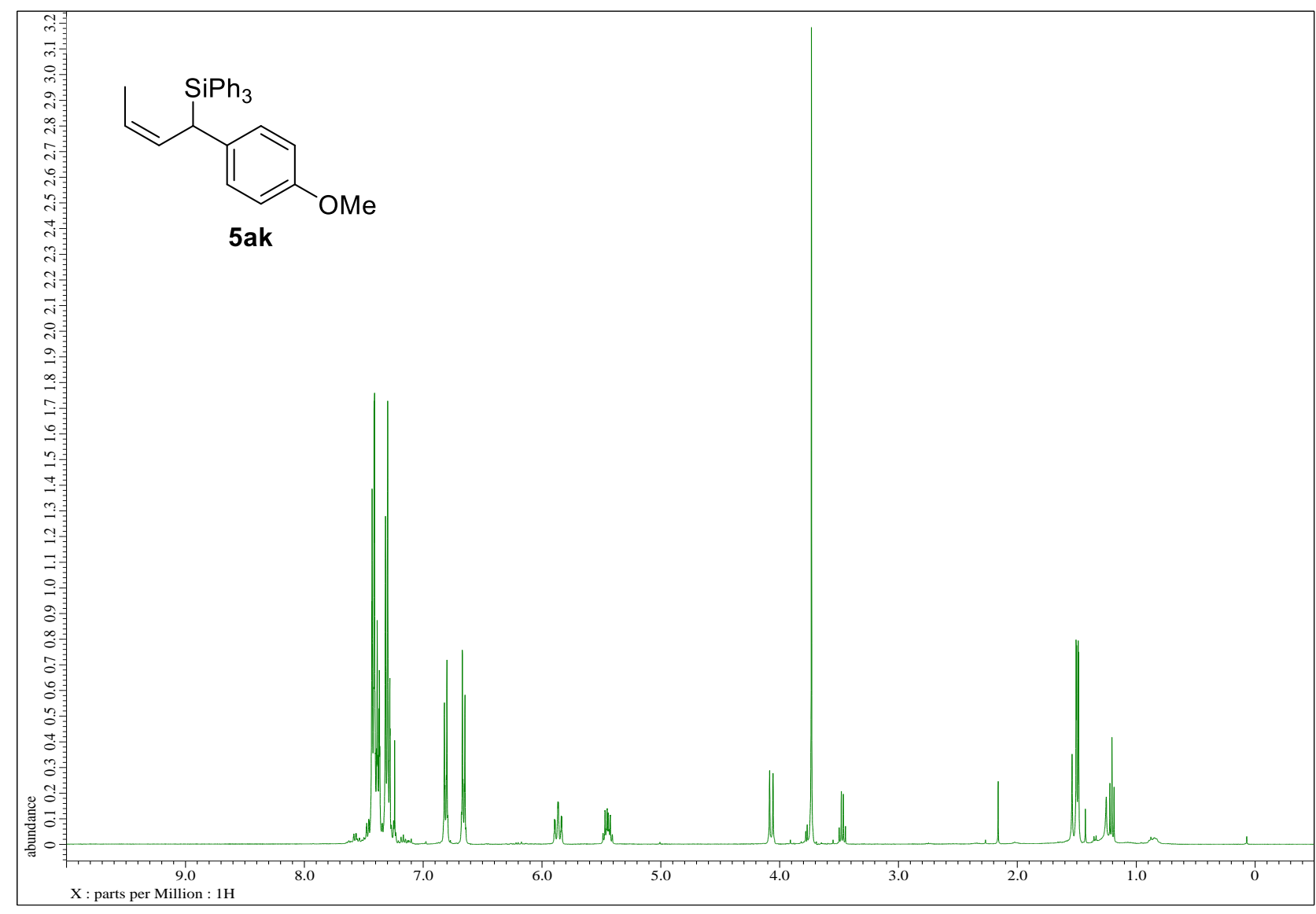

Figure S59. ${ }^{1} \mathrm{H}$ NMR spectra of (Z)-(1-(4-methoxyphenyl)but-2-en-1-yl)triphenylsilane (5ak) in $\mathrm{CDCl}_{3}$

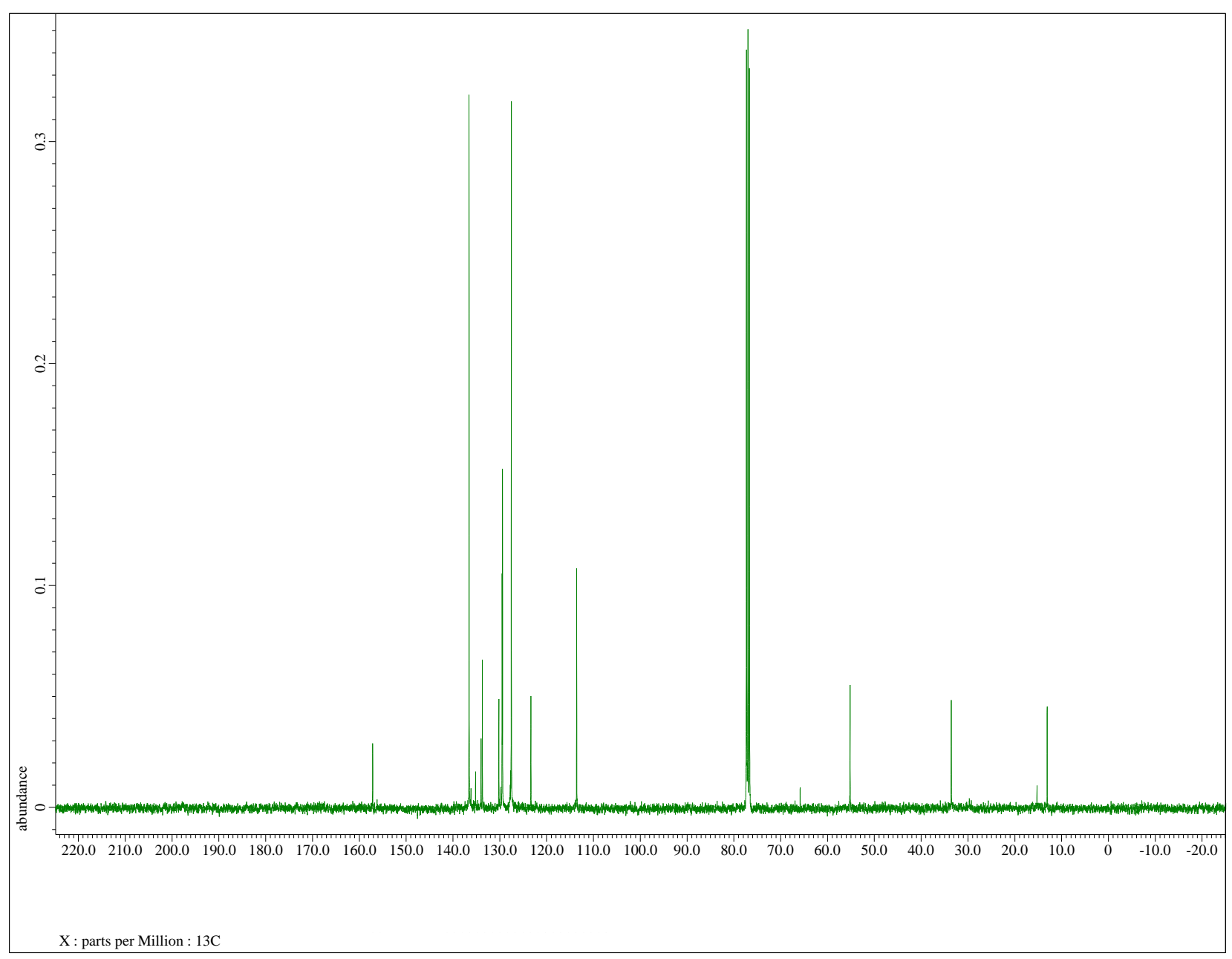

Figure S60. ${ }^{13} \mathrm{C}\left\{{ }^{1} \mathrm{H}\right\}$ spectra of $(Z)-(1-(4-m e t h o x y p h e n y l) b u t-2-e n-1-y l)$ triphenylsilane (5ak) in $\mathrm{CDCl}_{3}$ 


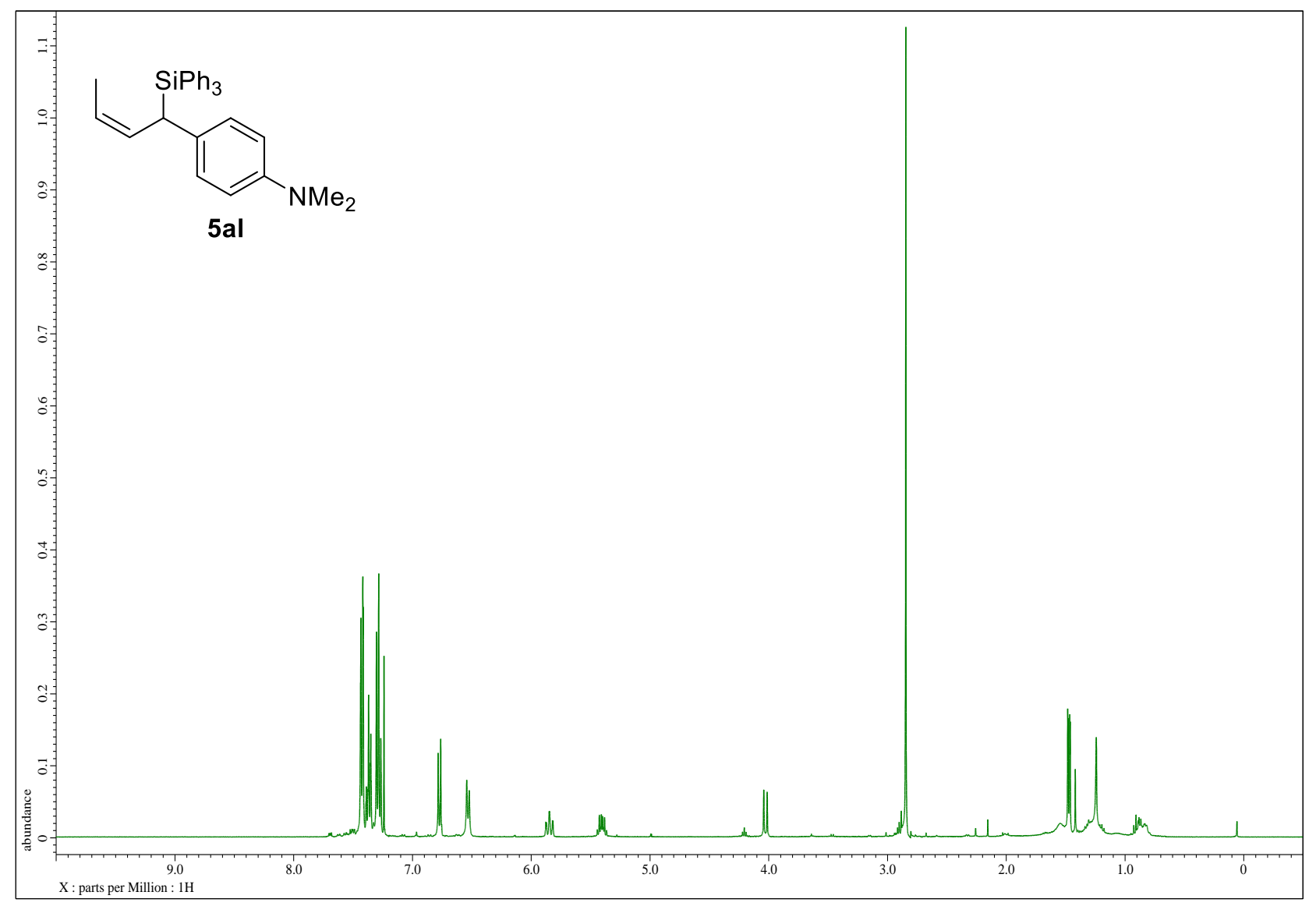

Figure S61. ${ }^{1} \mathrm{H}$ NMR spectra of (Z)- $N, N$-dimethyl-4-(1-(triphenylsilyl)but-2-en-1-yl)aniline ((Z)-5al) in $\mathrm{CDCl}_{3}$

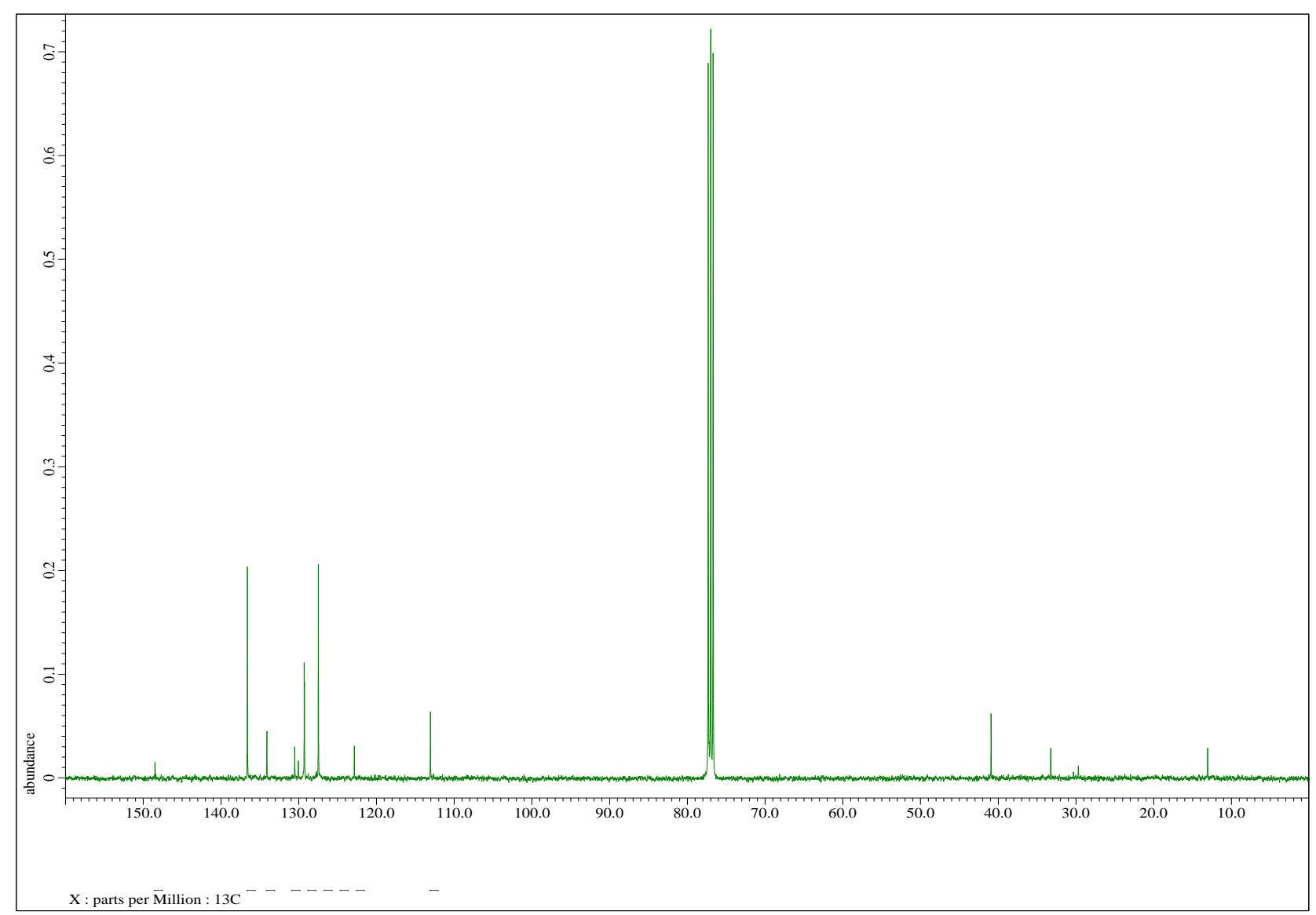

Figure S62. ${ }^{13} \mathrm{C}\left\{{ }^{1} \mathrm{H}\right\}$ spectra of (Z)- $N, N$-dimethyl-4-(1-(triphenylsilyl)but-2-en-1-yl)aniline ((Z)-5al) in $\mathrm{CDCl}_{3}$ 


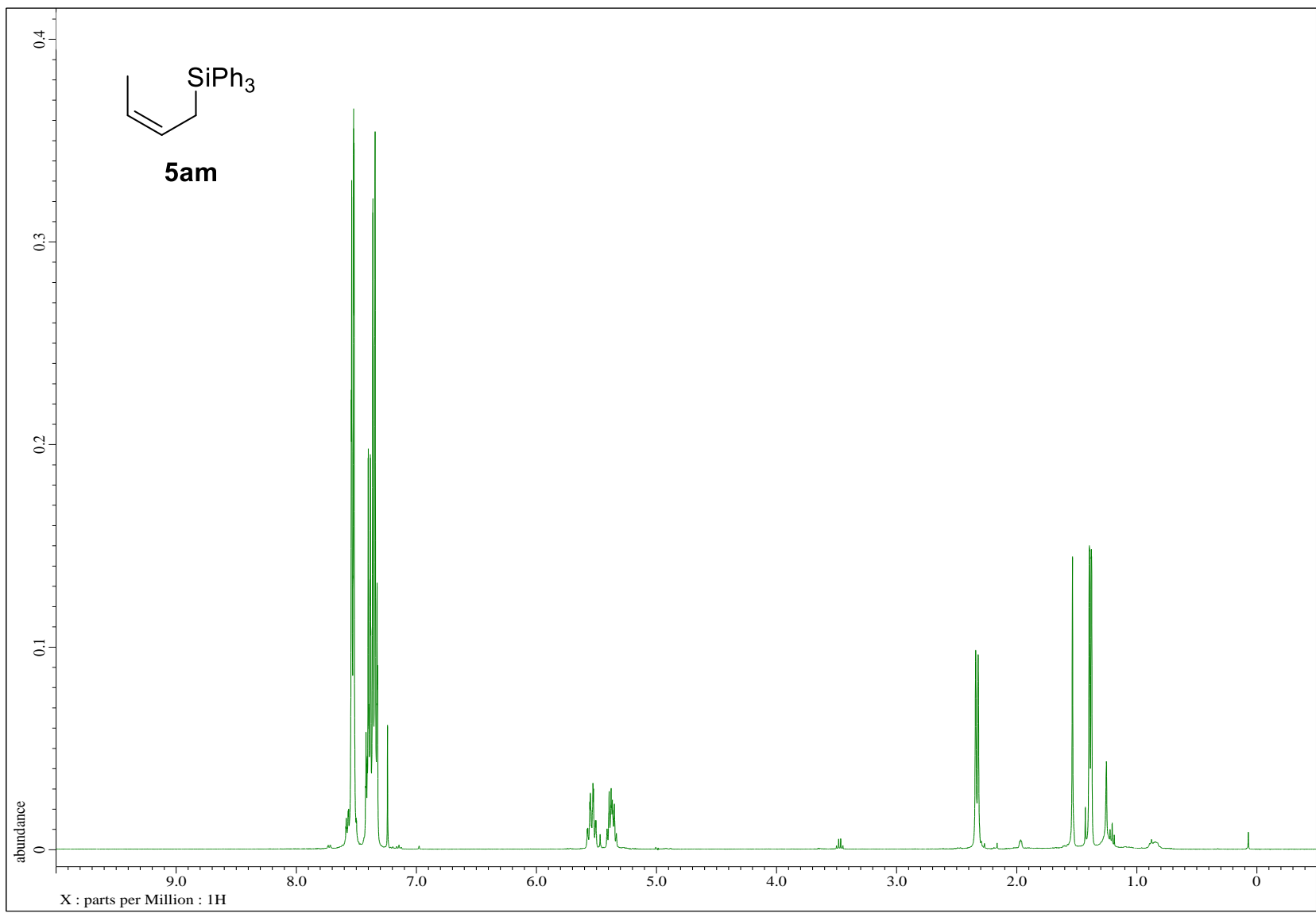

Figure S63. ${ }^{1} \mathrm{H}$ NMR spectra of (Z)-but-2-en-1-yltriphenylsilane (5am) in $\mathrm{CDCl}_{3}$

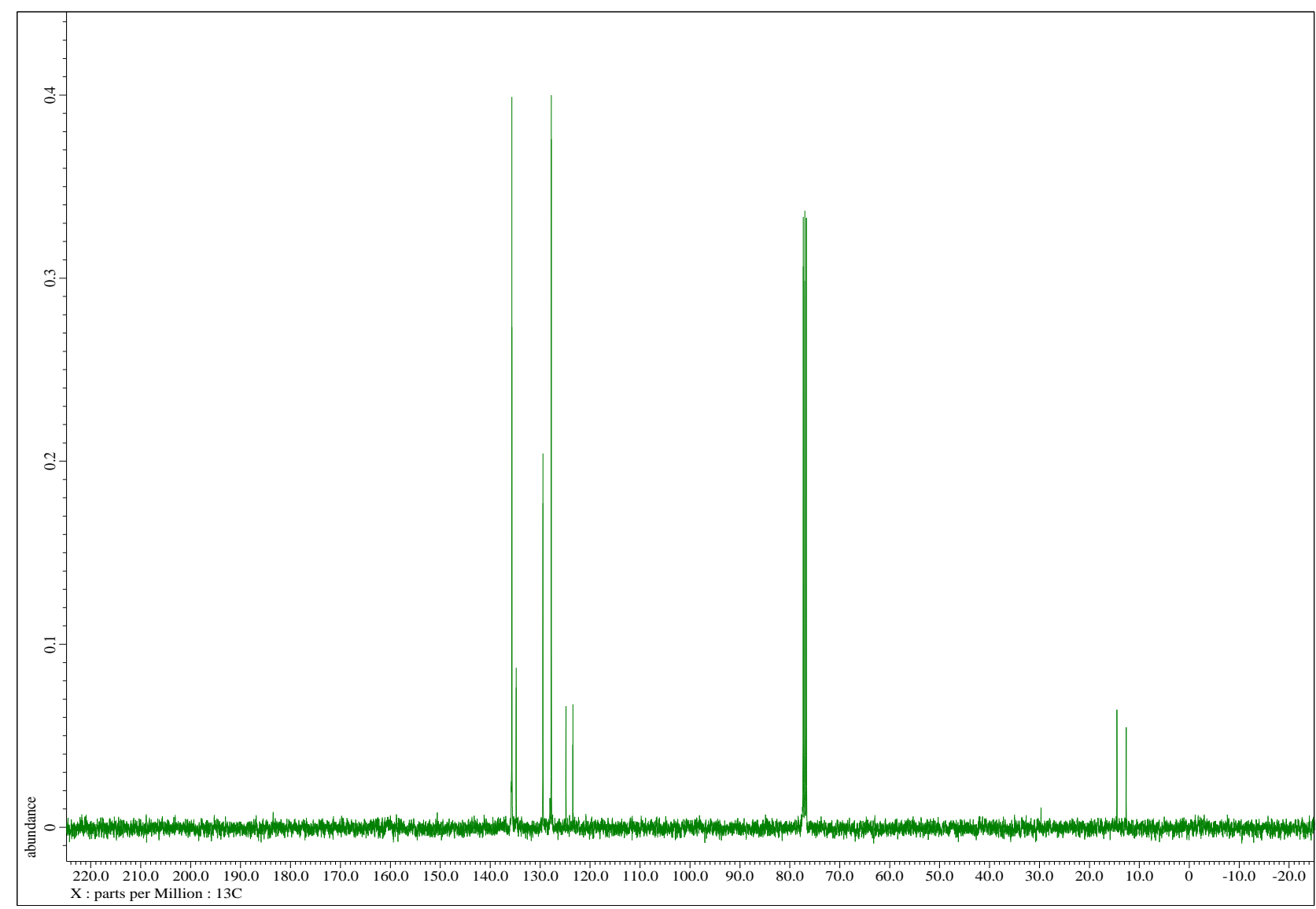

Figure S64. ${ }^{13} \mathrm{C}\left\{{ }^{1} \mathrm{H}\right\}$ NMR spectra of (Z)-but-2-en-1-yltriphenylsilane (5am) in $\mathrm{CDCl}_{3}$ 


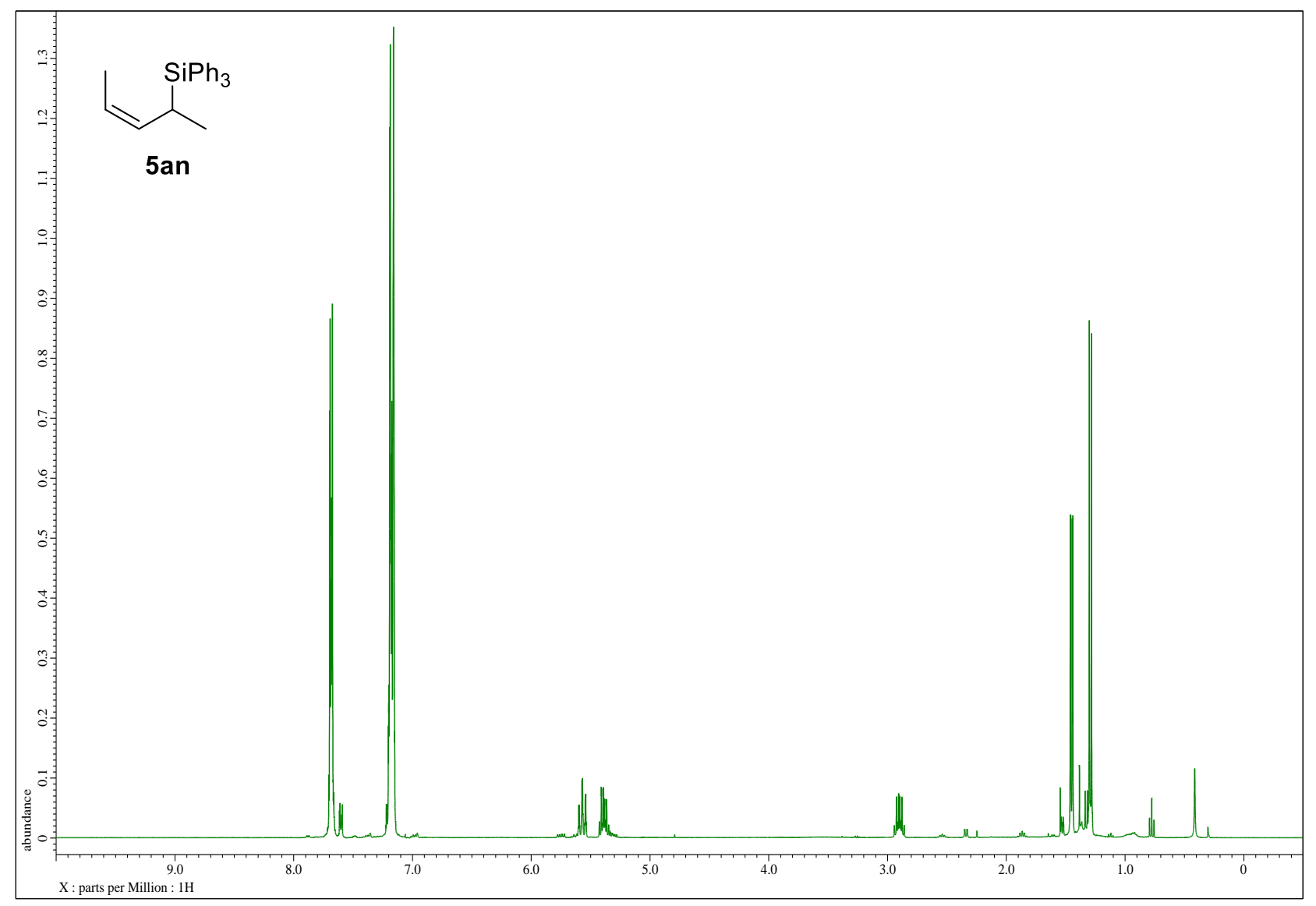

Figure S65. ${ }^{1} \mathrm{H}$ NMR spectra of (Z)-pent-3-en-2-yltriphenylsilane (5an) in $\mathrm{C}_{6} \mathrm{D}_{6}$

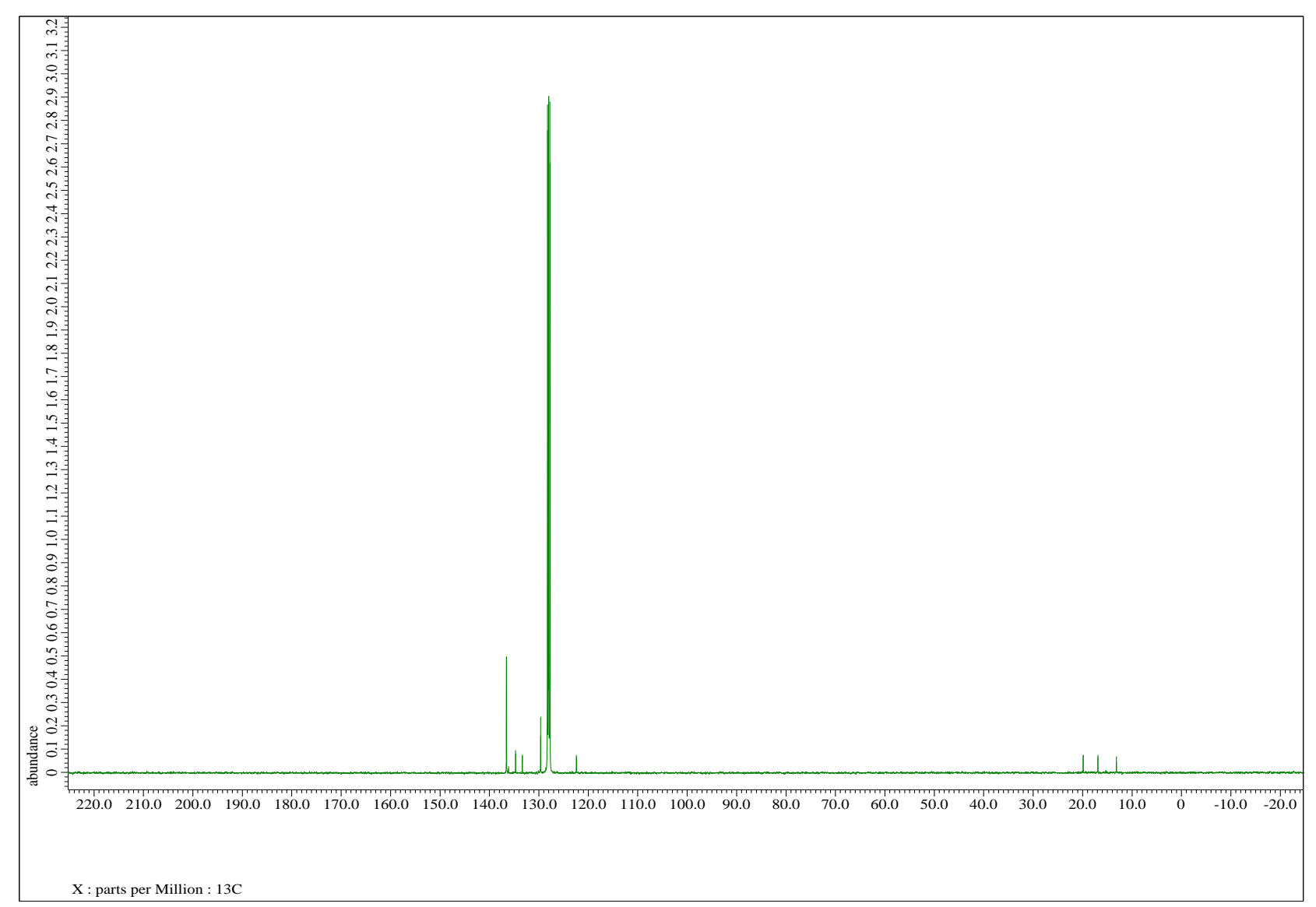

Figure S66. ${ }^{13} \mathrm{C}\left\{{ }^{1} \mathrm{H}\right\}$ NMR spectra of (Z)-pent-3-en-2-yltriphenylsilane (5an) in $\mathrm{C}_{6} \mathrm{D}_{6}$ 


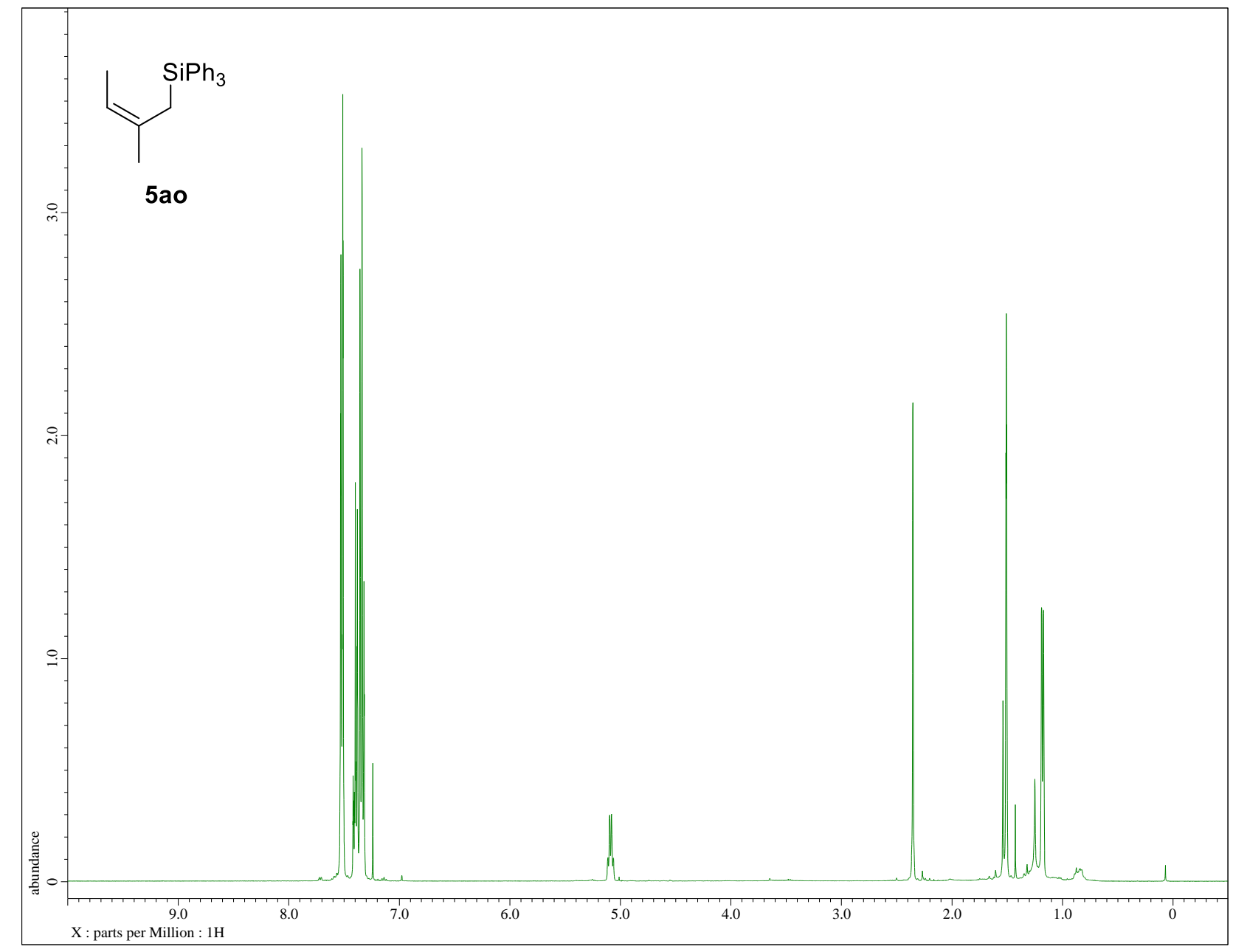

Figure S67. ${ }^{1} \mathrm{H}$ NMR spectra of (Z)-(2-Methylbut-2-en-1-yl)triphenylsilane (5ao) in $\mathrm{CDCl}_{3}$

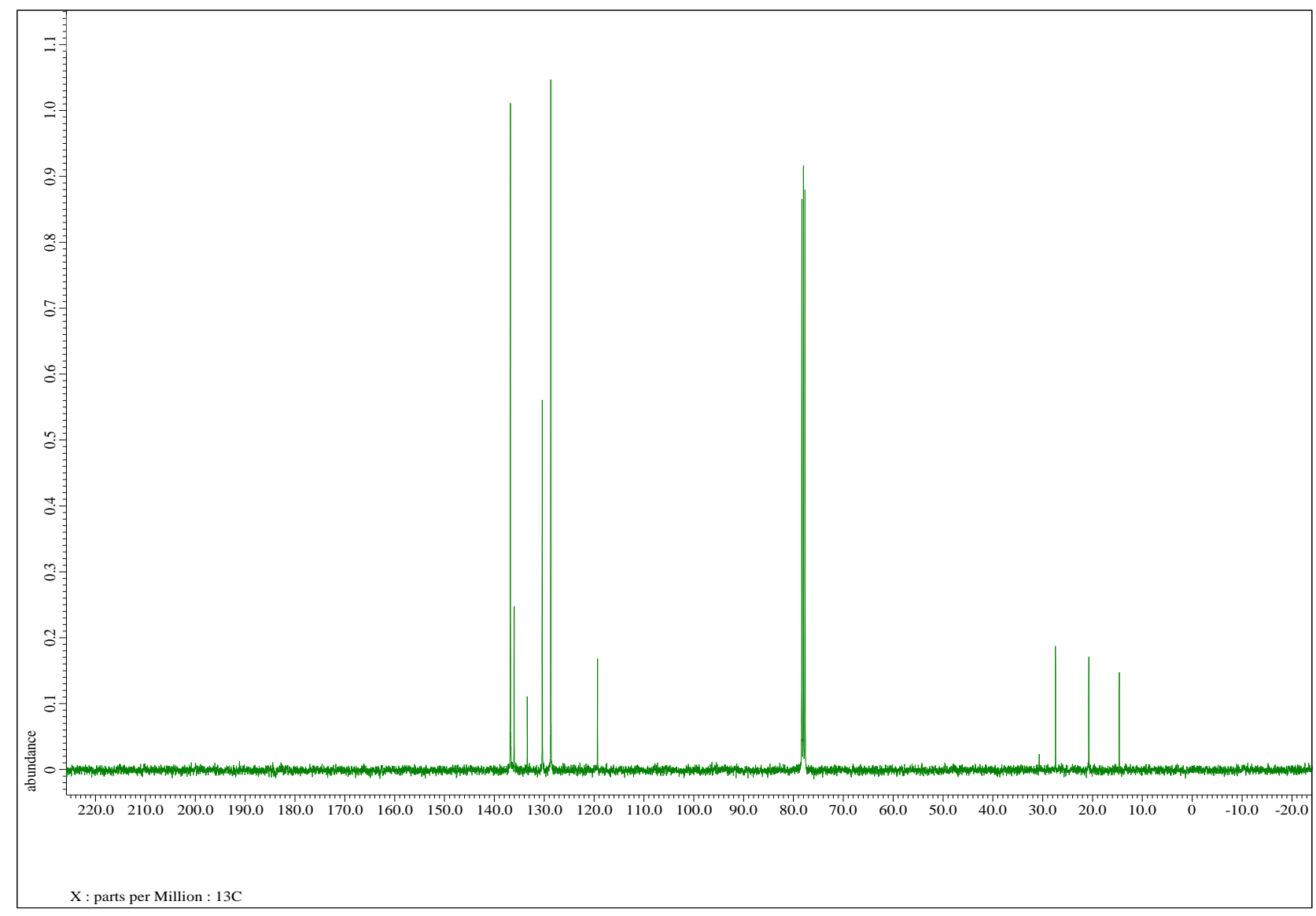

Figure S68. ${ }^{13} \mathrm{C}\left\{{ }^{1} \mathrm{H}\right\}$ NMR spectra of (Z)-(2-Methylbut-2-en-1-yl)triphenylsilane (5ao) in $\mathrm{CDCl}_{3}$ 


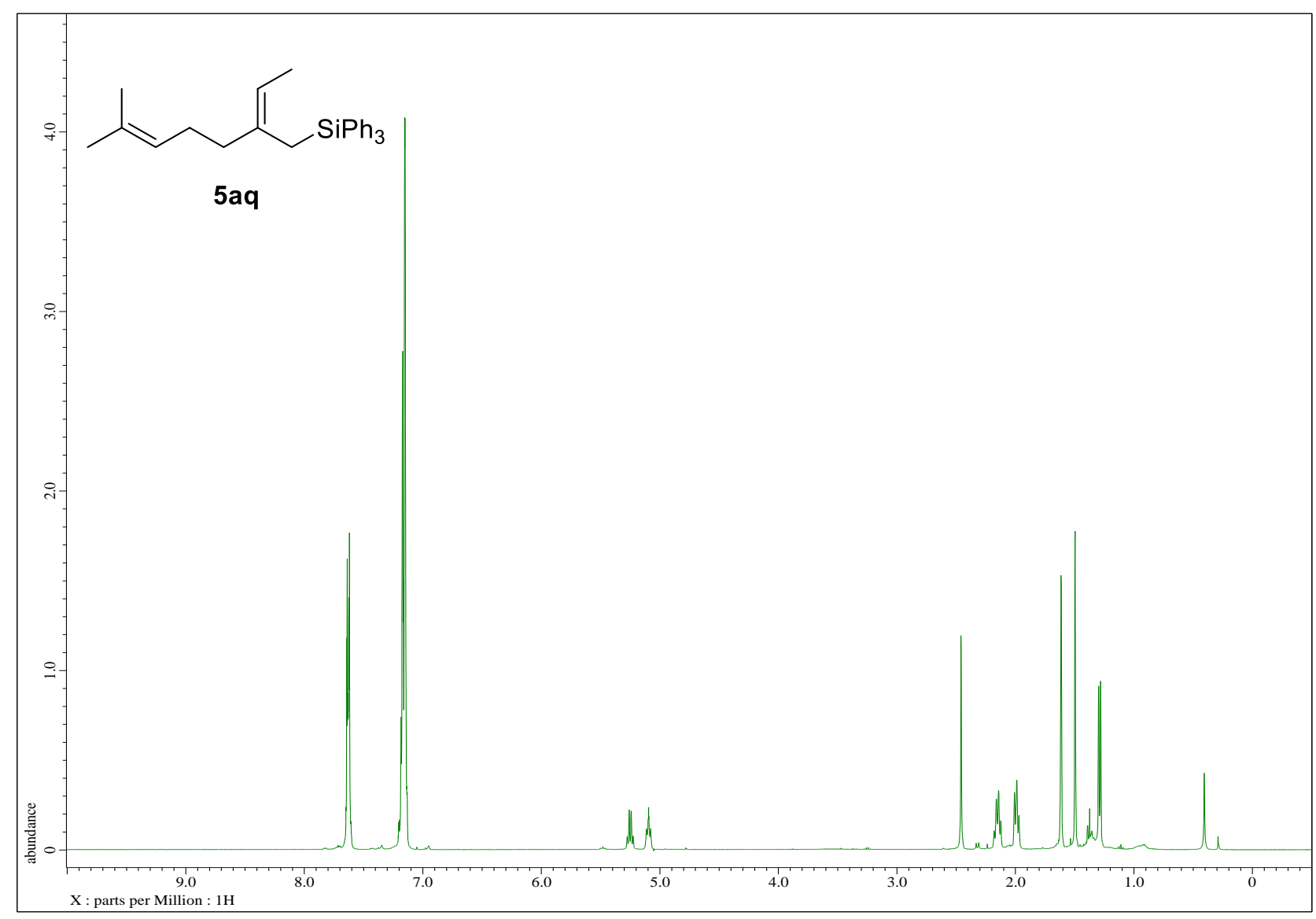

Figure S69. ${ }^{1} \mathrm{H}$ NMR spectra of (Z)-(2-ethylidene-6-methylhept-5-en-1-yl)triphenylsilane (5aq) in $\mathrm{CDCl}_{3}$

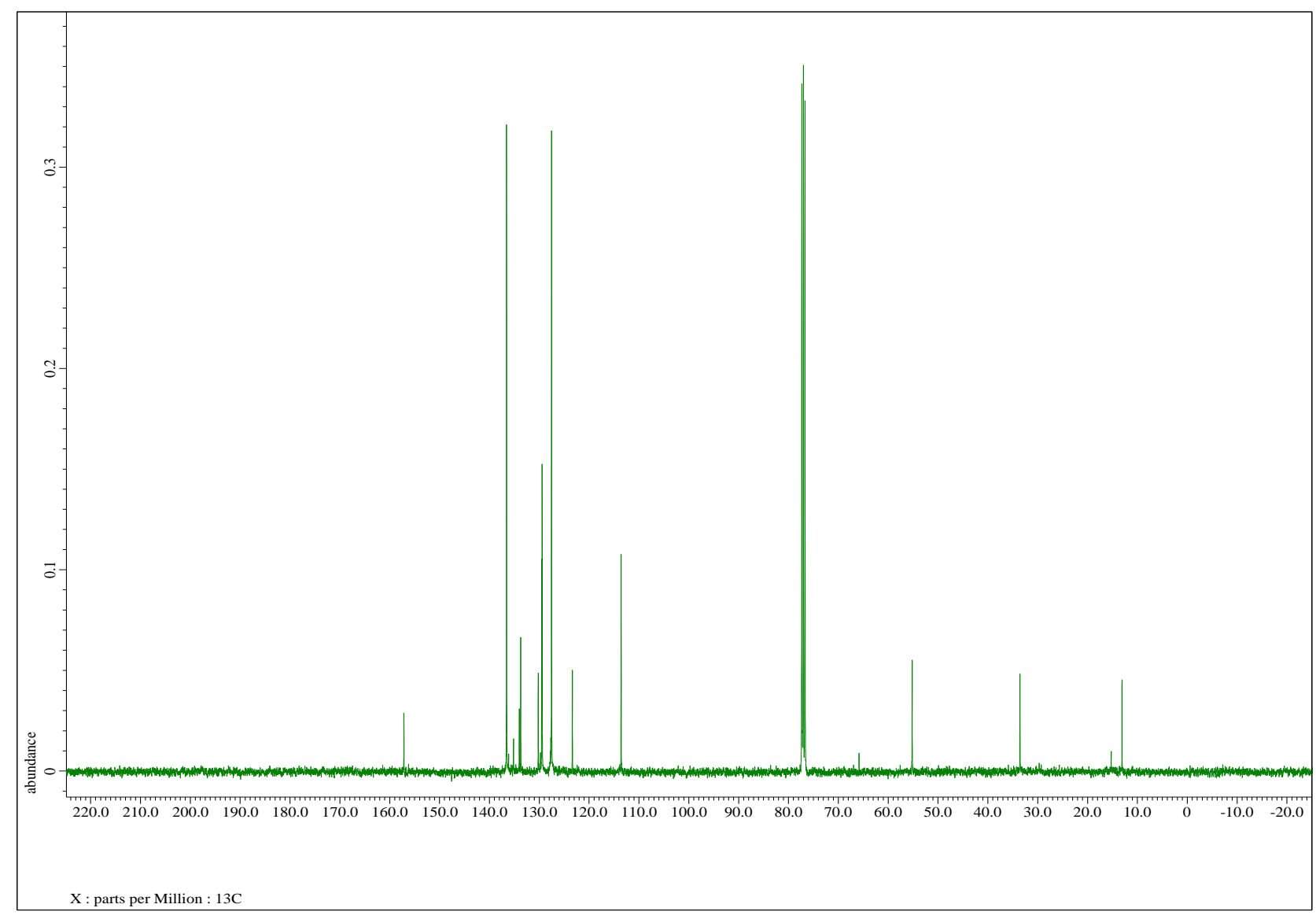

Figure S70. ${ }^{13} \mathrm{C}\left\{{ }^{1} \mathrm{H}\right\}$ NMR spectra of $(Z)$-(2-ethylidene-6-methylhept-5-en-1-yl)triphenylsilane (5aq) in $\mathrm{CDCl}_{3}$ 


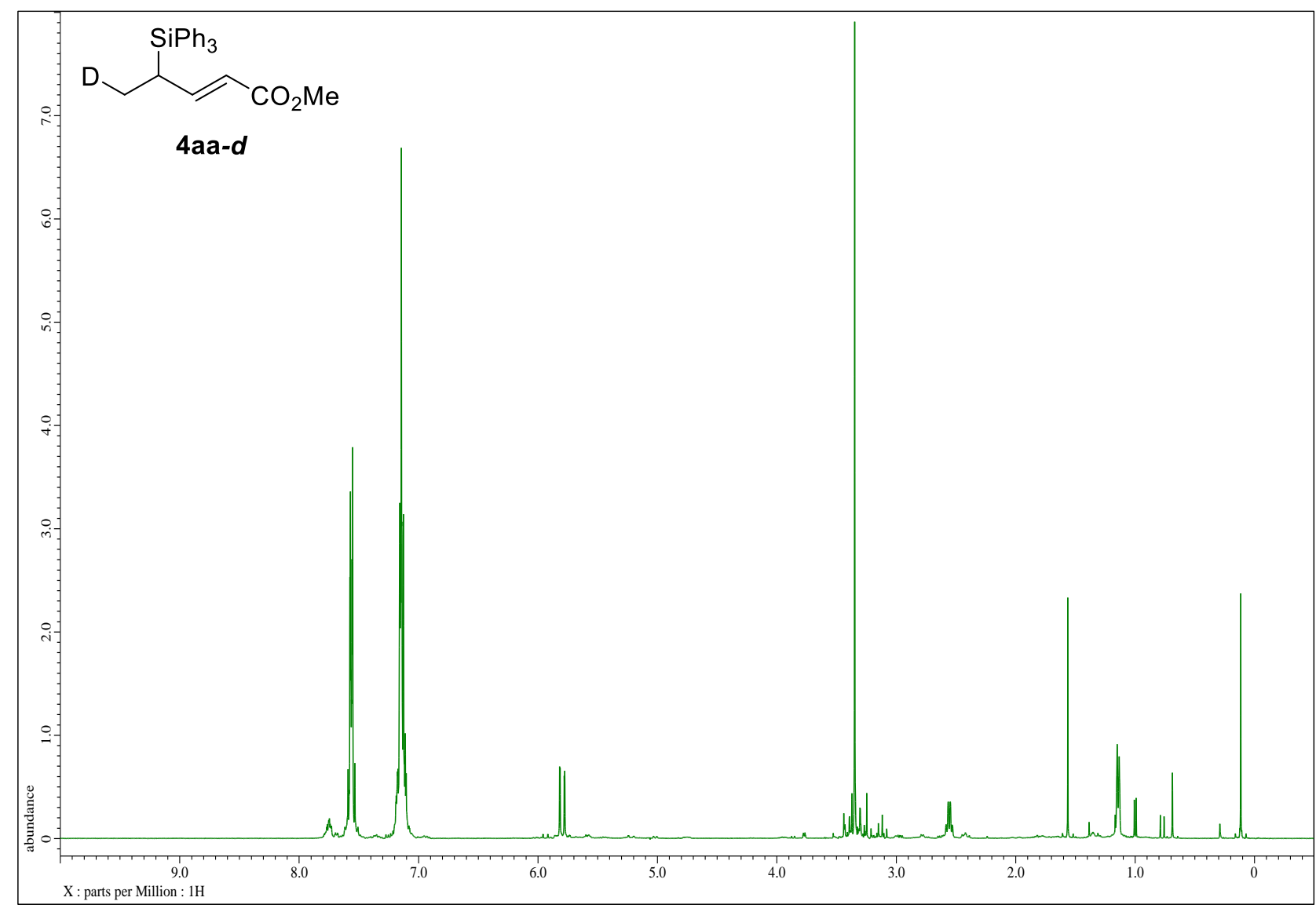

Figure S71. ${ }^{1} \mathrm{H}$ NMR spectra of methyl (E)-4-(triphenylsilyl)pent-2-enoate-5-d (4aa-d) in $\mathrm{C}_{6} \mathrm{D}_{6}$

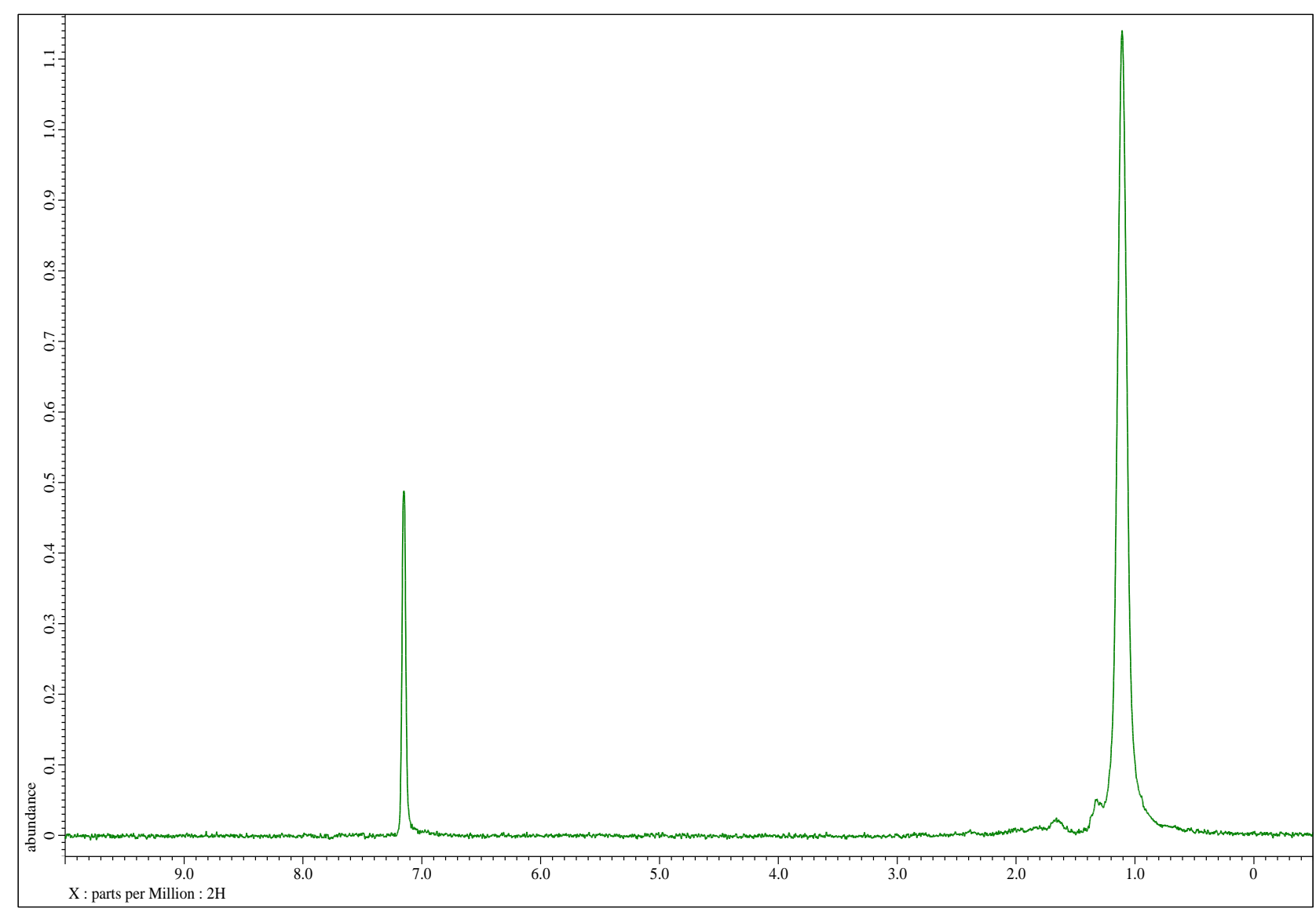

Figure S72. D NMR spectra of methyl (E)-4-(triphenylsilyl)pent-2-enoate-5- $d$ (4aa-d ) in $\mathrm{C}_{6} \mathrm{H}_{6}$ 


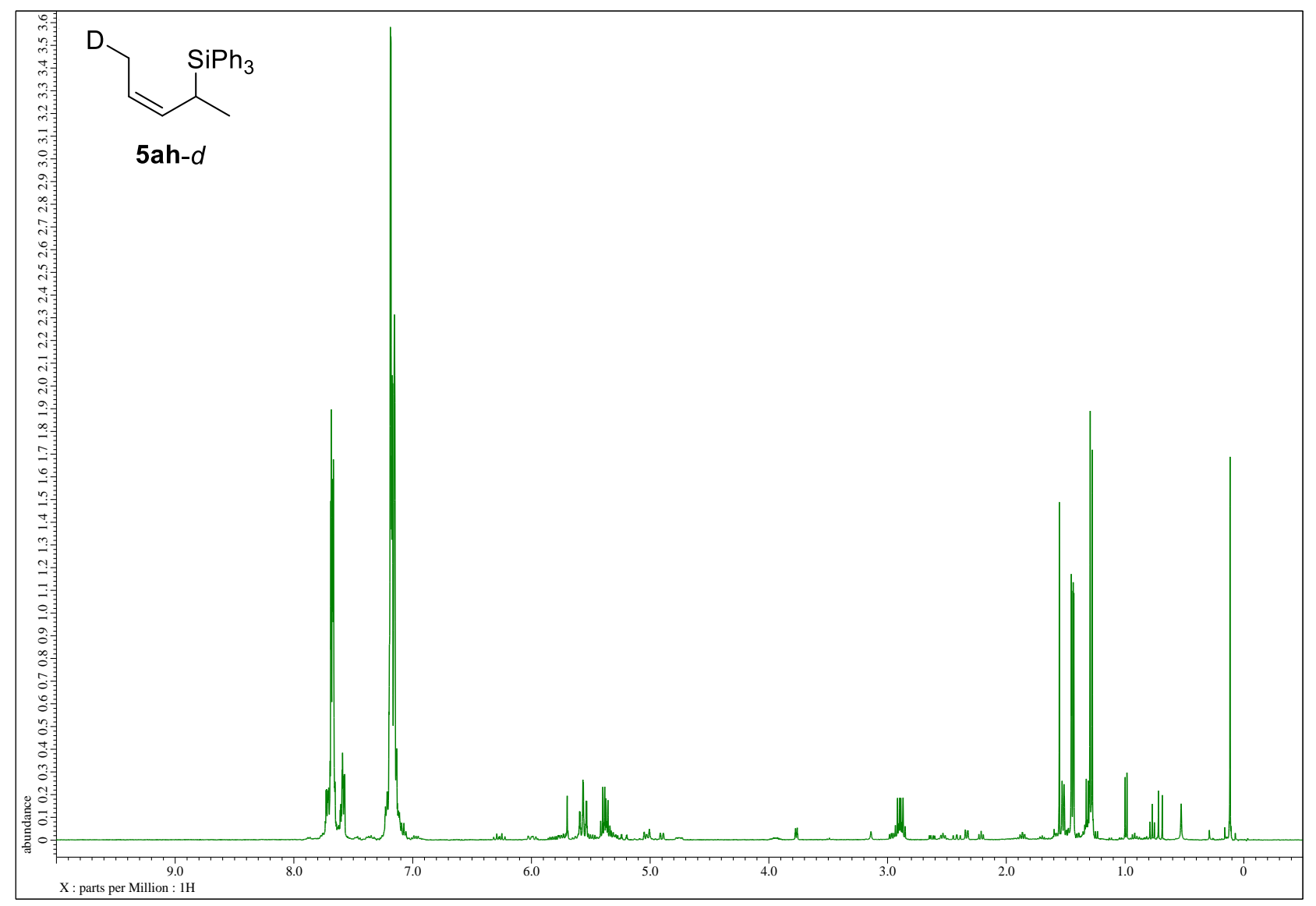

Figure S73. ${ }^{1} \mathrm{H}$ NMR spectra of (Z)-(pent-3-en-2-yl-5-d)triphenylsilane (5ah-d) in $\mathrm{C}_{6} \mathrm{D}_{6}$

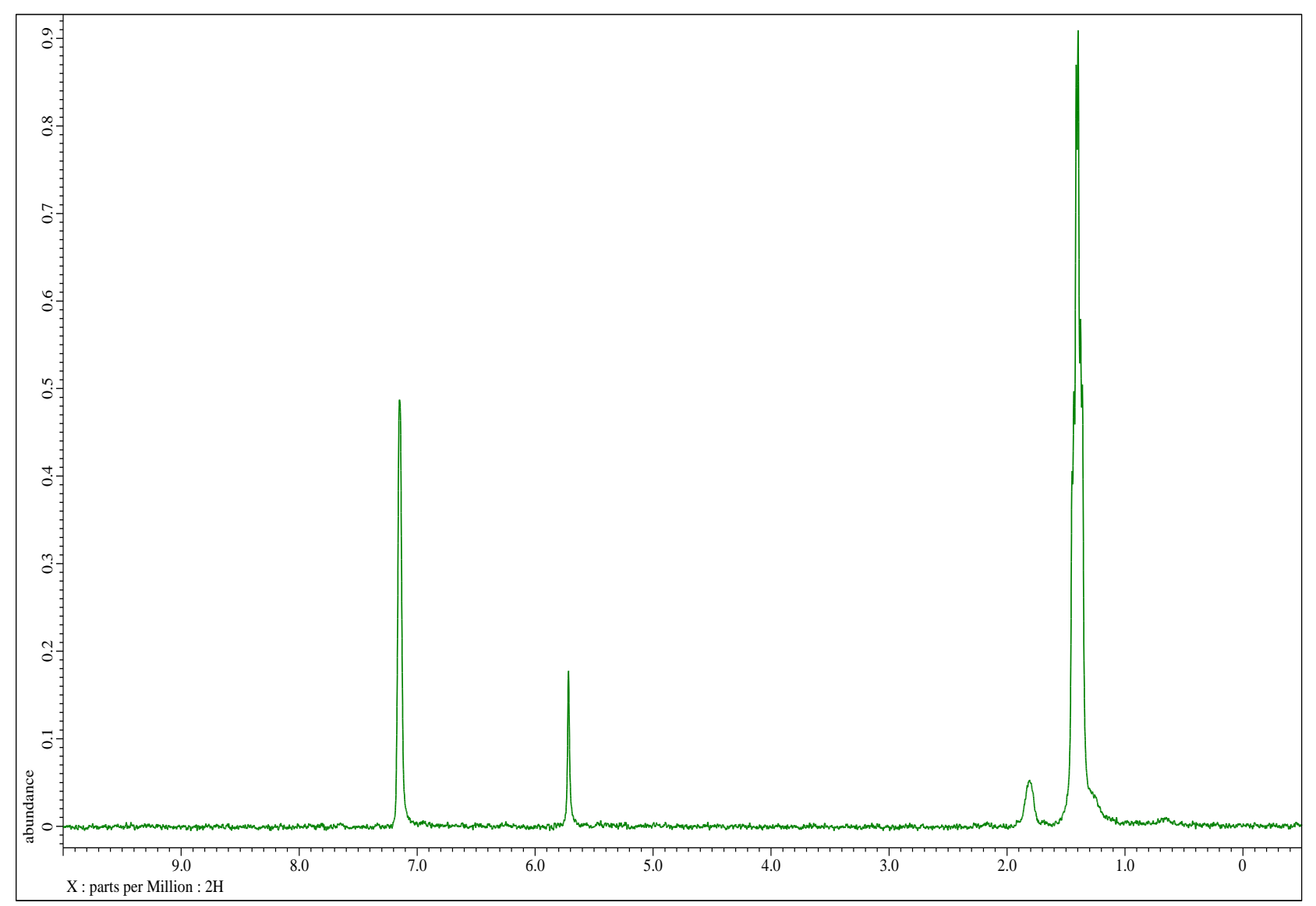

Figure S74. D NMR spectra of (Z)-(pent-3-en-2-yl-5-d)triphenylsilane (5ah-d) in $\mathrm{C}_{6} \mathrm{H}_{6}$ 